\title{
Argumentações matemáticas sob uma perspectiva crítica: uma análise de práticas didáticas no Ensino Fundamental
}

Valter Magalhães Costa

Dissertação apresentada ao

Instituto de Matemática e Estatística da

Universidade de São Paulo

para obtenção do título de Mestre em Ciências

no

Programa de Mestrado Profissional em Ensino de Matemática

Orientadora: Profa. Dra. Iole de Freitas Druck

São Paulo, outubro de 2017 


\title{
Argumentações matemáticas sob uma perspectiva crítica: uma análise de práticas didáticas no Ensino \\ Fundamental
}

\author{
Valter Magalhães Costa
}

Dissertação apresentada ao Programa de Mestrado Profissional em Ensino de Matemática do Instituto de Matemática e Estatística da Universidade de São Paulo para a obtenção do título de Mestre em Ciências. Esta versão contém as correções e alterações sugeridas pela Comissão Julgadora durante defesa pública ocorrida em 24/05/2017.

Comissão Julgadora

Prof. . Dr ${ }^{\mathrm{a}}$. Iole de Freitas Druck (Orientadora) - IME - USP.

Prof. ${ }^{a}$. Dr ${ }^{\mathrm{a}}$. Ana Paula Jahn - IME - USP.

Prof. . Dr ${ }^{\mathrm{a}}$, Lilian Nasser - UFRJ. 


\section{Agradecimentos}

À Profa. Dra. Iole Druck. Com sua orientação, dedicação e confiança, não apenas me ajudou a construir esta dissertação, como também, com seus ensinamentos e experiência, a me tornar um profissional mais confiante e seguro para prosseguir meu caminho no ensino de Matemática. Nesses anos de convivência, entendi, por meio de seus ensinamentos, que devo buscar a excelência pelos estudos e ser crítico de mim mesmo. Meus sinceros agradecimentos.

Agradeço às Profas. Dra. Ana Paula Jahn e Dra. Lilian Nasser, que por ocasião do exame de qualificação e da defesa desta dissertação, fizeram importantes comentários e críticas, contribuindo muito para o direcionamento e concretização desse trabalho. Agradeço também ao Professor Dr. Antonio José Lopes (Bigode), por ocasião da defesa dessa dissertação. O Professor contribuiu com muitos comentários importantes e que muito enriqueceram o presente trabalho. A todos esses professores, meus sinceros agradecimentos e digo que acolhi seus comentários e pedidos de correções com entusiasmo.

Dedico este trabalho à minha filha Laura, ao meu pai, Sr Manoel (in memoriam) e minha mãe, Dona Maria Santana. Agradeço a eles por tudo que sou hoje.

Por fim, agradeço a minha esposa, Elaine Maria, por sua paciência com a minha pessoa. Obrigado por fazer parte da minha vida. 


\section{Resumo}

Os documentos oficiais brasileiros enfatizam que a finalidade maior da Educação Básica é a formação integral do educando, com ênfase no pleno desenvolvimento da pessoa, preparo para o exercício da cidadania e qualificação para o trabalho. Nesta dissertação, discutimos o significado da formação integral do educando do ponto de vista da literatura existente e dos documentos normativos oficiais da Educação Básica brasileira. Buscamos entender e identificar metodologias sobre como o ensino de Matemática pode contribuir para a formação do educando. Entendemos que o senso crítico é uma modalidade de pensamento a ser desenvolvida na escola, por contribuir para a consecução daquelas finalidades. Nesse sentido, defendemos que atividades com argumentações precisam ser trabalhadas em sala de aula de Matemática, não apenas as que objetivam validar resultados puramente matemáticos, como também as que, utilizando ferramental matemático, validam afirmações em contextos extrínsecos a essa ciência. Por meio delas é que se manifesta o pensamento crítico. Com o objetivo de favorecer o desenvolvimento dessa modalidade de pensamento em salas de aula de $6^{\circ}$ e $7^{\circ}$ anos do Ensino Fundamental, desenvolvemos atividades didáticas envolvendo argumentações em e com Matemática. Para tanto, apoiamo-nos principalmente nas contribuições de Nicolas Balacheff sobre processos de prova e situações de validação, e de Ole Skovsmose e seus trabalhos sobre Educação Matemática Crítica, particularmente sua defesa da importância da proposição de cenários para investigação no trabalho escolar.

Palavras Chave: Senso Crítico; Argumentação; Validações Matemáticas; Cenários para investigações. 


\begin{abstract}
The official Brazilian documents emphasize that the main purpose of Basic Education is the integral formation of the student, with emphasis on: full development of the person, preparation for the exercise of citizenship and qualification for work. In this dissertation, we discuss the meaning of the Integral Formation of the student from the point of view of the existing literature and of the official normative documents on Brazilian Basic Education. We seek to understand and identify how mathematical teaching methodologies may contribute to the education of the student. We understand that critical sense, as a thinking modality, should be developed in school to contribute to the accomplishment of those aims. We argue that activities with arguments need to be worked out in the Mathematics classroom. Not only those that validate purely mathematical results but also the ones that, using mathematical tools, validate statements extrinsic to this science. Critical thinking manifests through them.

To favorize development of this kind of thinking in scholars of 6th and 7th grade, we applied didactic experiments involving arguments in and with Mathematics, based on contributions of Nicolas Balacheff and Ole Skovsmose. With respect to the first author, mainly on proof processes and validation situations and to the second, on his Critical Mathematical Education, specially about the importance of landscapes of investigations.
\end{abstract}

Key Words: Critical Sense; Arguments; Mathematical Validations; Landscapes of Investigations. 


\section{Sumário}

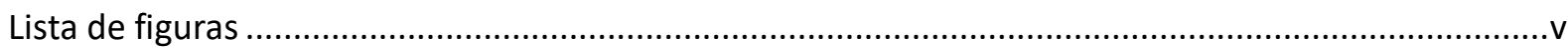

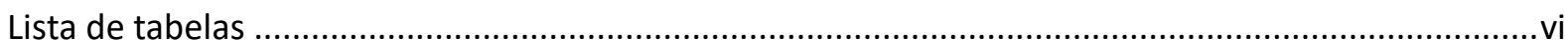

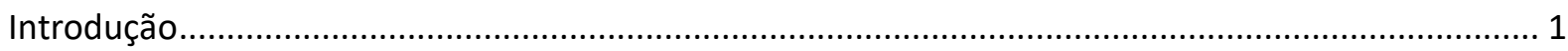

Capítulo I - Formação Integral do Educando....................................................................... 9

Capítulo II - Pleno Desenvolvimento, Cidadania e Senso Crítico ................................................. 17

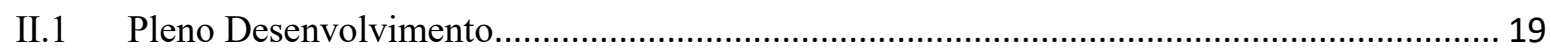

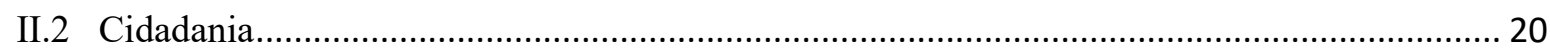

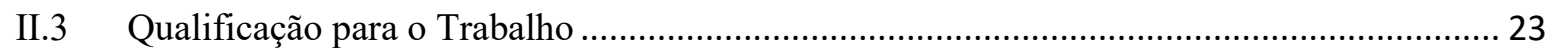

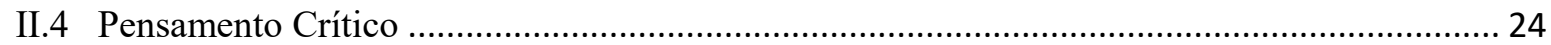

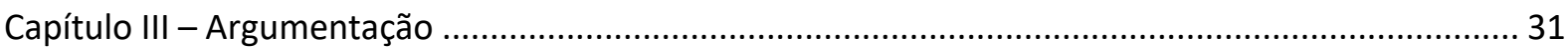

III.1 Argumentações Matemáticas ........................................................................... 34

Capítulo IV - Argumentações em Sala de Aula de Matemática da Educação Básica .......................... 41

IV.1 Ole Skovsmose, a Educação Matemática Crítica e Cenários para Investigação ................. 42

Educação Matemática Crítica - Pressupostos.................................................................... 42

A Ideologia da Certeza e o Poder Formatador da Matemática ................................................... 43

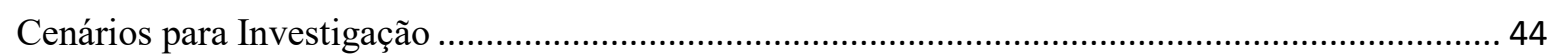

IV.2 Nicolas Balacheff e os diferentes tipos de validações matemáticas ................................... 49

IV.3 Dina e Pierre Van Hiele: sobre o Desenvolvimento do Pensamento Geométrico................ 60

Capítulo V - A Construção de Provas Geométricas à Luz dos Trabalhos de Balacheff e Van Hiele ..... 67 Capítulo VI - Sequência Didática em Geometria desenvolvida em uma turma de $6^{\circ}$ ano do Ensino

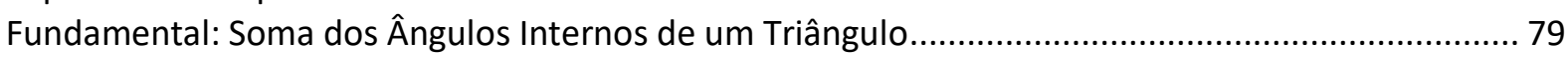

VI.I A Sequência Didática e sua $\quad$ Aplicação em Sala de Aula.................................................... 80

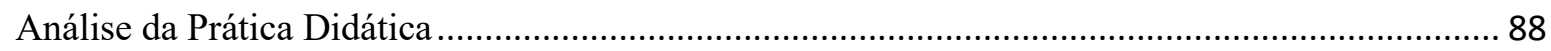

Capítulo VII - Sequência Didática envolvendo Grandezas Medidas e Análise Estatística de Dados em uma turma de 7ํ ano do Ensino Fundamental: a crise hídrica como cenário de investigação........... 95

VII.I A Sequência Didática e sua Aplicação em Sala de Aula............................................. 98

Análise da prática didática desenvolvida com o $7^{\circ}$ ano ................................................... 108

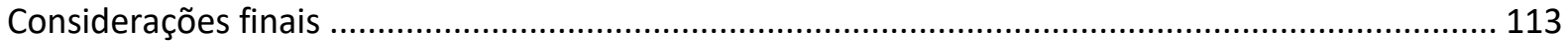

Referências Bibliográficas ........................................................................................ 121 


\section{Lista de figuras}

FIGURA 1 PROVA DA SOMA DOS ÂNGULOS INTERNOS DE UM TRIÂNGULO 52

FIGURA 2 PROVA DA SOMA DOS ÂNGULOS INTERNOS DE UM TRIÂNGULO PELO TEOREMA DAS PARALELAS .. 53 FIGURA 3 SOMA DOS N PRIMEIROS ÍMPARES NATURAIS. FONTE: BALACHEFF, 1988 ...................................54

FIGURA 4 PROVA PRAGMÁTICA PARA A SOMA DOS ÂNGULOS INTERNOS DE UM TRIÂNGULO .......................56

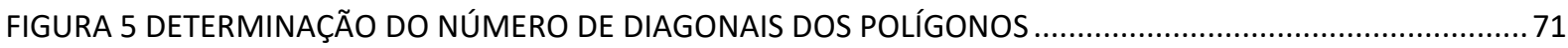

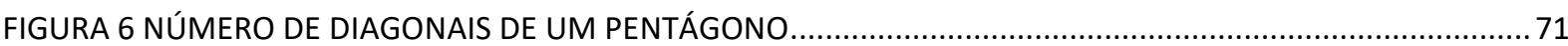

FIGURA 7 REFUTAÇÃO PARA O MÉTODO UTILIZADO PELOS ALUNOS PARA COMPARAR ÂNGULOS UTILIZANDO RÉGUA. .82

FIGURA 8 IDENTIFICAÇÃO E DETERMINAÇÃO DO SEGMENTO DE MENOR COMPRIMENTO QUE UNE O VÉRTICE A AO LADO BC .85

FIGURA 9. DETERMINAÇÃO E IDENTIFICAÇÃO DA ALTURA DO TRIÂNGULO COMO O SEGUIMENTO DE MENOR COMPRIMENTO QUE UNE O VÉRTICE A AO LADO BC. .86 FIGURA 10 PROVA DE QUE A SOMA DOS ÂNGULOS INTERNOS DO TRIÂNGULO É 180…...... 


\section{Lista de tabelas}

TABELA 1 AMBIENTES DE INVESTIGAÇÃO. FONTE: UM CONVITE À EDUCAÇÃO MATEMÁTICA CRÍTICA

(SKOVSMOSE, 2014)... .47

TABELA 2 TEMPOS DE BANHO DE FAMILIARES DE ALUNO DO 6 DO E.F. .96 TABELA 3 TEMPOS DE BANHOS DE ALUNOS DO 60 DO E.F. EM UMA SEMANA TÍPICA. OBS: (***) INDICA QUE O VALOR NÃO FOI AFERIDO NESSE DIA.. 101 TABELA 4 TEMPOS DE BANHOS E RESUMO COMPARATIVO DE GASTO DE FAMILIARES DO ALUNO 1. 104 TABELA 5 TEMPOS DE BANHOS E RESUMO COMPARATIVO DE GASTO DE FAMILIARES DO ALUNO 2. 104 TABELA 6 TEMPOS DE BANHOS E RESUMO COMPARATIVO DE GASTO DE FAMILIARES DO ALUNO 3. 105 TABELA 7 TEMPOS DE BANHOS E RESUMO COMPARATIVO DE GASTO DE FAMILIARES DO ALUNO 4. 105 TABELA 8 TEMPOS DE BANHOS E RESUMO COMPARATIVO DE GASTO DE FAMILIARES DO ALUNO 5. 106 TABELA 9 TEMPOS DE BANHOS E RESUMO COMPARATIVO DE GASTO DE FAMILIARES DO ALUNO 6. 106 


\section{Introdução}

Nos diversos componentes curriculares que compõem as áreas de conhecimento de Linguagens e Ciências humanas, parece não haver dúvidas sobre como favorecer o desenvolvimento das capacidades de bem argumentar e de senso crítico nos educandos. Nesses ambientes, são muitas as discussões que podem ser promovidas em sala de aula, nas quais professores e alunos são envolvidos em debates críticos, fornecendo argumentos para sustentar suas posições. Tudo isso é facilitado nos componentes dessas áreas, pois a gama de assuntos polêmicos que aparecem em diversas mídias os torna de conhecimento da maioria dos estudantes. Cabe ainda destacar que, observados os objetos de estudo próprios a cada disciplina, métodos de pesquisa, etc., a comunicação se faz utilizando a língua materna, sem haver necessidade da utilização de simbologias especiais, como é o caso da Matemática.

Dessa forma, considerando que o senso crítico, no contexto de um debate, é uma habilidade que se manifesta na produção, análise e avaliação de argumentos, e que faz parte da atividade matemática construir validações (provas ou refutações) de afirmações dentro de seu contexto, surge a pergunta: como trabalhar ou aplicar atividades significativas em sala para favorecer o desenvolvimento do pensamento crítico dos estudantes? Tanto nas Ciências Humanas e nas Linguagens, quanto em Matemática, fornecer argumentos com justificativas para as afirmações enunciadas é algo de bastante importância, pois muitas vezes cometemos erros no processo de inferência, obtendo conclusões que não decorrem das informações disponíveis. Assim, nossa hipótese é que um trabalho em sala de aula com validações também pode contribuir para o desenvolvimento do senso crítico do educando.

Em Matemática, as validações são compostas de argumentos e, nesse contexto, as afirmações são sustentadas ou refutadas, respectivamente, por meio da exibição de demonstrações ou contraexemplos. Para os matemáticos profissionais, provas ou validações de proposições devem ser corretas do ponto de vista da Lógica, como garantia da consistência do conhecimento matemático, e fornecer o argumento final sobre a veracidade ou não da assertiva em foco. O matemático profissional faz uso do método axiomático e do raciocínio lógico dedutivo. Sem adentrarmos em detalhes, o método axiomático consiste na adoção de noções primitivas, de suas propriedades básicas e de relações fundamentais entre elas, sobre as quais são construídos os demais resultados matemáticos. Já a utilização do raciocínio lógico dedutivo para validação de resultados consiste em estabelecer conclusões coerentes a partir de dados ou informações isentas de abusos ou erros relativamente às leis da Lógica Clássica. Para tanto, 
utiliza-se de uma linguagem sintética, visando eliminar ambiguidades ou as múltiplas interpretações de termos presentes na língua materna.

Os raciocínios que justificam uma afirmação são expressos por meio de argumentações, ou seja, situações de interação (oral ou escrita) que explicitam as razões das conclusões estabelecidas (De VILLIERS, 1999). O objetivo principal de um argumento é fornecer elementos que validem sua veracidade. Deve-se observar, em um processo argumentativo, se as sentenças utilizadas estão conectadas de forma coerente entre si e com a conclusão. Portanto, apesar de mesmo implicitamente o raciocínio lógico estar presente sempre que se faz uso de argumentações, ele não é a única modalidade de pensamento que contribui para efetivar uma validação. Podemos citar um exemplo de Mortari (2001, p. 4), mostrando a importância de notar que muitas vezes raciocinamos a partir de hipóteses sem o uso explícito de regras da Lógica: você pode estar interessado em saber o que acontecerá se você comprar agora o DVD player dos seus sonhos. Raciocinando a partir daí, e com conhecimento do estado de seu bolso, você pode chegar à conclusão de que vai faltar dinheiro para o aluguel. O resultado do processo, nesse caso, não é que você fique sabendo que não há dinheiro para o aluguel, mas que isso irá acontecer se você comprar o DVD player. O conhecimento novo que você obteve, no caso, é que existe certa conexão entre comprar o aparelho e não poder pagar o aluguel

Assim, em muitas situações em que se deseja avaliar uma afirmação, além do raciocínio lógico dedutivo, outros tipos de raciocínios podem ser utilizados para validar resultados em seus contextos, como o pensamento indutivo, o raciocínio ou visão geométrico-espacial e o pensamento não determinístico ou estatístico. Tendo em vista os diversos tipos de raciocínios matemáticos, discutimos aqui algumas práticas com argumentações matemáticas que podem favorecer o desenvolvimento do senso crítico do educando.

A Constituição Federal (1988) e os documentos oficiais que tratam da Educação Básica como a Lei de Diretrizes e Bases da Educação Nacional (BRASIL, 1996), assim como, mais recentemente, as Diretrizes Curriculares Nacionais da Educação Básica (BRASIL, 2013), conferem à Educação Básica o meio que garante ao educando exercer em plenitude o direito à cidadania. Ainda, segundo Luckesi (2011, p. 37), nesse nível escolar, o objetivo da prática educativa é oferecer ao educando condições de aprendizagem e desenvolvimento, com vistas à sua formação como indivíduo e cidadão. De forma mais geral, desde a Constituição Federal de 1988, são finalidades da Educação Básica o pleno desenvolvimento do educando, seu preparo para o exercício da cidadania e sua qualificação para o trabalho. Nesta dissertação, com a expressão "Formação Integral do Educando" englobamos o conjunto dessas três finalidades. 
Ao explorar o significado dessas finalidades, entendemos que o desenvolvimento do Senso Crítico é imprescindível na formação do educando, pois a apropriação dessa modalidade de pensamento promove o desenvolvimento da consciência das responsabilidades e direitos inerentes à vida em sociedade e bagagem pessoal adequada para intervenções autônomas em práticas sociais e nas relações de trabalho. Como o pensamento crítico exterioriza-se na exposição de argumentações bem fundamentadas, destacamos aqui o papel dos diversos tipos de raciocínios na análise e construção de argumentos para a consecução de tais finalidades. Com isso, buscamos contribuir para a formação integral expressa nos documentos oficiais.

Em particular, temos por objetivo examinar como argumentos presentes no dia a dia das pessoas e como conhecimentos dos diversos tipos de raciocínios podem ser empregados para validarem ou refutarem afirmações em diversos contextos. Outro objetivo é fazer uma reflexão teórica sobre Argumentação, com base na literatura estudada, notadamente Balacheff, Carraher, Skovsmose e Van Hiele (BALACHEFF, 1987, 1988; CARRAHER, 2011; SKOVSMOSE, 2012, 2013, 2014 e CROWLEY, 1994). Além do detalhamento teórico, outro propósito deste trabalho é a produção de atividades didáticas com a finalidade de explorar processos de validações e argumentações com alunos de $6^{\circ}$ e $7^{\circ}$ anos do Ensino Fundamental da escola pública.

Em resumo, desenvolvemos este trabalho a partir das questões motivadoras e objetivos seguintes:

\section{QUESTÕES MOTIVADORAS}

1) Tendo em vista que o senso crítico é uma capacidade importante na atuação consciente dos cidadãos na sociedade, surgem as questões: O que é senso crítico? Que papel o ensino de Matemática na Educação Básica pode representar no desenvolvimento de senso crítico e da capacidade de argumentação dos educandos?

2) Tendo em vista que o trabalho investigativo do matemático profissional se caracteriza por resolver problemas, sendo essencial o levantamento de hipóteses, questionamentos, análises de erros, argumentações e validações, a pergunta que se segue é: como essa metodologia, utilizada na construção dessa Ciência, pode ser empregada em sala de aula do Ensino Fundamental, no sentido de contribuir para o desenvolvimento do senso crítico e das habilidades típicas do trabalho do matemático profissional listadas?

3) Tendo em vista que os conhecimentos matemáticos são necessários para muitas tomadas de decisões no cotidiano e nas diversas práticas sociais, como favorecer em sala de aula de 
Matemática do Ensino Fundamental o desenvolvimento das capacidades de argumentar e validar conclusões na articulação daquela ciência com questões sociais relevantes no exercício da cidadania?

\section{OBJETIVOS}

1) Fazer um levantamento sobre o que a legislação e autores definem acerca da formação integral do educando.

2) Pesquisar o embasamento teórico adequado que possibilite um aprofundamento tanto sobre os significados de senso crítico e de argumentação quanto a respeito de reflexões sobre práticas educacionais voltadas ao desenvolvimento de tais capacidades em sala de aula de Matemática na Educação Básica. Particularmente estudar os trabalhos de Ole Skovsmose, Nicolas Balacheff e Pierre Marie Van Hiele.

3) Elaborar propostas de atividades, aplicar com nossos alunos de $6^{\circ}$ e de $7^{\circ}$ anos da Escola Estadual Domingos Mignoni e analisar as sequências didáticas desenvolvidas, com vistas a investigar e aprofundar a reflexão sobre as questões 2 e 3.

Com referência às questões acima citadas e visando respondê-las, organizamos esta dissertação conforme a descrição a seguir.

No Capítulo I, descrevemos o que diz a legislação sobre as finalidades da Educação Básica no Brasil e sobre a função dos sistemas educativos. Discutimos ainda qual o papel do ensino e a função da escola à luz de autores como Dewey (1959), Skovsmose (1998) e Zabala (2002). Por fim, englobamos sob o rótulo "Formação Integral" as três finalidades da Educação Básica (Pleno Desenvolvimento, Cidadania e Qualificação para o Trabalho) previstas na Constituição Federal. São esses três aspectos da Formação Integral que discutimos no capítulo seguinte, explicitando nossa compreensão sobre como o desenvolvimento do senso crítico e da capacidade de argumentação contribuem para tais finalidades.

No Capítulo II, fazemos um aprofundamento teórico baseado na visão de autores como David Carraher (2011), Nilson José Machado (1997), entre outros, não necessariamente nesta ordem, sobre Pleno Desenvolvimento, Cidadania, Qualificação para o trabalho e Senso Crítico. Elementos esses que são abordados repetidamente na legislação brasileira que trata da Educação Básica. Neste capítulo, buscamos aprofundar o entendimento sobre o que é dito nas resoluções oficiais a partir da literatura aqui utilizada, explicitando justificativas da importância 
desses pontos para a formação do educando. Nele também exploramos a relação entre o desenvolvimento do Senso Crítico e a formação integral do educando.

No Capítulo III tratamos especificamente de argumentação. Inicialmente, estruturamos o que é um processo argumentativo. À luz de autores como Paulo Freire (1996, 1999, 2005), entendemos qual o seu papel na construção das diversas Ciências e, em consonância com o Pedagogo, discutimos como a prática argumentativa em sala de aula pode contribuir para a consecução das finalidades da Educação Básica citadas no Capítulo I. Encerramos esse capítulo tratando, em particular, do papel das argumentações matemáticas, ou seja, daqueles argumentos que validam conhecimentos propriamente matemáticos e aqueles que fazem uso de seu ferramental (linguagem, métodos, teorias, etc) para validar conhecimentos em outros contextos. Nesse sentido, fazemos a diferenciação entre Argumentos em Matemática e Argumentos com Matemática, respectivamente, na abordagem de práticas argumentativas em sala de aula de Matemática.

No Capítulo IV, fazemos uma discussão mais aprofundada sobre as argumentações matemáticas em sala de aula à luz de Skovsmose (1998, 2000), Balacheff (1987) e Crowley (1994). Skovsmose (2000) propõe que o ensino de Matemática se dê em ambientes de investigação. Com o conceito de cenários para investigação Skovsmose propõe ambientes de investigações em três contextos matemáticos (SKOVSMOSE 2014, p. 54), para que seja proporcionado aos estudantes um amplo espaço propício à prática argumentativa. Balacheff (1987) faz a diferenciação entre as validações aceitas pelos matemáticos (demonstrações) e aquelas utilizadas para convencer e que devem ser trabalhadas em sala de aula (provas). Um aspecto interessante do trabalho desse autor e que destacamos nessa dissertação, são os conceitos de provas pragmáticas e conceituais. Para o autor, as construções desses tipos de provas convencem o aluno sobre a veracidade do fato que se deseja validar e refletem o nível de maturidade do aluno no que se refere a sua apropriação do caráter geral da situação. Já Van Hiele (CROWLEY, 1994) diz que, em Geometria, para o aluno construir deduções formais é necessário passar por níveis mais elementares do pensamento geométrico. Para o autor, o desenvolvimento do pensamento geométrico ocorre quando o aluno percorre níveis sequenciais até o nível das deduções. Esse último sendo o rigor utilizado pelos matemáticos. Como metodologia de favorecimento de percurso para o desenvolvimento do pensamento geométrico, o autor propõe cinco fases de aprendizado, também sequenciais: interrogação, orientação dirigida, explicação, orientação livre e integração.

No Capítulo V, relacionamos as ideias aqui expostas de Van Hiele (CROWLEY, 1994) e Balacheff $(1987,1988)$. Entendemos que para os dois autores, no que se refere à elaboração 
de provas, o aluno evolui em maturidade à medida que consegue perceber o caráter geral de uma situação. Para Balacheff (1988), intervenções específicas do professor podem favorecer a progressão do aluno em direção à exibição de uma prova mais geral. Além disso, a evolução das provas pragmáticas (empirismo ingênuo e experimento crucial) até as provas conceituais (exemplo genérico e experimento reflexivo), ao mesmo tempo depende e exibe o nível de maturidade do aluno no momento da explicitação de suas provas. Assim, nossa hipótese é que os trabalhos de Balacheff e de Van Hiele podem ser relacionados, pois ambos preveem que deve haver uma evolução das concepções dos educandos até conseguirem construir provas cada vez mais gerais, culminando no pensamento dedutivo. E, além disso, também consideramos que um trabalho com provas pragmáticas pode constituir-se em um método para que o aluno caminhe pelos níveis de Van Hiele, ao longo das fases de aprendizado que orientam o progresso da aprendizagem dos estudantes no interior de cada nível.

No Capítulo VI, descrevemos uma sequência didática em sala de aula de $6^{\circ}$ ano do Ensino Fundamental, que classificamos aqui como um trabalho com "argumentações em Matemática". Os alunos exercitaram a construção de uma validação de um resultado matemático utilizando argumentações e refutações em um cenário para investigação em Geometria. Começando com a observação de elementos básicos dos triângulos - vértices, ângulos, medidas dos lados, altura e algumas propriedades - construímos relações que culminaram na prova que a soma das medidas dos ângulos internos de qualquer triângulo é $180^{\circ}$. Procuramos que os alunos desenvolvessem senso crítico por meio da utilização de argumentos e refutações. O primeiro ponto foi verificar como podemos, simultaneamente, trabalhar linguagem, conceitos, propriedades geométricas e desenvolver a competência argumentativa nos alunos. O segundo ponto foi propiciar um espaço de discussão visando a construção de uma prova matemática em sala de aula, em oposição ao tradicional "fornecimento" de resultados matemáticos prontos e sem explicação.

No Capítulo VII, desenvolvemos outra sequência didática com alunos de $7^{\circ}$ Ano com o objetivo de explorar conteúdos pertinentes às áreas de Grandezas e Medidas e Análise Estatística de dados. O cenário para investigação foi o contexto da crise hídrica pela qual passou o Estado de São Paulo no ano de 2015 e o objetivo foi fazer com que os alunos tomassem consciência do quanto seu consumo individual e dos outros membros de sua família oneravam o consumo mensal familiar. Novamente, por meio de argumentações e refutações os alunos puderam questionar afirmações provenientes da mídia e questões relativas ao senso comum sobre o alto consumo hídrico da população. Mostramos, nesse caso, que o raciocínio estatístico, além do raciocínio lógico, era necessário para estabelecer um julgamento das afirmações, pois 
as conclusões dos alunos foram conseguidas por meio de pesquisas na internet e da análise de dados por eles coletados.

No Capítulo VIII, das considerações finais, fazemos uma avaliação sobre em que sentido acreditamos que este nosso trabalho possa representar uma contribuição para um entendimento mais aprofundados das questões motivadoras colocadas e explicitamos nossas conclusões. 


\section{Capítulo I - Formação Integral do Educando O que dizem sobre o tema as leis brasileiras sobre a Educação Básica}

Atualmente, os homens associam-se com as mais diversas finalidades e modos: associações sindicais, culturais, científicas, políticas e religiosas e, dentre essas, numerosas subdivisões, como partidos com diferentes aspirações políticas, seitas religiosas, corporações, sociedades comerciais e civis, etc. E, como em qualquer sociedade consolidada, na qual os integrantes compartilham dos mesmos objetivos, crenças, aspirações, conhecimentos etc., a atividade de um indivíduo está associada às exigências, aprovação ou reprovação dos demais (DEWEY, 1959, pp 6,7). No que se refere à sociedade brasileira como um todo, a Constituição Federal de 1988 é o conjunto de normas que regula o Estado Brasileiro.

A Constituição Federal (BRASIL, 1988), conforme consta em seu art. $1^{\circ}$, tem como fundamentos para construção da nação "a soberania, a cidadania, a dignidade da pessoa humana e os valores sociais do trabalho e da livre iniciativa". No seu art. $3^{\circ}$, são estabelecidos objetivos a serem atingidos pela sociedade brasileira, a saber, "construir uma sociedade livre, justa e solidária, garantir o desenvolvimento nacional, erradicar a pobreza e a marginalização, reduzir as desigualdades sociais e regionais, promover o bem de todos, sem preconceitos de origem, raça, sexo, cor, idade e quaisquer outras formas de discriminação". Nela também são estabelecidas normas, funções, competências e relações entre os diferentes órgãos e poderes, responsabilidades do poder público para que se cumpram esses objetivos. A Educação exerce um papel fundamental para tanto na carta magna, onde, em seu art. $6^{\circ}$, é tratada como um direito social, sendo um alicerce fundamental para se garantir o cumprimento daqueles objetivos. Conforme o artigo 205": Art. 205, "a educação, direito de todos e dever do Estado e da família, será promovida e incentivada com a colaboração da sociedade, visando ao pleno desenvolvimento da pessoa, seu preparo para o exercício da cidadania e sua qualificação para o trabalho”. (BRASIL, 1988)

Em consonância com a Constituição Federal, na Lei de Diretrizes e Bases da Educação Nacional (BRASIL, 1996), em seu art. 2º́ é ressaltada a Educação Básica como direito universal e sua promoção como mecanismo fundamental para a garantia do "pleno desenvolvimento do educando, seu preparo para o exercício da cidadania e sua qualificação para o trabalho". Sobre o real sentido do verbo “educar", vale ainda citar Zabala (2002, p. 21), que diz ser uma ação que contribui para o desenvolvimento da pessoa como ser global, ou seja, capaz de atuar e responder a todos os problemas que a vida em sociedade lhe apresenta. Partindo 
de tais fundamentos, neste trabalho utilizamos a expressão "Formação Integral do Educando" para abranger, em conjunto, as três finalidades primordiais da Educação Básica Brasileira anteriormente citadas e discutimos possibilidades de trabalhos em sala de aula de Matemática que concorram para a consecução das mesmas.

Etimologicamente, educar significa "dirigir ou elevar". De forma resumida podemos dizer que a Educação, como função social da escola e do sistema educativo como um todo, deve promover uma formação global que permita ao indivíduo atuar em ambientes que transcendam o espaço e tempo escolares e o grupo social em que está inserido. Deve também atender às diferentes demandas sociais e às exigências de um mundo em constante evolução, constituindo, dessa forma, um degrau para o acolhimento de valores, saberes, hábitos culturais e aspirações dos estudantes (LIBÂNEO, 2012, p. 63; ZABALA, 2002, p. 43).

Assim, visando uma educação que atenda aos diversos interesses individuais, bem como aos diversos grupos sociais, o desafio é garantir, de forma contextualizada, o direito humano universal e individual à educação. Atendendo a esses propósitos, segundo as Diretrizes Curriculares Nacionais Gerais para a Educação Básica - DCNGEB (BRASIL, 2013, pp. 6379), os seguintes princípios sustentam o projeto de educação nacional:

\footnotetext{
Art. $4^{\circ}$ : As bases que dão sustentação ao projeto nacional de educação responsabilizam o poder público, a família, a sociedade e a escola pela garantia a todos os educandos de um ensino ministrado de acordo com os princípios de:

I - igualdade de condições para o acesso, inclusão, permanência e sucesso na escola; II - liberdade de aprender, ensinar, pesquisar e divulgar a cultura, o pensamento, a arte e o saber;

III - pluralismo de ideias e de concepções pedagógicas;

IV - respeito à liberdade e aos direitos;

$\mathrm{V}$ - coexistência de instituições públicas e privadas de ensino;

VI - gratuidade do ensino público em estabelecimentos oficiais;

VII - valorização do profissional da educação escolar;

VIII - a gestão democrática do ensino público, na forma da legislação e normas dos sistemas de ensino;

IX - a garantia de padrão de qualidade;

$\mathrm{X}$ - a valorização da experiência extraescolar;

XI - vinculação entre a educação escolar, o trabalho e as práticas sociais

(BRASIL, 2013, p.64)
}

Nas Diretrizes específicas para as etapas da Educação Básica são retomados e aprofundados tais princípios e finalidades. Assim, por exemplo, além da preparação para a cidadania, a importância do desenvolvimento de senso crítico aparece explicitamente nas Diretrizes Curriculares Nacionais para o Ensino Fundamental de 9 anos - DCNEF (BRASIL, 2013, pp. 130-142) - e nas Diretrizes Curriculares Nacionais para o Ensino Médio - DCNEM (BRASIL, 2013, pp. 194-201). Sobre sistemas de ensino e propostas curriculares, os artigos $6^{\circ}$ 
e $7^{\circ}$ das DCNEF, em suas alíneas II e III, especificam (com destaques nossos, em negrito, aos pontos que discutimos nesta dissertação):

Art. $6^{\circ}$ Os sistemas de ensino e as escolas adotarão como norteadores das políticas educativas e das ações pedagógicas, os seguintes princípios:

$[.$.

II - Políticos: de reconhecimento dos direitos e deveres de cidadania, de respeito ao bem comum e à preservação do regime democrático e dos recursos ambientais; da busca da equidade no acesso à educação, à saúde, ao trabalho, aos bens culturais e outros benefícios; da exigência de diversidade de tratamento para assegurar a igualdade de direitos entre os alunos que apresentam diferentes necessidades; da redução da pobreza e das desigualdades sociais e regionais;

$[\ldots]$

Art. $7^{\circ}$ De acordo com esses princípios, e em conformidade com o art. 22 e o art. 32 da Lei n ${ }^{\circ}$ 9.394/96 (BRASIL, 1996), as propostas curriculares do Ensino Fundamental visarão desenvolver o educando, assegurar-lhe a formação comum indispensável para o exercício da cidadania e fornecer-lhe os meios para progredir no trabalho e em estudos posteriores, mediante os objetivos previstos para esta etapa da escolarização, a saber:

$[\ldots]$

II - a aquisição de conhecimentos e habilidades, e a formação de atitudes e valores como instrumentos para uma visão crítica do mundo;

[...] (BRASIL, 2013, p. 131)

$\mathrm{O}$ artigo $4^{\circ}$ da DCNEM dispõe (onde, novamente, os destaques são nossos):

Art. $4^{\circ}$ As unidades escolares que ministram esta etapa da Educação Básica devem estruturar seus projetos político-pedagógicos considerando as finalidades previstas na Lei $n^{\circ}$ 9.394/96 (Lei de Diretrizes e Bases da Educação Nacional):

I - a consolidação e o aprofundamento dos conhecimentos adquiridos no Ensino Fundamental, possibilitando o prosseguimento de estudos;

II - a preparação básica para o trabalho e a cidadania do educando para continuar aprendendo, de modo a ser capaz de se adaptar a novas condições de ocupação ou aperfeiçoamento posteriores;

III - o aprimoramento do educando como pessoa humana, incluindo a formação ética e o desenvolvimento da autonomia intelectual e do pensamento crítico;

IV - a compreensão dos fundamentos científico-tecnológicos dos processos produtivos, relacionando a teoria com a prática (BRASIL, 2013, p. 194).

Especificamente, com relação às etapas do Ensino Fundamental e Ensino Médio, a legislação prevê que as propostas curriculares devam buscar o desenvolvimento do educando e assegurar-lhe a formação para o exercício da cidadania, meios para atuar na sociedade observando princípios éticos e valores democráticos, a compreensão do espaço social, a preparação para o trabalho e a cidadania; o aprimoramento do educando como pessoa humana, a formação de atitudes e valores como instrumentos para uma visão crítica do mundo, e o desenvolvimento da autonomia intelectual e do pensamento crítico. A seguir, transcrevemos os $\operatorname{artigos} 24^{\circ}$ e $26^{\circ}$ das DCNGEB. 
$-24^{\circ}$ (alínea IV), que trata dos princípios e finalidades do Ensino Fundamental:

IV - o desenvolvimento da capacidade de aprendizagem, tendo em vista a aquisição de conhecimentos e habilidades e a formação de atitudes e valores;

$-26^{\circ}$ (alíneas II e III), que tratam das finalidades do Ensino Médio: II - a preparação básica para a cidadania e o trabalho, tomado este como princípio educativo, para continuar aprendendo, de modo a ser capaz de enfrentar novas condições de ocupação e aperfeiçoamento posteriores;

III - o desenvolvimento do educando como pessoa humana, incluindo a formação ética e estética, o desenvolvimento da autonomia intelectual e do pensamento crítico; (BRASIL, 2013, pp. 70,71)

Observadas as diretrizes comuns e as especificidades de cada etapa, o ciclo de desenvolvimento e aprendizagem possui peculiaridades associadas à faixa etária e ao tipo de atendimento. A Educação Infantil tem por objetivo o pleno desenvolvimento da criança em seus aspectos físico, afetivo, psicológico, intelectual e social complementando a ação da família e da sociedade. No Ensino Fundamental, o processo educativo deve propiciar ao sujeito o desenvolvimento da tomada de consciência de seus deveres e direitos frente à sociedade, incluindo a formação ética, o desenvolvimento da autonomia intelectual e do pensamento crítico. No Ensino Médio, como término do processo educativo, além da consolidação dos objetivos pretendidos nas etapas anteriores, a meta é articular trabalho, ciência, tecnologia e cultura na perspectiva da emancipação humana, incluindo, também, uma formação ética e o desenvolvimento da autonomia intelectual e do pensamento crítico. Em geral, ao final da Educação Básica, destaca-se a importância da formação para a cidadania quanto ao cumprimento do prescrito na Constituição Federal. Vê-se, assim, nos destaques em negrito anteriores, ser o desenvolvimento da capacidade de análise crítica ou de senso crítico do educando um elemento comum àquelas etapas da Educação Básica.

De um ponto de vista democrático, um sistema educativo deve atender às necessidades sociais (como os princípios anteriormente citados) e às necessidades pessoais do educando, no que se refere à sua formação (ZABALA, 2002, p. 50). Além da observação de tais princípios, a partir das DCNGEB (artigos $5^{\circ}$ e $6^{\circ}$ ) e de Luckesi (BRASIL, 2013, p 64; LUCKESI, 2011, p. 28), entendemos que a educação, como um direito individual e coletivo, implica habilitar o indivíduo para o exercício de outros direitos e deveres (civis e políticos), potencializando-o como cidadão pleno, capaz de atuar na sociedade como um todo. Portanto, paralelamente ao respeito às individualidades e peculiaridades pertinentes aos diversos grupos existentes, há a necessidade de educar os indivíduos, tornando-os conscientes de seus direitos e deveres para uma vida em sociedade. Tudo isso, a nosso ver, constitui a característica essencial para a composição de um sistema educativo que deve observar seu papel democrático direcionado a uma maioria de cidadãos e cidadãs, além de estar em consonância com correntes gerais de 
pensamento quanto aos aspectos político, social, econômico, filosófico, etc. (ZABALA, 2002, p. 35).

É importante que a Educação favoreça o sujeito a tomar posse de si mesmo (que desenvolva autonomia), administrando as facilidades e dificuldades da vida e do mundo para o seu bem-estar, o bem-estar do outro e do meio ambiente, compreendendo a si e ao mundo de forma cada vez mais ampliada e crítica, conduzindo, por sua vez, a um agir também consciente. Nesse sentido, na Educação Básica, além da prática de transmissão tecnicista de definições ou procedimentos, torna-se necessário que sejam levados em consideração conhecimentos integrados à experiência da vida como um todo, assim como trabalhar a partir das experiências, concepções e valores culturais do ambiente social de cada escola em particular. O currículo é um instrumento mediador desse processo que, a partir da explicitação da compreensão de formação para a cidadania pretendida, aponta o percurso mais indicado, em cada situação escolar específica, para o desenvolvimento de noções, entendimentos, compreensões da realidade e de atitudes, valores, habilidades e saberes (LUCKESI, 1999, p. 27; ZABALA, 2002, p. 18).

Nesses termos, em consonância com a democratização da escola que, ampliou seu atendimento a setores da sociedade deserdados de bens culturais, nessa dissertação, buscamos desenvolver uma prática de ensino voltada a todos os estudantes, observando suas diferenças culturais, sociais, de credos, posições políticas etc.. Nosso objetivo é levar o educando a potencializar capacidades que lhe permitam atuar e responder aos problemas reais em todos os aspectos do desenvolvimento pessoal (social, emocional ou profissional), na perspectiva da formação de um indivíduo autônomo e capaz de intervir na sociedade respeitando, democraticamente, liberdades, direitos e pluralismo de ideias. E assim buscar garantir o disposto no artigo $22^{\circ}$ da LDBEN (BRASIL, 1996): "desenvolver o educando, assegurar-lhe a formação comum indispensável para o exercício da cidadania e fornecer-lhe meios para progredir no trabalho e em estudos posteriores, inspirada nos princípios de liberdade e nos ideais de solidariedade humana".

Antes de finalizarmos o capítulo, cabe mencionar outro aspecto relevante e pertinente às discussões que faremos a seguir sobre os aspectos globais que compõem as finalidades da Educação Básica previstas na Constituição Federal. Referimo-nos às funções e responsabilidades da escola quanto ao ensino e aprendizagem de conhecimentos específicos considerados fundamentais. Nessa discussão estão incluídos necessariamente conteúdos essenciais a serem aprendidos e metodologias de ensino. No último século, discussões e propostas sobre quais são os conteúdos matemáticos fundamentais e os tipos de abordagem 
para os mesmos fizeram surgir correntes de pensamento sobre o ensino de Matemática, como o Movimento Matemática Moderna, o Pragmatismo e o Essencialismo. Em linhas gerais, defendiam metodologias específicas de ensino, muitas delas sem uma preocupação explícita com a formação integral do educando (SKOVSMOSE, 2013, pp. 20-25).

Assim, definir a função da escola e, em consequência, os conteúdos que deve abordar, faz com que seja interessante aprofundar o debate permanente em direção de alternativas curriculares coerentes com os objetivos pretendidos. Portanto, pensando em uma formação mais ampla, como prescrito na legislação brasileira, vale apresentar algumas das contribuições de John Dewey, filósofo e pedagogo americano (1859 - 1952). No Brasil ele inspirou, por exemplo, Anysio Teixeira, líder do movimento denominado Escola Nova (PEREIRA et al, 2009). Dewey e os adeptos dessa corrente destacavam que a adoção do método investigativo em sala de aula conduzia o aluno a uma aprendizagem significativa por desenvolver o pensamento crítico do estudante, tornando-o um indivíduo intelectualmente autônomo e apto a atuar numa democracia. A hipótese desse movimento era que a exposição do educando ao método investigativo, próprio das ciências empíricas, faria com que o estudante desenvolvesse as capacidades de levantar hipóteses, comparar, analisar, interpretar e avaliar - atitudes e comportamentos próprios dos cientistas. Além disso, através das experiências compartilhadas e discussões conjuntas no ambiente escolar, a aprendizagem e a produção do conhecimento seriam coletivas. Nesse processo, em que as discussões são feitas no grupo social da sala de aula, haveria um confronto de ideias e opiniões, e o exercício da democracia seria valorizado, pois a decisão sobre a melhor resposta sobre o problema ocorreria em conjunto.

Dewey, em suas concepções, já mostrava que um ensino, baseado na problematização e investigação, exige do professor o estabelecimento de um diálogo em sala de aula. Problematizar significa propor situações que geram dúvidas e inquietações nos alunos, requerendo a intervenção do professor no sentido de encaminhar possibilidades diversas de escolhas e soluções. Essa concepção de ensino exige do professor uma atuação mais atenta e propositiva, dadas as situações potencialmente imprevistas ou desconhecidas a que estará exposto. Sobre esses aspectos que tratam da relação professor-aluno em sala de aula, discutimos mais amplamente nos capítulos VI E VII.

Segundo Dewey, três funções são atribuídas à instituição chamada "escola", que, em nossa opinião, podem ser associadas localmente aos objetivos de cada componente curricular, em particular, da Matemática. Se tais objetivos forem observados nas abordagens de conteúdos específicos, em nosso entendimento cria-se um ambiente propício à Formação Integral do estudante. Conforme Dewey (Dewey, 1959, pp. 21,22), são elas: 
$\left.1^{a}\right)$ proporcionar um ambiente simplificado de aprendizado em que o educando assimile o conhecimento gradativamente, conforme sua evolução e maturidade, conduzindo-o ao sentido e compreensão dos mais variados aspectos de uma vida social presente na ciência, política, religião, artes, etc. Não é função da escola dar conta ou transmitir todo conhecimento acumulado numa civilização complexa como a atual;

$2^{a}$ ) desvincular o ensino de preconceitos e ideologias, criando um ambiente isento e plural, propício para a ação. É dever da escola, no seu âmbito, permanecer neutra quanto às disputas ou posições religiosas e ideologias políticas, e discutir as realizações que importam para o desenvolvimento harmônico e justo da sociedade. Nesse ponto, em qualquer situação de debate sobre qualquer assunto polêmico, faz-se justo mostrar os diversos pontos de vista (argumentos contra e a favor) existentes sobre o assunto em discussão;

$3^{a}$ ) acolher e fornecer elementos que possibilitem ao indivíduo integrar-se a um ambiente social que extrapole as limitações do grupo social em que nasceu, observando a complexidade e os elementos culturais que compõe o grupo social imediato do educando.

À escola, portanto, cabe facilitar todos os tipos de meios que possibilitem a transição de um pensamento simples para outro complexo (GARCÍA E MERCHÁN, 1977, apud ZABALA, 2002, p. 66). Ou seja, um pensamento que permita ao educando um controle e organização do próprio conhecimento, de sua produção e aplicação à resolução de problemas complexos e abertos, considerando o nível de incerteza presente na vida, na qual é impossível obter sempre uma única resposta válida e verdadeira para os múltiplos problemas que surgem em uma realidade, para interpretar a realidade e intervir na mesma.

A partir das finalidades educativas expressas anteriormente, chega-se à conclusão da necessidade de formar pessoas com conhecimentos, habilidades e valores cuja finalidade primordial consiste em saber resolver os problemas que a vida na sociedade irá colocar-lhes. Diante dessas necessidades formativas, formar um cidadão que compreenda, que analise, que interprete etc., é uma forma de facilitar uma visão mais complexa e crítica do mundo.

O foco da prática educativa, portanto, além da simples transmissão de conteúdos, é a Formação Integral dos Indivíduos, tornando-os conscientes de seus direitos e deveres para uma vida em sociedade, atendendo às diferentes dimensões do desenvolvimento humano: social, interpessoal, pessoal e profissional (ZABALA, 2002, p. 45). 
Observando tais dimensões e a impossibilidade clara de abarcá-las todas em um único trabalho, nosso propósito nesta dissertação é discutir formas de atuação em sala de aula de Matemática que favoreçam a promoção da Formação Integral dos Educandos. Buscamos enfocar aspectos relevantes e compatíveis com uma atuação em âmbito escolar. Inspiramo-nos também na leitura de Paulo Freire, em seu livro Pedagogia da Autonomia (FREIRE, 1996, p. 14), da qual concluímos que o desenvolvimento da capacidade crítica do indivíduo concorre para a promoção dos três aspectos que compõem macro finalidades da Educação Básica, aqui englobados sob a designação de Formação Integral do Estudante: pleno desenvolvimento, formação para a cidadania e qualificação para o trabalho.

Em resumo, são objetos desta dissertação os três aspectos da Formação Integral do Educando, a partir do embasamento teórico adotado: Pleno Desenvolvimento, Cidadania e Qualificação para o Trabalho. Mas é importante frisar que focamos atenção sobre a contribuição que o desenvolvimento de senso crítico pode dar a esta formação, a partir do embasamento teórico aqui adotado com ênfase às duas primeiras finalidades, uma vez que a terceira não é enfatizada nos documentos normativos do Ensino Fundamental (BRASIL, 2013, pp. 39 - 40). 


\section{Capítulo II - Pleno Desenvolvimento, Cidadania e Senso Crítico}

Em seu livro Pedagogia da Autonomia, Paulo Freire afirma que ensinar não consiste apenas em praticar o discurso bancário (transmissão de conteúdos somente), mas ensinar a pensar certo, o que demanda profundidade e não superficialidade na compreensão e na interpretação dos fatos (FREIRE, 1996, pp. 14, 19). O mesmo autor cita que um processo educativo como, por exemplo, o da alfabetização, é condição necessária para a progressão do indivíduo de um estado de ingenuidade à criticidade. A passagem do educando pelo processo favorece a transposição da consciência ingênua para a consciência crítica, permitindo ao indivíduo submeter os fatos a uma análise metódica e mais rigorosa, proporcionando uma compreensão e interpretação mais completa de sua realidade imediata (FREIRE, 1996, p. 23).

No que se refere à Educação Básica, o pensar certo é o pensar mediado pelos conteúdos que são os objetos que conectam ou apoiam os conhecimentos anteriormente adquiridos pelos sujeitos com o objetivo de gerar outro conhecimento, possibilitando a transposição do senso comum, ou pensamento ingênuo (não rigoroso), ao desenvolvimento da capacidade crítica. Assim, neste contexto, são as atividades e situações propostas pelo professor que tornam os educandos capazes de, por exemplo, avaliar os prós e contras ou os potenciais positivos e negativos das aplicações tecnológicas e científicas; rejeitar as várias formas de discriminação e preconceitos de raça e de gênero; e respeitar as identidades culturais. Enfim, é o pensar certo, a ser desenvolvido, que torna o educando capaz de comparar, de valorar, de intervir, de escolher, de decidir, etc. (FREIRE, 1996, p. 14).

Do exposto, baseados em Paulo Freire, podemos concluir que o desenvolvimento da capacidade crítica do indivíduo concorre para a promoção dos três aspectos que compõem a Formação Integral dos Estudantes da Educação Básica que relacionamos neste trabalho, pois esses três aspectos pressupõem uma forma de intervenção na realidade social próxima do indivíduo nos termos de Paulo Freire, comparando, valorando, escolhendo, decidindo, etc. Assim, como contribuição à reflexão sobre o papel que a escola pode assumir objetivando a formação integral do educando, nesta dissertação, inicialmente buscamos investigar as reflexões de autores com relação às discussões que fazem sobre os seguintes aspectos: pleno desenvolvimento, cidadania, qualificação para o trabalho e pensamento crítico.

O pleno desenvolvimento, além do que consta nas Diretrizes Curriculares Nacionais (BRASIL, 2013, p. 169), deve considerar as dimensões intelectual, afetiva, fisica, ética, 
estética, politica, social e profissional. Zabala (2002, pp. 53-56) classifica tais ideias dizendo que o pleno desenvolvimento deve considerar as dimensões social, interpessoal, pessoal e profissional.

A condição essencial para o exercício da cidadania, segundo Paulo Freire, é [o indivíduo] tomar consciência de si mesmo e de sua realidade imediata. Na concepção de cidadania do mesmo autor, desenvolver as potencialidades do indivíduo como ser social e histórico, ser pensante, comunicante, transformador e criador, permite ao indivíduo atuar e construir sua realidade, em oposição àquele que apenas assiste o que acontece à sua volta.

O trabalho (lato sensu), segundo a legislação educacional brasileira, é conceituado na sua perspectiva ontológica de transformação da natureza, como realização inerente ao ser humano e como mediação no processo de produção da sua existência (BRASIL, 2013, p. 215). Não se restringindo, portanto, à preparação profissional ou para o trabalho stricto sensu. Deve assim, ser um processo que capacite o indivíduo à intervenção ética e autônoma na sociedade, cabendo à escola proporcionar atividades que propiciem aos alunos a vivência de ações de interesses coletivo ou pessoal, elaborando, por exemplo, propostas de melhorias no bairro, em sua casa, etc.

O pensamento ou senso crítico parte de observações e, por meio de uma atitude de análise objetiva e racional diante de um determinado aspecto da realidade, manifesta-se em comparações, inferências e julgamentos próprios de uma exposição argumentativa (SILVA, 2000, p. 24). De outra forma, Carraher considera que um indivíduo é dotado de senso crítico quando "[...] possui a capacidade de analisar $e$ discutir problemas inteligente $e$ racionalmente, sem aceitar, de forma automática, suas próprias opiniões ou opiniões alheias” (CARRAHER, 2011, p. XIX; SUMNER, 1940, pp. 632-633). Em oposição, uma postura acrítica consiste em uma conformidade silenciosa.

Define-se o pensar crítico tanto como a capacidade de construir afirmações em conformidade com critérios adotados, como também a de avaliar objetivamente afirmações a partir dos mesmos critérios (LIPMAM, 1995, p. 173; CARRAHER, 2011, p. 14). Assim, no contexto de uma sala de aula de Matemática, para propiciar o desenvolvimento de pensamento crítico, em um primeiro momento é importante propiciar aos alunos espaços que os instiguem a construir e avaliar afirmações, ou seja, propor um trabalho com argumentações que inclua a necessidade da análise de suas veracidades. A partir de agora, apesar de muitos autores utilizarem as expressões "pensamento crítico" e "senso crítico" em 
seus textos, ora como sinônimas ora não, escolhemos utilizar a expressão "pensamento crítico" para nos referirmos a essas modalidades de pensamento.

A seguir, faremos um aprofundamento teórico dessas ideias com o duplo objetivo de relacioná-las com a competência argumentativa a ser desenvolvida pelo educando e com a finalidade de aliá-las a práticas concretas de sequências didáticas, em sala de aula de Matemática.

\section{II.1 Pleno Desenvolvimento}

O ser humano, por motivos genéticos e evolutivos, possui a capacidade não só de adaptar-se ao meio, como também de modificá-lo (pelo trabalho). Transcendendo as características puramente físicas de sobrevivência, seu desenvolvimento decorre também das experiências e aprendizagens que adquire ao longo de sua vida. Segundo Silva (SILVA, 2000, p. 46), esse fato é que confere à educação, em seu sentido mais amplo, uma grande importância na promoção do desenvolvimento humano.

Lembremos que, para Zabala, sem prejuízos de outras dimensões propostas por outros autores, as diferentes dimensões de desenvolvimento da pessoa são a social, interpessoal, pessoal e profissional. Para o autor, a proposta de um ensino que objetiva fortalecer a democracia e formar um cidadão capaz de responder aos problemas que lhes colocará uma vida comprometida com a melhoria da sociedade e deles mesmos, deve levar tais dimensões em consideração. O desenvolvimento social diz respeito ao processo que incentiva o indivíduo a participar ativamente da sociedade em que vive. Assim, um trabalho escolar deve levá-lo a compreendê-la, avaliá-la e intervir nela, de maneira crítica e responsável, com o objetivo de que se torne cada vez mais justa, solidária e democrática. $\mathrm{O}$ desenvolvimento Interpessoal consiste em promover o bom relacionamento com as demais pessoas por meio da cooperação e participação em todas as atividades humanas, com compreensão e solidariedade. O desenvolvimento pessoal é aquele que propicia ao indivíduo compreender a si mesmo, às demais pessoas, à sociedade e ao mundo em que se vive, capacitando o individuo para exercer responsável e criticamente a autonomia, a cooperação, a criatividade e a liberdade. O desenvolvimento profissional (trabalho estrito sensu) é aquele que propicia ao educando dispor dos "conhecimentos e das habilidades que permitam às pessoas exercer uma tarefa profissional adequada às suas necessidades e capacidades" (ZABALA, 2002, pp. 54-56). 
Nesta dissertação, sem prejuízo de outras concepções, entendemos que o pleno desenvolvimento humano engloba o desenvolvimento pessoal, a interação social, a apropriação de linguagens pertinentes aos conhecimentos científicos tecnológicos e culturais, a discussão de conhecimentos considerados social e culturalmente relevantes, o desenvolvimento do pensamento crítico e o desenvolvimento do raciocínio lógico. Devido à complexidade científica e tecnológica da sociedade atual, é relevante o papel da escola como mediadora entre os estudantes e as produções científicas, tecnológicas e culturais, próprias da sociedade onde se insere. Tal mediação se dá por meio do oferecimento de um conjunto de atividades que favoreçam a construção de pensamento abrangente, pois para a tomada de decisão frente a um problema, aspectos lógicos e éticos devem ser considerados e, nesse sentido, faz-se necessária a mobilização de conhecimentos de diversas áreas. A busca pelo pleno desenvolvimento dos educandos, portanto, deve favorecer uma educação que promova um maior conhecimento do mundo e a autonomia para atuar conscientemente em benefício de todos.

A escola, desse modo, tem a responsabilidade de despertar a consciência crítica oferecendo experiências, oportunidades de reflexões e estímulo à criatividade. Como diz Paulo Freire (1996, pp. 11, 12), o ideal da educação não é aprender ao máximo absorvendo conteúdos em quantidade, mas antes de tudo aprender a aprender; é aprender a se desenvolver e aprender a continuar a se desenvolver depois da escola e, para isso, o equilíbrio entre esses três fatores devem se dar não de forma estática, mas progressiva.

Fica claro que a busca pelo pleno desenvolvimento demanda uma articulação conjunta de todas as áreas do conhecimento na escola. Neste trabalho, discutiremos alguns aspectos de como a Matemática pode contribuir nessa direção.

\section{II.2 Cidadania}

A ideia de cidadania transcende à apropriação de direitos formalmente garantidos. Formar para a cidadania consiste em propiciar que o indivíduo se torne competente para atuar em um espaço de divergências e de conflito de ideias, com as influências culturais e com os sentimentos presentes nas relações do sujeito com o mundo e consigo mesmo. A educação para a cidadania, portanto, deve ultrapassar o discurso da mera conquista de igualdade de direitos e chegar à compreensão de que ela significa prover os indivíduos de 
instrumentos para a sua plena realização e participação em uma sociedade respeitando os projetos individuais e coletivos (MACHADO, 1997, p. 106).

O exercício da cidadania, em sua plenitude, somente pode ocorrer em um ambiente democrático.

Paulo Freire, Skovsmose e Dewey propõem uma concepção de educação mais ampla, que vá além da sala de aula e dos muros da escola, fazendo-se útil à vida em sociedade. Essa utilidade, conforme já comentamos, refere-se à formação de cidadãos em sua plenitude, o que pode ser consubstanciado, no contexto escolar, pelo estímulo ao engajamento e participação dos educandos em seu processo de aprendizagem. Para tanto, segundo Freire e Skovsmose, é a comunicação entre alunos e professores em sala de aula que pode transmitir valores como a tolerância e o respeito pela diversidade e atitudes.

Assim, estimular o diálogo em sala de aula por meio de argumentações justificadas é essencial para que se formem cidadãos críticos e para que, simultaneamente, se construa uma micro sociedade democrática naquele espaço escolar (ALRǾ, 2010, pp. 11-14). Por último, para Dewey, em sua interpretação pragmática de Ciência, o ambiente da sala de aula deve estimular o processo de investigação e pesquisa. Segundo Skovsmose (2013, p. 40), o não favorecimento da investigação, mas apenas da prática de exercícios repetitivos com uma única resposta, por exemplo, está relacionado ao trabalho rotineiro que cria relações autoritárias entre professores e alunos e que não promove a pluralidade e respeito pela diversidade de ideias.

Partindo da concepção do processo educacional como um diálogo, a Educação Crítica (SKOVSMOSE, 2010, p. 13) é uma corrente de pensamento que destaca a necessidade da participação ativa dos estudantes no processo educacional, em contraposição a uma Educação Bancária, definida e caracterizada pela transmissão ou transferência de conhecimentos (FREIRE, 1996, p. 11; 2005, p. 33-35). Sobre essa concepção de educação como diálogo, que Skovsmose quer adaptar para uma sala de aula de Matemática, no pressuposto de que a relação entre professor e alunos deve ser de diálogo, onde o professor não apenas ensina, mas também aprende ao ensinar, vale mencionar um trecho do livro "Pedagogia Emancipadora", citado por Skovsmose:

Através do diálogo, o professor-dos-estudantes e os estudantes-do-professor se desfazem e um novo termo emerge; professor-estudante com estudantesprofessores. O professor não é mais meramente aquele-que-ensina, mas alguém a quem também se ensina no diálogo com os estudantes, os quais, por sua vez, 
enquanto estão ensinando, também aprendem. Eles se tornam conjuntamente responsáveis por um processo no qual todos crescem (Paulo Freire, apud Skovsmose, 2013, p 17).

Educação Bancária se contrapõe, ainda, à educação dialógica nas consequências de sua prática, pois esta última modalidade, segundo Fernandes (2011, p. 44) forma cidadãos atentos, inseridos, participantes nas questões históricas e sociais a que pertencem; forma cidadãos enraizados, conscientes, que se apropriam de sua cultura, não de forma individualizada, mas no diálogo com o mundo e com seus semelhantes.

Esse tipo de espaço social, em que o diálogo prevalece, é o que chamamos de democracia e constitui a base para o desenvolvimento da cidadania (FERNANDES, p. 19, 2011). Democracia é uma forma ideal de organização social, compreendendo dimensões política, jurídica, econômica e cultural que, individualmente, estabelecem valores, normas e comportamentos visando o bem maior que é a vida em sociedade. A integração do educando no ambiente social, como sujeito que exerce seus direitos e deveres e desenvolve seus potenciais, dá-se por meio do exercício do diálogo e da cidadania (FREIRE, 1996, p. 61).

Em um ambiente democrático, as pessoas encarregadas de tomar decisões e executálas devem submeter-se ao julgamento sobre a adequação de seus atos por parte dos diretamente atingidos. Ou seja, "a competência para governar é de natureza especial, ao passo que a competência para julgar é de natureza comum - esta última, também é chamada de competência democrática" (SKOVSMOSE, 2013, p. 46). A partir dessa interpretação, em uma sala de aula como um ambiente democrático, alunos e professores participam diretamente das decisões, retirando o foco da escolha dos "governantes" ou daqueles que irão representá-los. Esse tipo de democracia participativa, mesmo sendo impraticável inteiramente em sociedades complexas, pode ser aplicado tanto em locais de trabalho como em escolas e salas de aula. Nestes dois últimos, são claramente viáveis a sua prática.

A atitude crítica capacita o indivíduo a ter discernimento sobre a realidade. A escola pode aguçar a consciência de contradições ou de aspectos desfavoráveis que existem na sociedade, por meio da promoção de uma consciência crítica (FREIRE, 1996, pp. 16) e, com isso, pode favorecer mais plenamente a formação para a cidadania. 


\section{II.3 Qualificação para o Trabalho}

O Trabalho é conceituado em duplo sentido nas Diretrizes Curriculares Nacionais ontológico e histórico. O primeiro, como princípio educativo, indica o potencial humano para transformar sua realidade material e social. O segundo é entendido como prática econômica, qualquer atividade humana de subsistência individual que produza riquezas e satisfaça necessidades (em stricto sensu) (BRASIL, 2013, p. 163). A qualificação para o trabalho em âmbito escolar diz respeito ao desenvolvimento da capacidade do educando para intervir, de forma consciente e intencional, na transformação de seu espaço social próximo. Ou seja, preparar o estudante para ser ator e autor de sua própria vida. Viver em sociedade implica estar em constante interação com outras pessoas. Um processo de intervenção consciente nesse espaço de atuação se dá por meio da construção, utilização e transformação de saberes, conhecimentos e valores. A finalidade da educação nesse processo é o pleno desenvolvimento dos educandos e a formação de cidadãos atuantes, autônomos e conscientes de seus direitos e deveres, comprometidos intencionalmente com a transformação social. A meta é propiciar que o educando se torne apto a viver e conviver nos diversos ambientes onde se dão as relações sociais, sejam elas culturais, científicas, de práticas sociais, etc. (BRASIL, 2013, p. 16).

Um processo harmônico que vise uma intervenção no ambiente social próximo, dessa forma, pressupõe a prática de preceitos como a ética, o respeito aos outros e a si mesmo quanto à observação de direitos e deveres individuais e coletivos, etc.. Tal fato demonstra que a qualificação para o trabalho, prevista na legislação educacional, tem estreitas relações com aspectos que compõem o desenvolvimento social, interpessoal, pessoal e profissional, dos quais tratamos anteriormente, bem como a formação para o exercício da cidadania (BRASIL, 2013, p. 16).

Portanto, vimos que a qualificação para o trabalho é indissociável do pleno desenvolvimento e da formação para cidadania dos estudantes. Já vimos que o senso crítico é indispensável para atuação consciente, autônoma e responsável dos cidadãos na sociedade. Assim, novamente, a promoção de uma consciência ou pensamento crítico (e que tratamos a seguir) facilita ao indivíduo uma atuação visando o convívio social com fins de buscar o desenvolvimento individual e coletivo. 


\section{II.4 Pensamento Crítico}

O senso crítico, conceito desenvolvido na última metade do século XX por Michael Scriven e Richard Paul (SILVA, 2000, p.12; DINUȚĂ, 2014), é uma forma de pensamento. É um processo intelectual de análise, síntese, conceptualização e avaliação da informação que, em qualquer situação de interlocução interpessoal, possibilita aprimorar a qualidade dos julgamentos quanto à: clareza, precisão, consistência, relevância e imparcialidade de conceitos, conclusões, implicações e consequências.

Desenvolver o pensamento crítico é um processo complexo. Ter pensamento crítico pressupõe dominar conhecimento suficiente para formar suas próprias opiniões, além de ser capaz de submeter suas próprias ideias a outros, mostrando tolerância e respeito às ideias e opiniões alheias (RICHARD ET AL, 2008; RICHARD, 2012).

Segundo Minakova (2014), o pensamento crítico pode ser considerado como a habilidade de selecionar um problema, analisar a situação, escolher as ações correspondentes para uma solução racional e avaliar os resultados. O pensar criticamente também se refere ao pensamento que almeja o julgamento bem formado e que utiliza padrões de avaliação em uma tentativa de determinar o valor de verdade ou falsidade de uma afirmação. No meio educacional, o desenvolvimento do pensamento crítico tem recebido importância e aberto espaços para outras abordagens conceituais, conforme as necessidades e peculiaridades de cada disciplina (DEMIRA, 2011). Em Matemática, por exemplo, Haskins (apud DEMIRA, 2011) diz que pensamento crítico é mais do que pensar lógica ou analiticamente, devendo ser entendido como um pensamento objetivo e racional. Para Haskins, Lógica e Análise são conceitos matemáticos, enquanto um pensamento racional e objetivo pode ser utilizado em várias outras áreas do conhecimento. Dessa forma seguimos a posição tomada por autores como Carraher (2011) e Scriven, entre outros, para observar tanto as nuances conceituais do tema, como para perseguir nosso objetivo maior, que é entender como favorecer o desenvolvimento dessa modalidade de pensamento nos estudantes da Educação Básica em sala de aula de Matemática.

Os aspectos comentados, que caracterizam o pensamento crítico (RATHS et al, 1977 apud SILVA, 2000, p. 48), além de fornecerem orientações para elaboração de atividades didáticas, mostram que tal modalidade de pensamento pode ser desenvolvida em todas as disciplinas do currículo escolar para fins de compreensão e aprendizado de novos conhecimentos. Segundo Lipman, se o pensamento crítico pode produzir uma melhoria na 
educação, será porque aumenta a quantidade e a qualidade do significado que os alunos retiram daquilo que leem e percebem, e que expressam através daquilo que escrevem e dizem (LIPMAN, 1995 apud SILVA, 2000, p. 37).

O mundo atual exige dinamismo dos indivíduos, que tomem decisões e solucionem problemas cada vez mais complexos. Isso requer do cidadão imerso na Era da Informação não somente que aprenda a construir seu conhecimento, como também que desenvolva habilidades de pensamentos superiores, como o pensamento crítico (SEZER, 2008, apud UDI, 2011). Posto isso, percebemos a necessidade do indivíduo aprimorar sua qualidade de pensamento e destacamos o desenvolvimento do denominado pensamento crítico, pois seu domínio permite entender e lidar com vários aspectos da realidade próxima de maneira independente e objetiva, habilidade necessária em todas as áreas do conhecimento e profissões (UDI, 2011). O desenvolvimento do pensamento crítico, a ser promovido nas diversas etapas do ensino elementar, tem um importante papel na produção de conhecimentos em todas as áreas do conhecimento em que haja a necessidade de uma reflexão sobre justificativas que sustentem uma tomada de posição (SILVA, 2000, p. 56).

Seja como uma das exigências de um país que caminha para a democratização ou para fins de alterações no quadro político-econômico, é a educação, e nela a valorização daquela modalidade de pensamento, que permite ao sujeito compreender a realidade e escolher a forma de atuar em sociedade, optando por alternativas ou soluções que visem ao bem-estar de todos (FREIRE, 1996, pp. 20, 71). Uma atitude crítica é elemento essencial para o desenvolvimento da capacidade de discernimento sobre a realidade, influenciando diretamente na possibilidade de intervenções conscientes voltadas a transformações sociais. Em outras palavras, conforme Paulo Freire (1999, pp. 95, 105), a aquisição da consciência crítica assegura a atuação do indivíduo como sujeito em sua realidade, e a Educação é o instrumento para despertar a capacidade crítica.

O exercício dessa modalidade de pensamento, portanto, demanda habilidades já desenvolvidas (e não apenas potenciais) presumivelmente por meio de leitura, reflexão e da própria prática constante de pensar sobre o mundo e observar as relações existentes nos temas investigados. O pensador crítico, ou o indivíduo que possui senso crítico, questiona e analisa situações pelo simples desejo autônomo de compreender e descobrir; faz a leitura crítica de revistas e jornais produzidos para consumo em massa, bem como a avaliação crítica de filmes, de programas de televisão ou de palestras. É capaz de analisar distorções ou tendenciosidades dos discursos veiculados pelos diversos meios de comunicação. Assim, o pensamento crítico está estreitamente associado à capacidade do indivíduo de tecer 
julgamentos, diferenciando, em uma dada situação, entre o que é melhor e o que é pior, entre o que é lógico e o que é ilógico ou o que é verdadeiro e o que é falso, no contexto.

No entanto, dada a presença de tradições e culturas próprias de cada contexto, para promover o desenvolvimento dessa modalidade de pensamento, faz-se necessário criar condições ou ambientes que estimulem o educando a questionar, comparar e justificar suas convicções de forma coerente. Também é importante que os julgamentos realizados sejam confiáveis, nas diversas situações de interações sociais dos indivíduos (científicas, religiosas, culturais, de simples práticas sociais, etc.). Para tanto é necessário elaborar opiniões e pensamentos a partir de uma base firme e de critérios que orientem os julgamentos, como padrões éticos ou morais, leis, costumes e tradições, preceitos, condições e parâmetros, convenções, normas e generalizações, princípios, suposições e definições, ideias, propósitos e intuições, testes, provas concretas, descobertas experimentais, métodos, medidas, entre outros.

Nas ciências experimentais e na Matemática, o exercício do pensamento crítico é uma prática comum, pois julgar, analisar, avaliar e estabelecer relações entre as afirmações são aspectos importantes a serem considerados no que se refere à construção de seus conhecimentos. Mesmo com as peculiaridades próprias, como linguagem subjacente e métodos de validação, em todas elas os argumentos são passíveis de avaliação e validação segundo padrões lógicos ou experimentais, ou seja, segundo critérios previamente estabelecidos que, simultaneamente, concorrem para a promoção de novos conhecimentos.

Em Educação Matemática, por exemplo, Maričić (2011 apud MARIČIć, 2014), em dois artigos, define o pensamento crítico como uma atividade intelectual complexa que enfatiza as seguintes habilidades: formulação de problemas, reformulação de problemas, avaliação e percepção do problema. A formulação de problemas inclui as habilidades de perceber o problema e formulá-lo matematicamente conforme a situação proposta, utilização adequada de simbolismo matemático nessa representação, etc.. A reformulação de problemas inclui, por exemplo, elaborar conclusões baseadas na identificação das conexões e relações no conteúdo de uma tarefa por meio da exposição de argumentos claros. A avaliação está relacionada à aferição de informações, soluções e opiniões de autoridades. A percepção ou sensibilidade aos problemas incluem a detecção de informações implícitas na formulação do problema, a habilidade de identificar inconsistências e contradições, identificar informações redundantes. Portanto, em sala de aula de Matemática, as atividades 
elaboradas devem promover o desenvolvimento dessas habilidades e contribuir para a formação do pensador crítico.

A partir do exposto, podemos dizer que caracterizar o pensador crítico da forma mais abrangente possível é uma tarefa das mais complicadas, pois o desenvolvimento dessa habilidade está, muitas vezes, atrelado ao seu contexto de uso (MARIČIĆ, 2014). Em Educação Matemática, a preocupação em definir critérios para decidir se essa modalidade de pensamento está realmente sendo desenvolvida nas aulas de Matemática é intrínseca às investigações sobre como desenvolver e conceituar o pensamento crítico. Nesse caso, os critérios de avaliação sobre a efetividade de tal objetivo podem variar segundo os tipos de conteúdo abordados, se, por exemplo, Álgebra, Geometria ou Estatística.

O conhecimento matemático é necessário ao desenvolvimento de nossa sociedade tecnológica e, como aplicação de suas ferramentas, também faz parte do processo de construção de conhecimentos de outras áreas, por meio da modelagem matemática de situações ou eventos. Dessa forma, como contribuição da escola quanto às possíveis mudanças em um quadro social, o desenvolvimento do senso crítico dos educandos é de fundamental importância, sendo, portanto, coerente a presença desse objetivo no currículo escolar. Assim, nossa hipótese é que, no que tange à Matemática e ao seu ensino, com uma metodologia adequada também se pode perseguir o objetivo de desenvolver essa modalidade de pensamento. Concomitantemente, como isso se dará a partir do trabalho de conteúdos específicos, estaremos produzindo novos conhecimentos pertinentes a esta ciência e a outros contextos além dela, contribuindo ainda mais para a Formação Integral dos Estudantes.

Pensar criticamente não é censurar ou encontrar defeitos e não pode ser desenvolvido por meio do estímulo de discursos acirrados em sala de aula nos quais os alunos, no máximo, emitem suas opiniões baseadas em convicções pessoais, eventualmente emocionais ou sectárias. O objetivo do desenvolvimento de senso crítico em sala de aula é ampliar o conhecimento e o discernimento sobre ser ou não uma argumentação bem justificada. E o papel do professor num espaço de debates é orientar os alunos quanto à necessidade da adoção de afirmações que podem ser analisadas, questionadas ou avaliadas, e que tenham potencial de agregar conhecimentos novos a partir do contexto em questão. Esses pontos abordados, juntamente com as diversas definições de pensamento crítico, mostram que as especificidades de cada disciplina necessitam ser observadas quando se quer desenvolver a consciência crítica. Em se tratando de Matemática, sem um trabalho com conteúdos, nenhuma estratégia, método, forma ou composição de ensino pode ter uma influência significativa sobre o desenvolvimento dessa modalidade de pensamento. Nesse sentido, no 
ensino de Matemática é necessário observar suas especificidades, tanto do ponto de vista da linguagem simbólica pertinente, quanto ao seu método de produção específico. Buscamos, então, definir critérios que orientem a verificação pelo professor de uma avaliação dos resultados de uma aplicação de atividades com tal objetivo, no sentido de abarcar todos os contextos matemáticos possíveis. Destacamos as propostas de Carraher (2011) e de Skovsmose quanto a isso. O primeiro estabelece critérios para caracterizar o pensador crítico e o segundo, em sua proposta denominada Educação Matemática Crítica, discute o papel que cabe à Matemática escolar no desenvolvimento do pensamento crítico.

Segundo Carraher, um pensador crítico tende a demonstrar as seguintes características gerais:

1. Uma atitude de constante curiosidade intelectual e questionamento;

2. A habilidade de pensar logicamente;

3. A habilidade de perceber a estrutura de argumentos em linguagem natural;

4. A perspicácia, isto é, a tendência a perceber além do que é dito explicitamente, descobrindo as ideias subentendidas e subjacentes;

5. A consciência pragmática, um reconhecimento e apreciação dos usos práticos da linguagem como meio de realizar objetivos e influir sobre os outros;

6. Uma distinção entre questões de fato, de valor e questões conceituais;

7. A habilidade de penetrar até o cerne de um debate, avaliando a coerência de posições e levantando questões que possam esclarecer a problemática.

(CARRAHER, 2011, p. XX)

Em linhas gerais, a atitude de curiosidade intelectual não se satisfaz com respostas locais do leigo, ou seja, em que prevalece o senso comum, ouvir dizer ou fofocas. Refere-se ao interesse em compreender fenômenos profundamente. A Lógica pode contribuir para que o indivíduo reflita sobre seus saberes e aprimore seu raciocínio, tornando-o claro e coerente na transmissão de suas conclusões às outras pessoas. Reconhecer a estrutura de argumentos em linguagem natural diz respeito às formas corretas de argumentação, ou formas lógicas presentes em argumentos provenientes das mídias em geral ou conversas informais. A habilidade de perceber elementos, além daqueles que são explicitados, requer a apropriação de ferramentas além do raciocínio lógico para efetuá-la, como, por exemplo, conhecimentos prévios do tema são necessários para fazer deduções ou analogias. Os usos práticos da língua referem-se às afirmações que têm a função de persuadir e não convencer. Por exemplo, afirmações corriqueiras na mídia que têm o propósito de transmitir uma informação tendenciosa. Em geral, mesmo não sendo informações falsas, podem gerar mal-entendidos, pois quem está recebendo a mensagem não tem acesso ao contexto. Discutimos melhor essa 
habilidade, no decorrer desta dissertação, ao tratarmos do capítulo sobre Educação Matemática Crítica e no desenvolvimento do segundo experimento. Questões de fato, de valor e conceituais referem-se, por exemplo, a conhecimentos científicos, questões religiosas, e construção de conceitos, e só podem ser discutidas em termos de uma base comum de conhecimentos, ou com o estabelecimento de parâmetros consensuais. Finalmente, a possibilidade de penetrar até o cerne de um debate depende do domínio de raciocínio lógico, da capacidade de fazer relações e inferências, e de um bom conhecimento do tema em questão.

Segundo Skovsmose (2014), a Educação Matemática Crítica visa à formação matemática dos estudantes, não apenas do ponto de vista da assimilação de conteúdos e técnicas, mas também capacitá-los à reflexão sobre o papel dessa ciência na sociedade atual. Fazendo uma analogia com a noção de literacia de Paulo Freire, diz o autor ser importante favorecer um processo de alfabetização matemática como suporte para o educando se reconhecer como ator e autor da própria vida. A função da educação matemática escolar visa fornecer um suporte para o desenvolvimento de cidadãos críticos, de forma que as pessoas se sintam capazes de atuar nos processos político-econômicos da sociedade em que estão inseridos. Em particular, há necessidade de desenvolver o senso crítico, ou competência crítica dos indivíduos, relativamente ao emprego de matemática em contextos sociais.

Essa abordagem educacional para o ensino de Matemática faz referência a uma variedade de perspectivas que dizem respeito a aspectos sociais e políticos do aprendizado em Matemática, ao acesso das ideias matemáticas a todos, independentemente de sexo, cor, classe social, etc., ao uso e função da Matemática (aplicações tecnológicas avançadas ou na vida cotidiana), à vida em sala de aula, que deveria representar um espaço democrático onde as ideias são apresentadas e negociadas e ao desenvolvimento de um cidadão crítico. Segundo Skovsmose (2013, pp. 40-46), a observação pelo aluno de todos os espaços em que a Matemática está presente, junto com a valorização da democracia em sala de aula, pode contribuir para uma maior compreensão dessa área do conhecimento e, ainda, contribuir para desenvolver a criticidade no educando.

Neste trabalho, a busca por propiciar o desenvolvimento do senso crítico dos estudantes foi feita por meio do estabelecimento de um espaço de argumentações, pois entendemos que um ambiente em que o aluno é convidado a expor, avaliar e validar afirmações é onde tal tipo de pensamento pode se manifestar. 
Fazemos, a seguir, uma discussão sobre argumentações e sobre como estas podem ser trabalhadas em sala de aula de Matemática, enfatizando que elas não se restringem a elaborações de provas ou demonstrações matemáticas. 


\section{Capítulo III - Argumentação}

Todo processo de comunicação, como os diálogos, as comunicações artísticas, culturais, musicais, etc., são atividades sociais. Em especial, o diálogo, além de um modo de interação, é um espaço de produção de análises. Apresenta-se sob a forma de discursos, argumentos e questionamentos, proporcionando a exposição e confrontação entre pontos de vistas distintos. Dessa forma, o diálogo é uma forma de se promover o conhecimento, particularmente por meio do uso de argumentações (ALRØ, 2010, pp. 12, 14).

Um argumento, como tipo de diálogo, é caracterizado por suas finalidades e forma específicas. Quanto à sua finalidade, nas diversas situações cotidianas ou nas práticas sociais, culturais e científicas, o objetivo de um argumento é o convencimento de outros. Ele é utilizado para sustentar um ponto de vista particular, justificar ou refutar uma ideia, um conceito ou opinião. Quanto à sua forma, diferentemente de interjeições ou sentenças interrogativas, um argumento é uma proposição composta por premissas e conclusão, em que as primeiras devem fornecer evidências para a última. Exige, na maioria das vezes, a mobilização de recursos e de múltiplas formas de discurso, além do "raciocínio lógico", para sua validação. Assim, a Matemática é uma área propícia para o trabalho escolar com argumentações, uma vez que elas estão no centro de sua prática. Provas, demonstrações, raciocínio indutivo e discussão de exemplos e contraexemplos compõem seus métodos de validação, tendo o propósito de confirmar ou refutar afirmações, verificar ou esclarecer resultados.

Autores como Ducrot e Anscombre (1983) definem a argumentação como a ação verbal pela qual um sujeito - individual ou coletivo - procura levar um auditório a aceitar uma determinada tese, valendo-se para tanto de recursos que visam estabelecer a verdade, a validade ou o bom fundamento da mesma. A argumentação, utilizada para convencer, visa à adesão consciente e permite colocar as ideias em contraste para a construção de novos conhecimentos. Nesse sentido, a explicitação dos motivos que tornam a conclusão uma consequência das premissas é fundamental. Convencer é diferente de persuadir. Etimologicamente, convencer significa (com + vencer), ou vencer junto com o outro, de modo que esse "outro" compartilhe da aceitação dos argumentos pelo expositor. Por outro lado, persuadir está ligado ao campo da emoção e significa induzir ou levar a crer na argumentação, muito mais por efeito de uma relação psicológica entre quem fala e quem ouve do que pela compreensão das ideias. 
A argumentação, ou a linguagem argumentativa, é uma das principais características do processo de construção dos conhecimentos científicos. Cada ciência tem seu modo de produção definidos por suas linguagens específicas e pelas argumentações consideradas válidas pelos especialistas. Na sua construção, empreende-se o esforço de excluir o erro e contradições internas e de bem definir os pressupostos teóricos, buscando sempre maximizar a coerência e exatidão dos resultados obtidos. Assim, por exemplo, as Ciências da Natureza se utilizam do método experimental. Já a validação em Matemática baseia-se no método lógico-dedutivo. Por meio de algum desses processos, um corpo ordenado de conhecimentos é construído gradativamente em cada ciência (DEWEY, 1959, p. 20).

As argumentações nas Ciências da Natureza, por intermédio das linguagens oral e escrita, fazem forte uso da linguagem matemática. Esta última, expressão de pensamento humano, não deve ser entendida como uma tradução direta do fenômeno em estudo e sim como ferramenta para a modelagem de fenômenos físicos, químicos ou biológicos. Nesses contextos, a validade da conjectura depende da verificação empírica dos resultados, que podem sustentar o modelo matemático ou refutá-lo. Portanto, a linguagem matemática contribui, com suas ferramentas e características próprias, para a estruturação do pensamento científico e não para a decisão sobre a validade ou falsidade do resultado.

Para fins de refutação ou de validação de um argumento, um aspecto importante é o conhecimento prévio ou o sistema de referência comum que se tem do assunto em questão. Se observado que um argumento não é válido, o contexto da discussão deve ser considerado para a produção de contraexemplos que o refutem. Em caso de não ser refutado, precisa ser comprovado, também observando o contexto e a linguagem adequada ao contexto (KO, 2013). Em contraste com os métodos das ciências empíricas, a validação de uma afirmação matemática depende somente da correção lógica da argumentação que a comprova. Essa relação necessária entre as premissas e a conclusão do argumento é o que chamamos prova ou demonstração.

No entanto, mesmo as pessoas não possuindo conhecimento de Lógica ou de qualquer instrumento formal de validação, costumam adotar estratégias para a solução de problemas ou explicitar os motivos pelos quais acreditam que as conclusões obtidas seguem das premissas. Formulam assim justificativas não formais que, sendo coerentes, devem ser valorizadas. É, portanto, função específica da matemática escolar favorecer a discussão sistemática desses modos informais de validação para fins do desenvolvimento do senso crítico. 
Mesmo os cientistas, na produção de novos conhecimentos, passam por uma etapa anterior àquela da validação, que consiste na formulação de conjecturas a serem investigadas, e mediante a qual, a partir da observação de padrões, buscam formular novas hipóteses plausíveis. Nessa fase, utilizam da intuição, de conhecimentos prévios, de testes e de exemplos particulares e justificativas informais para o estabelecimento de uma nova conjectura. A validação formal é, assim, uma etapa posterior no trabalho do cientista, que visa o registro e a comunicação do resultado obtido aos seus pares. Nesse sentido, é inadequado praticar um ensino que privilegie a mera assimilação de símbolos sem significação para os educandos e a transmissão de um lastro de conhecimentos informativos, sem indicações de caminhos para a descoberta de relações entre os mesmos com objetos do cotidiano, da vida em sociedade ou de outras áreas do conhecimento (DEWEY, 1959, p. 37). Concluímos, então, que a primeira etapa do processo de criação do conhecimento matemático, deve ser valorizada no contexto escolar com vistas à formação básica dos educandos.

Em sala de aula, os significados das linguagens simbólicas só podem ser apreendidos, com atribuição de significados, se ficarem claros para os estudantes como são empregados para obter novos conhecimentos. Nas palavras de Dewey (1959, p.77), "não se conhece uma máquina enumerando-se todas as peças que entram em sua estrutura e sim sabendo-se as utilidades das mesmas, e podendo-se dizer porque são usadas. Conhecer definições, regras, fórmulas, etc., é o mesmo que conhecer as partes de uma máquina sem saber qual seu emprego e, por exemplo em Matemática, terá conhecimento das concepções matemáticas somente quem compreender os problemas em que elas entram e sua utilidade especial para resolver estes problemas". As propriedades dos objetos são valorizadas tanto como necessidade de comunicação quanto para desenvolvimento da atividade matemática. Assim, a fim de praticar um ensino que visa à obtenção de conhecimentos matemáticos, há a necessidade de discutir-se o papel da terminologia científica ou da linguagem simbólica com os alunos, privilegiando o aprendizado do significado da linguagem pertinente às ciências (DEWEY, 1959, pp. 244, 245). No contexto escolar, portanto, a construção de argumentos permite, conforme diz Paulo Freire (1999, p. 93), "a prática de uma educação que leve o homem a uma nova postura diante dos problemas de seu tempo e de seu espaço e a opção pela prática escolar de construção de conhecimentos, ao invés da memorização e repetição mecânica”. A prática de argumentar, tornada hábito no contexto de uma sala de aula, significará a transposição do autoritarismo e de rotinas próprias de um ambiente não democrático, "diferenciando a educação libertadora (que estimula o diálogo e promove a 
democracia) da educação bancária (que não estimula o pensar, nem o agir)" (FREIRE, 1999, p. 100).

Dito isto, no que se refere à Formação Integral do Educando e sobre como o ensino de Matemática pode contribuir para tal, é essencial conhecer o corpo de conhecimentos acumulados em Matemática, suas ideias fundamentais, aplicações e métodos de validação, etc., potencializando os indivíduos a construírem e avaliarem afirmações que façam uso dos conhecimentos matemáticos. Dessa forma, estaremos favorecendo que o educando desenvolva meios para explorar as diversas maneiras de se utilizar argumentos matemáticos, contribuindo para a promoção do conhecimento e para formação de cidadãos críticos.

\section{III.1 Argumentações Matemáticas}

Fornecer explicações, aplicar resultados, extrair conclusões ou fornecer argumentos utilizando linguagem matemática (representações simbólicas, relações e operações, além de linguagem pertinente) para conectar ideias matemáticas, são formas de comunicação e de expressão de pensamentos matemáticos (D'AMORE, 2007, p. 246). Assim, a partir dessa afirmação, para fins de construção desta dissertação, chamamos de argumentação matemática a comunicação na qual se relacionam adequada e coerentemente premissas envolvendo ideias, conceitos ou resultados matemáticos com a conclusão enunciada (novo conhecimento).

Destacamos aqui duas categorias de argumentos matemáticos, utilizados em contextos distintos de produção de conhecimentos, científicos ou não: argumentações em Matemática e argumentações com Matemática. A primeira tem como objetivo a construção e validação de conhecimentos matemáticos, tanto pelo matemático profissional como pelo aprendiz dessa ciência. A segunda comporta a utilização de noções matemáticas em situações cotidianas ou no trabalho, como o uso de ferramental matemático na formulação de modelos apropriados a áreas sociais, científicas ou tecnológicas.

Mesmo considerando a produção e validação de conhecimentos em outras áreas que se beneficiam de resultados da Matemática para estabelecerem seus conhecimentos próprios, a comunicação sobre as suas veracidades, com justificativas, dá-se de formas específicas que dependem do contexto das afirmações. A Matemática, do ponto de vista acadêmico, faz uso do método axiomático para a construção de teorias e do raciocínio lógico-dedutivo para validar resultados. Por outro lado, áreas que utilizam o ferramental matemático para validar decisões, podem utilizar modos diferentes de validação, como o raciocínio estatístico ou o 
indutivo. Portanto, as validações de afirmações em contextos puramente matemáticos diferem substancialmente das validações externas a ela (mesmo fazendo uso dela), uma vez que outros elementos pertinentes ao contexto, além do ferramental matemático (linguagem simbólica, teorias estatísticas, combinatórias, probabilísticas, algébricas, etc.), precisam ser considerados.

Em geral, podemos dizer que em Matemática pura, demonstrações são tipos de argumentações que buscam a relação necessária entre as premissas e a conclusão. Baseiamse no uso de terminologia formal específica e regras precisas para seu emprego na escrita matemática, juntamente com a utilização do método axiomático como método de validação. As regras de dedução têm a função de interconectar proposições matemáticas, importando apenas a estrutura lógica e as relações entre os objetos para fornecer uma compreensão formal da interdependência entre os fatos matemáticos envolvidos. É essa metodologia de validação de resultados que confere o caráter de rigor e precisão característico dessa ciência e a torna útil em vários contextos do cotidiano, do mundo do trabalho ou em outras práticas sociais. Mais adiante, discorremos sobre as validações matemáticas pertinentes ao contexto de sala de aula e à prática do matemático profissional.

Por outro lado, observados os ambientes em que os conhecimentos e linguagem matemáticos estão inseridos, ou possuem papel estruturante - como em Economia, Política, Administração, Ciências etc. - decisões que são socialmente relevantes também podem ser influenciadas por modelos matemáticos e suas aplicações. Os seguintes são exemplos de tais situações: decidir sobre a ajuda financeira a um município ou país, dado seu grau de pobreza, definir a meta de um empregado numa linha de produção; definir níveis aceitáveis de poluição (ar, sonora, etc.), ou no caso particular do uso da Matemática na política, em que representantes eleitos convencem os cidadãos da correção de suas propostas por meio da apresentação de relatórios com dados numéricos e estatísticos resumidos, muitas vezes, erroneamente. Podemos dizer que há interesse na força das ferramentas dessa ciência, pois seus resultados são interpretados nas tomadas de decisão em diversos contextos científicos, sociais, políticos, econômicos e tecnológicos.

Acreditamos, dessa forma, que os dois tipos de validações devem ser valorizados também em sala de aula - argumentações em e com Matemática -, pois privilegiar apenas um dos tipos empobrece a vivência dos estudantes no que diz respeito ao uso que poderão fazer de argumentações. Por exemplo, explicar que $5^{0}=1$ por meio de fatos concretos ou intuições, sem explicações intrínsecas àquelas das propriedades das potências, além de ser 
inútil, muitas vezes distorce a questão. De outra forma, no contexto da Geometria Plana, explicar ou provar que a soma dos ângulos internos de qualquer triângulo é $180^{\circ}$ remete à utilização de linguagem própria da Geometria, além de relações lógicas pertinentes. No primeiro caso, são as propriedades de potências que se quer preservar que justificam aquela igualdade, e no segundo caso, são fatos puramente geométricos que justificam o resultado. Por outro lado, extrair conclusões utilizando somente formalismos ou relações lógicas, pode implicar em uma análise incompleta da situação, produzindo uma conclusão errada. Como exemplo dessa situação, podemos pensar no PIB per capta que mede a distribuição de renda de um país. Supondo que um indivíduo queira estudar a qualidade de vida de uma população tendo como parâmetro a distribuição de renda (PIB per capta) de três países A, B e C, dispondo da informação que o PIB per capta de B é maior que o PIB per capta de A e que o PIB per capta de C é maior que o PIB per capta de B. A lei transitiva da igualdade permite concluir que o PIB per capta de C é maior que o dos outros países, porém não significa que a qualidade de vida da população desse país é melhor. Nesse caso, outras relações, além do uso do conhecimento matemático, são necessárias para se avaliar corretamente a questão. Deveremos aqui mobilizar tanto o significado, como certas regras implícitas que dependem da linguagem e das representações escolhidas para as passagens de uma proposição a outra. Diferentemente do raciocínio dedutivo, em que são utilizadas regras de dedução que estão dadas previamente.

Em suma, podemos intuir que para validar afirmações em Matemática (Matemática Pura) utilizam-se meios diferentes dos empregados para validar afirmações (ou tomar decisões) em contextos que fazem uso dessa ciência. Nesse último caso, questões do contexto enfocado precisam ser levadas em consideração. Assim, corroborando essa hipótese que fazemos sobre a valorização de argumentações matemáticas em diversos contextos além da própria Matemática, citamos uma metáfora de D'Amore: a dedução é semelhante a um cálculo, enquanto a argumentação se parece com um discurso. A passagem de uma argumentação a um raciocínio dedutivo válido não é automática. Além disso, segundo o autor, aprender a argumentar, em sua forma mais geral, não capacita diretamente o indivíduo a deduzir ou utilizar o método dedutivo. Assim, Duval (1992-1993, apud D'AMORE, 2007, p. 360), ao discorrer sobre a passagem da argumentação para a demonstração, chega à conclusão de que uma aprendizagem específica e independente é necessária no que diz respeito ao raciocínio dedutivo. Isso não significa que a argumentação não tenha seu lugar no ensino de Matemática. Ao contrário, deve ser igualmente tratada, exatamente para desenvolver competências argumentativas de forma mais abrangente. 
Historicamente, a Matemática produzida em diferentes épocas, por diferentes povos e grupos sociais, utilizou-se de linguagem específica para representar objetos matemáticos com métodos de validação de seus resultados variados, além do raciocínio lógico dedutivo. Em diversos campos de aplicações da Matemática, outras formas de raciocínio, além do raciocínio lógico dedutivo, são utilizadas como meio de validação em seus respectivos contextos, dentro de uma noção de rigor matemático apropriada aos seus contextos. O objeto matemático em estudo determina os tipos de pensamentos a serem utilizados e também cada tipo ou combinação de raciocínios é apropriado a uma classe de problemas, delimitando seu espaço de atuação. Por exemplo, na situação proposta em que desejava avaliar a qualidade de vida de uma população a partir do PIB per capta, a relação de transitividade mostrou-se inviável para fornecer uma resposta satisfatória. Em outro caso, em Álgebra, é inviável decidir, simplesmente pela enumeração de casos particulares, se a fórmula $n^{2}-n+41$ descreve uma lei que fornece a sequência de números primos (claramente falsa se substituímos n por 41), ou, nessa mesma direção, avaliar empiricamente se a expressão $x^{2}+$ $2 x+1$ representa um quadrado perfeito. No contexto da Geometria Plana, é necessário fornecer uma prova que convença os estudantes de que a soma dos ângulos internos de qualquer triângulo é $180^{\circ}$. Neste último caso, testes empíricos, em que os alunos são convidados a efetuar medições dos ângulos, demandam tempo. Além de ser necessário analisar as imprecisões das medidas, bem como a análise de vários exemplos de triângulos com tamanhos variáveis e formas, tudo isso não garante um nível de generalidade à prova, mas pode ser importante em um primeiro momento como motivação e investigação sobre as possíveis razões de ser o resultado válido em geral. Por fim, há que se levar em consideração a incerteza, presente em problemas que envolvem tomadas de decisões baseadas em um volume maciço de dados empíricos. Nesses casos, as validações desses raciocínios não determinísticos precisam ser baseadas em métodos estatísticos de análise de dados.

Assim, tipos diferentes de raciocínios podem ser usados para validar resultados, desde que sejam adaptados aos contextos e objetos de estudo em questão. Em Matemática, podem-se identificar quatro tipos (DRUCK, 2017): o raciocínio lógico dedutivo, o pensamento indutivo, o raciocínio ou visão geométrico-espacial e o pensamento não determinístico.

O raciocínio lógico tem caráter geral, pois os princípios da Lógica permeiam todos os campos do saber. Em Matemática, o raciocínio lógico dedutivo se caracteriza pelo emprego do método axiomático, sendo utilizado na sistematização e validação de teorias 
matemáticas. O método axiomático adota, como ponto de partida de uma teoria, noções primitivas e propriedades básicas sobre tais noções e relações fundamentais entre elas.

O pensamento indutivo ou método indutivo de pesquisa, próprio das ciências empíricas, apresenta-se no ato de criação matemática, onde a análise de exemplos, regularidades ou analogias, é suficiente para estabelecer um conhecimento empírico, o que pode gerar o levantamento de conjecturas gerais a serem validadas posteriormente. $\mathrm{O}$ raciocínio indutivo possibilita o fazer matemática por meio da experimentação, levantamento de hipóteses, análise de exemplos e adequação dos mesmos às conjecturas etc.

O raciocínio geométrico-espacial, proveniente da observação dos objetos, das relações entre eles e de seus movimentos no espaço físico, caracteriza-se pelo desenvolvimento de representações mentais dos mesmos. Assim, essa habilidade permite reconhecer, por visualização, características de figuras geométricas, interpretar relações entre objetos no espaço e estimar medidas de áreas e volumes sem medição direta, antecipar resultados de transformações de figuras planas e objetos espaciais, produzir e interpretar representações planas de objetos espaciais, plantas ou mapas. As validações nesse contexto podem ser baseadas em análises de figuras particulares ou na experiência do indivíduo como também se utilizar do método axiomático dedutivo. O desenvolvimento de visão geométrico espacial contribui para o domínio de noções como escala ou proporções, aplicar e compreender operações sobre figuras como os movimentos de reflexão, rotação ou translação, etc. Tudo isso, além de contribuir, significativamente, para a aprendizagem da Matemática, a visão geométrica espacial é fundamental em várias situações do cotidiano, nas ciências, nas artes e em diferentes profissões.

O raciocínio não determinístico, ou estatístico, envolve uma forma de pensar diferente dos outros campos da Matemática, no sentido de colocar o estudante diante de problemas cuja solução envolve incertezas ou imprevisibilidade na análise de fenômenos de natureza aleatória. Trata-se de um raciocínio que envolve tanto indução como dedução e leva em conta necessariamente a incerteza e a variabilidade. $\mathrm{O}$ raciocínio não determinístico, efetuado em exames médicos, decisões judiciais e até em investimentos financeiros, demanda a análise de erros. Tomar decisões em que o erro deve ser minimizado demanda a compreensão do conceito de variabilidade e a identificação das variáveis que atuam no fenômeno e suas relações para fins de realizar uma inferência. Saber enfrentar esses erros e compreender a variabilidade existente é fundamental para realizar inferências no mundo contemporâneo, permeado de informações estatísticas. Uma argumentação é um discurso que, em linhas gerais, fornece elementos para confirmar uma ideia que se quer defender - a 
tese. Em comum às argumentações com e em Matemática, é fato que toda argumentação demanda a utilização competente de linguagens apropriadas ao seu contexto. Assim, dado o nível de maturidade matemática dos interlocutores, a escolha e uso do simbolismo estão estreitamente relacionados ao tipo de conhecimento que se quer obter ou à informação que se deseja transmitir. De maneira mais específica, pode-se representar uma circunferência de raio 1 por meio de um disco de papelão, de um desenho feito com compasso ou da equação $\mathrm{x}^{2}+\mathrm{y}^{2}=1$. Por outro lado, um mesmo símbolo pode representar mais de um objeto matemático. Por exemplo, 20/100 pode indicar a fração $1 / 5$, a proporção "20 para 100", " $20 \%$, ou simplesmente indicar a medida 0,2 , conforme o contexto em que seja utilizado.

Tudo isso ilustra a importância de se ter cidadãos bem formados em Matemática básica, alfabetizados matematicamente, que sejam capazes de analisar criticamente os relatórios e declarações emitidas pelos políticos que os governam e, em geral, sobre qualquer decisão apoiada na Matemática (SKOVSMOSE, 2014, pp. 77-85).

É importante proporcionar experiências escolares que promovam o desenvolvimento desses quatro tipos de raciocínios ou intuições, sem privilegiar alguns em detrimento de outros, como a ênfase no exercício do raciocínio lógico. Para isso, em sala de aula de Matemática, é necessário que o educando se aproprie de linguagens específicas e dos significados dos símbolos, ao ponto de conseguir estabelecer relações entre os vários objetos simbólicos pertinentes à apropriação do conhecimento em foco. (GRANGER, 1979, p. 21 47, apud Duval, 2009, p. 16). Segundo D'Amore, tal apropriação é a base para estabelecer a comunicação.

Portanto, em um espaço de discussão ou debate crítico imerso em quaisquer ambientes de argumentações, em ou com Matemática, é necessário o conhecimento específico pelos interlocutores das diversas noções em jogo, bem como o domínio de seus raciocínios, para garantir a possibilidade de construção e avaliação das afirmações. Ao mesmo tempo, como área do conhecimento nos currículos da Educação Básica, há a necessidade de fazer com que o educando se aproprie dessa noção de rigor tão valorizada na sociedade atual.

Para isso, é importante assegurar, aos estudantes, o acesso e o domínio gradativo da linguagem matemática, em suas diferentes formas de expressão, o que envolve: ser leitor e produtor de textos matemáticos, ou seja, compreender, interpretar e comunicar-se por meio das terminologias e dos diferentes sistemas simbólicos que lhe são próprios, fazer uso adequado (oral e escrito) dessa linguagem nas diferentes práticas sociais e culturais. 
Do exposto até aqui sobre argumentações matemáticas, o caráter de rigor e precisão que essa ciência proporciona aos usuários da mesma está estreitamente ligado à ideia de validação, seja de questões intrínsecas à Matemática ou de outros contextos. A possibilidade da adequação dos métodos utilizados pelos pesquisadores matemáticos ao ambiente escolar pode motivá-los a buscar entender as diversas formas de se trabalhar Matemática, desde que isso possibilite aos estudantes de fato melhor compreenderem e se apropriarem dos vários usos do ferramental matemático em situações diversas.

$\mathrm{Na}$ próxima seção desta dissertação, à luz dos trabalhos de autores como Ole Skovsmose, Balacheff e Van Hiele, iremos tratar, entre outras, das questões seguintes.

- Como fazer com que os alunos se apropriem das noções de rigor em Matemática, conforme sugeriu Balacheff (1987), e que as utilizem nos diversos contextos sociais pertinentes?

- A utilização de linguagem precisa (simbólica ou não) e método lógico dedutivo que caracterizam o rigor e a precisão são as únicas formas de se considerar válido um resultado matemático?

- Quais tipos de atividades matemáticas podem ser propostas em sala de aula de tal forma que um trabalho com provas matemáticas (argumentação em Matemática) possa contribuir para o desenvolvimento do senso crítico? 


\section{Capítulo IV - Argumentações em Sala de Aula de Matemática da Educação Básica}

Baseados em trabalhos de pesquisadores como Skovsmose, Balacheff e Van Hiele, que veremos em detalhes a seguir, partimos do pressuposto de que o trabalho com validações no contexto da Educação Básica pode contribuir para o desenvolvimento dos tipos de raciocínios utilizados em Matemática e para a capacidade de argumentar. Para Skovsmose, discussões em sala de aula podem ser feitas com os alunos pelo estabelecimento de ambientes que envolvam tanto a Matemática pura quanto aquele presente no cotidiano, por meio de cenários de investigação. Em linhas gerais, Skovsmose propõe um trabalho que privilegie a abordagem de problemas pertinentes aos ambientes de aprendizagem referentes à Matemática Pura, à Semirrealidade, à Realidade e aos exercícios de fixação. Fato esse que utilizamos para justificar nossa posição de que se devem privilegiar outros tipos de raciocínios, além do lógico em um trabalho em sala de aula. Ele propõe ainda que o ensino de Matemática deve combater a Ideologia da Certeza e seu Poder Formatador (conceitos que definimos a seguir). Tudo isso, a nosso ver, contribui para a formação de um cidadão crítico. Balacheff propõe um trabalho específico com provas matemáticas (argumentação em Matemática), ressaltando a importância de que o aluno entenda a real necessidade de se estabelecer uma prova matemática. Para Balacheff é necessário, em sala de aula de Matemática, o fornecimento de dados externos, ou contraexemplos, que contrariem a percepção do educando, a fim de que ele compreenda a necessidade de uma prova de um fato matemático. Balacheff chamou de estabelecimento de uma gênese cognitiva para a necessidade de provas a qualquer dado externo oferecido ao aluno que contradiga seu entendimento sobre a situação. A exposição do aluno a esse elemento externo e que contradiz alguma concepção prévia, se incorporada pelos alunos, promove a necessidade de entendimento do caráter geral da situação e os move para o redirecionamento de elaboração de uma solução ou argumentação. Assim, segundo o autor, gerar um ambiente de questionamento e refutações em classe permite ao aluno refletir sobre seus conhecimentos prévios ou ingênuos do assunto, produzindo uma reorganização de pensamento. O modelo de desenvolvimento do pensamento geométrico de Van Hiele trata do ensino e aprendizagem da Geometria. Essencialmente, a teoria afirma que no processo de aprendizagem em 
Geometria, para poder realizar deduções de propriedades geométricas, o estudante passa por cinco níveis de pensamentos (do experimental ao abstrato) sequenciais e ordenados.

\section{IV.1 Ole Skovsmose, a Educação Matemática Crítica e Cenários para Investigação}

\section{Educação Matemática Crítica - Pressupostos}

A Educação Matemática Crítica, defendida por Skovsmose, é uma corrente de pensamento e uma tomada de posição diante das abordagens que influenciaram a Educação Matemática mundial, a saber, o estruturalismo, o pragmatismo e a matemática realística. $\mathrm{O}$ estruturalismo, base do Movimento Matemática Moderna, além de nortear os currículos, prioriza a absorção de conteúdo. O pragmatismo, tendência em Educação Matemática alternativa ao estruturalismo, enfatiza as aplicações dessa ciência, sobretudo fora dela. Já a matemática realística, corrente que tem Hans Freudenthal como expoente maior, concebe a Matemática como atividade humana natural e social, destacando a importância da ação do fazer matemática pelos estudantes. A primeira teve o propósito de oferecer aos alunos os conteúdos da teoria dos conjuntos, por serem estruturantes dessa ciência, buscando, em particular, propiciar um profundo entendimento da construção teórica da Matemática e sua estrutura lógica. A segunda prioriza a visão da Matemática como ciência aplicada, fornecedora de modelos para diversas situações em todas as áreas do conhecimento, do cotidiano e das práticas sociais. Nenhuma das duas atribui maior valor ao desenvolvimento da competência crítica dos educandos. Finalmente, a terceira enfatiza as atividades de ensino que proporcionam a estudantes oportunidades de criarem ou reinventarem matemática em sala de aula, de maneira a que possam desenvolver a capacidade natural de matematizar situações. Dessa forma, dentro dessa corrente de pensamento, há o desenvolvimento de senso crítico e dos tipos de raciocínios matemáticos, contribuindo, mais claramente, para a formação integral do educando (SKOVSMOSE, 2013, pp. 13-35).

Na formulação dos pressupostos da Educação Matemática Crítica, Skovsmose critica o ensino de Matemática baseado apenas na prática repetitiva de exercícios, o que ele denomina de paradigma do exercício (ALRø, 2010, p. 54): aplicações de fórmulas ou rotinas preestabelecidas e sem exigir reflexão por parte do estudante, com a posterior 
enumeração de acertos numa avaliação. Segundo Paulo Freire (1996, p. 52), a repetição, e a consequente memorização, de procedimentos mecânicos não estimulam a curiosidade, tampouco o real aprendizado. Quanto ao ensino de Matemática, além de dar uma falsa impressão de aprendizagem, tal prática não leva em consideração a dimensão social e crítica que o ensino de Matemática pode e deve oferecer na formação do educando. Nesse sentido, como alternativa a essas correntes da Educação Matemática, Skovsmose propõe a conjunção da Educação Matemática Crítica- integrando as mesmas (Estruturalismo, Pragmatismo e Realismo) - com a Educação Crítica, defendida por Paulo Freire. Educação Crítica é aqui entendida como uma concepção de educação para cidadania (FERNANDES, 2011, p. 43).

\section{A Ideologia da Certeza e o Poder Formatador da Matemática}

Para Skovsmose, a Educação Matemática Crítica, como uma teoria geral da Educação, "tem como pressuposto básico que a educação não deve servir como reprodução passiva de relações sociais existentes e de relações de poder". Sua função, num contexto de uma sala de aula, é identificar os reais problemas sociais e combatê-los por meio do desenvolvendo da competência e o engajamento críticos atuando paralelamente a outras forças para promover mudanças sociais. Essa corrente educacional tem como pressuposto a existência da Ideologia da Certeza e do poder formatador da Matemática, para poder criticálos. A primeira consiste no uso de ferramental matemático como argumento definitivo para validar conhecimentos em qualquer área. E o segundo refere-se à tomada de decisão baseada em modelos matemáticos, que, muitas vezes, submetem a realidade aos modelos (SKOVSMOSE, 2013, pp. 127-130). Por exemplo, o IDESP - Índice de Desenvolvimento da Educação Básica do Estado de São Paulo -, determinado a partir do fluxo de alunos aprovados e de provas de larga escala, é utilizado pela Secretaria de Estado da Educação como indicador da qualidade do ensino das escolas públicas de São Paulo, com premiação para as escolas que aumentam seu índice de um ano para o outro. Na prática, muitas escolas passaram a controlar as variáveis na composição do índice, ao invés de investirem na formação integral dos estudantes, com qualidade. Nesse caso, o IDESP pode ser visto como um modelo matemático ao qual a realidade educacional é submetida, passível de ser manipulado, deixando de ser uma medida efetiva da qualidade do ensino.

Como tomada de posição, A Educação Matemática Crítica tem o objetivo de combater a Ideologia da Certeza e O poder formatador da Matemática (SKOVSMOSE, 2013, p.135). O primeiro consiste no poder de decisão ou do argumento definitivo, validando 
conhecimento em qualquer área quando se usa uma de suas ferramentas matemáticas, e o segundo refere-se à tomada de decisões baseadas em modelos matemáticos; e, ainda, à convicção de que o modelo descreve a realidade, submetendo esta aos modelos matemáticos. O IDH (Índice de Desenvolvimento Humano) é um exemplo de modelagem matemática que é decisiva em situações de decisões políticas. Como o valor desse índice é calculado com base em variáveis que remetem ao desempenho em Educação, Renda e Saúde, justifica-se o investimento em uma ou outra área para garantir o aumento do IDH ou também aponta a direção dos investimentos em determinadas áreas e regiões.

Outros exemplos se configuram na utilização frequente de índices como o IDEB (Índice de Desenvolvimento Para a Educação Básica), modelos matemáticos que expressam a distribuição de renda como o PIB per capta e as porcentagens. Em geral, não há um questionamento sobre como as variáveis que compõem um índice influenciam a elevação ou diminuição do mesmo. No modelo expresso pelo PIB, países árabes, ricos em petróleo, possuem um PIB per capta altíssimo, porém, na realidade, a riqueza está concentrada com uma pequena parcela da população; com relação às porcentagens, um exemplo que posso citar são as notícias que visam desmerecer movimentos grevistas como "só $20 \%$ dos professores estão em greve”. O público leigo claramente entenderá a mensagem como “poucos professores estão em greve", pois ainda existem $80 \%$ trabalhando.

\section{Cenários para Investigação}

A comunicação exerce papel fundamental na prática do ensino e da aprendizagem. $\mathrm{O}$ exercício do diálogo a ser praticado entre professor e aluno em sala de aula se distancia da prática de exercícios rotineiros e estimula a curiosidade. Além disso, ao considerar esse tipo de comunicação em sala de aula, o professor estará contribuindo para o desenvolvimento do senso crítico do educando. Ou seja, nas palavras de Paulo Freire (1996, p. 52): “[ ...] a construção ou a produção do conhecimento do objeto implica o exercício da curiosidade, sua capacidade crítica de "tomar distância" do objeto, de observá-lo, de delimitá-lo, de cindi-lo, de 'cercar' o objeto ou fazer sua aproximação metódica, sua capacidade de comparar, de perguntar".

Alrø e Skovsmose afirmam que o tipo de comunicação em sala de aula determina o tipo de aprendizagem de Matemática. Nas palavras dos autores, "as qualidades da comunicação na sala de aula influenciam as qualidades da aprendizagem de Matemática" (ALRø, 2010, p. 11). De forma resumida, em se tratando do ensino de Matemática, os 
autores dizem que certas qualidades de comunicação, que tentamos expressar em termos de diálogos, favorecem certas qualidades de aprendizagem de Matemática (ALRØ, 2010, p. 19). A abordagem pedagógica de Paulo Freire (1996, pp. 74-75) por exemplo, ilustra a importância da qualidade da comunicação para a aprendizagem. Segundo esse autor, as discussões em sala de aula devem pôr em pauta as pessoas e seu espaço social de convivência. Os conteúdos das disciplinas são vistos por ele como meios para obter conhecimento. Esse padrão de comunicação é o cerne de uma educação que leva à emancipação dos educandos. No referencial de qualidade de aprendizagem que Freire desenvolveu, os alunos não devem somente aprender a ler e a escrever, mas sim interpretar criticamente a situação social e política. Em contrapartida, a transmissão de conhecimentos prontos que não exigem a reflexão por parte do aluno tende a produzir um aluno passivo (FREIRE, 1996, p. 68), (ALRØ, 2010, p. 18). Todo o processo de comunicação é alicerçado em um referencial sobre o qual as afirmações ganham sentido, o qual Skovsmose chama de perspectivas (ALRØ, 2010, pp. 28-29). Em linhas gerais, sua proposta educacional faz referência a uma variedade de perspectivas que dizem respeito a aspectos sociais e políticos do aprendizado em Matemática, acesso das ideias matemáticas a todos, independentemente de sexo, cor, classe social, etc., uso e função da Matemática (aplicações tecnológicas avançadas ou na vida cotidiana), vida em sala de aula (que deveria representar um espaço democrático onde as ideias são apresentadas e negociadas), e desenvolvimento de um cidadão crítico.

Assim, na proposta da Educação Matemática Crítica, Skovsmose (2014) defende o oferecimento de ambientes de ensino e aprendizagem de modo a incluir o desenvolvimento da competência de analisar e avaliar criticamente como a Matemática, presente nas diversas práticas sociais, influencia o desenvolvimento cultural, tecnológico e político, além de valorizar os processos que permitem ao educando o aprendizado mais eficiente de conceitos e ideias matemáticas (ALR $\varnothing, 2010$, p. 18). Em suma, Ole Skovsmose defende que, em sala de aula, sejam articulados conhecimentos que habilitem o educando a reconhecer como a Matemática aparece nos contextos políticos e econômicos, combatendo assim a Ideologia da Certeza e o Poder Formatador da Matemática (conceitos já definidos no capítulo anterior). Com o objetivo de abordar o ensino de Matemática em um contexto que integre as correntes de pensamento em Educação antes citadas (como as perspectivas enumeradas 
antes), Skovsmose propõe uma prática escolar com o estabelecimento de ambientes de ensino e aprendizagem que ele denomina de cenários para investigação.

Um cenário para investigação é um ambiente que pode dar suporte a um trabalho no qual os alunos se envolvem em um processo de exploração e argumentação justificada, fazendo-os refletirem e agirem sobre a situação proposta. É um ambiente que dá suporte à prática da pesquisa e investigação, contrastando com práticas baseadas somente em exercícios. A proposta de ensino de Matemática alicerçado em um cenário para investigação matemática compreende a apresentação ao educando de problemas artificiais e problemas de situações reais, além da prática de exercícios. Os problemas propostos devem ser abertos o suficiente, de forma que os alunos possam formular questões e planejar linhas de investigação de maneira diversificada, apresentando justificativas e argumentos para suas tomadas de posição em relação à questão proposta, cabendo ao professor a mediação das mesmas. Tal não ocorre em atividades nas quais prevalece a execução de exercícios rotineiros e onde os problemas não admitem mais de uma estratégia de resolução e nenhuma ou mais de uma resposta correta (SKOVSMOSE, 2014, p. 54).

Para criar cenários para investigação pode-se recorrer às mais diversas fontes, como notícias de jornal constantes da área econômica, com sua enorme quantidade de dados, por exemplo. Numa hipotética situação de redução de alíquota de algum imposto, poder-se-ia propor aos alunos que estudassem o impacto na arrecadação devido a essa redução. Em uma perspectiva que vá além dessa, conforme diz Skovsmose (SKOVSMOSE, 2014, p. 57), outras avaliações poderiam ser feitas a partir dessa notícia: qual é a arrecadação total de impostos no Brasil? Quanto se sonega? Qual o destino dos impostos arrecadados? Obviamente, deve-se observar a maturidade dos estudantes ao oferecer esses questionamentos, pois alguma pesquisa e cálculos devem ser feitas. Em outra situação, a crise hídrica pela qual passou o Estado de São Paulo em 2015 ofereceu um cenário para investigação por meio do qual desenvolvemos o nosso segundo experimento didático (ver capítulo VII). Cabe ao professor, nessa situação, convidar os alunos a discutirem quanto de água eles e suas famílias utilizam para banho. Seu gasto total de água é alto ou baixo em sua opinião? Quanto de água é destinado para banho e para lavagem de roupa? Novamente, os alunos devem ser convidados a responder a essas questões. De modo geral, o trabalho com computadores em sala de aula, por exemplo, fornece um cenário para investigação. Um software de geometria dinâmica permite aos alunos explorarem questões inerentes à própria Matemática, como propriedades das reflexões, rotações e translações, bem como investigarem propriedades de figuras geométricas. Com planilhas eletrônicas, os alunos 
podem investigar a convergência de séries numéricas, tabular e efetuar cálculos sobre dados numéricos para fins de controle de um estoque fictício (semirrealidade) ou verificar, no decorrer de um ano, a evolução de seu consumo de energia elétrica (realidade). Também podemos propor cenários para investigações caracterizados por um alto grau de referência a de semirrealidade (situações artificiais) ou situações da vida real. Exemplos disso, respectivamente, são atividades que incluam compras de quantidades absurdas de determinadas frutas por determinado valor unitário, viagens de carro em que, dada a relação volume de combustível por quilômetro rodado, pede-se para calcular o volume de combustível gasto para fazer a viagem, etc.; e, finalmente, trabalhos em atividades referentes a situações da vida real e questões puramente matemáticas, como o uso de ferramentas ou ideias da Matemática para resolverem exercícios ou problemas em contextos internos à própria ciência.

Dada a distinção das ideias ou contextos matemáticos nesses três tipos de referência e combinadas aos paradigmas de práticas de sala de aula, Skovsmose elaborou uma matriz com seis tipos diferentes de ambientes de aprendizagem (SKOVSMOSE, 2014, p. 54).

\begin{tabular}{|l|c|c|}
\hline & Exercícios & Cenários para Investigação \\
\hline Referências à Matemática Pura & $(1)$ & $(2)$ \\
\hline Referências à Semirrealidade & $(3)$ & $(4)$ \\
\hline Referências à Realidade & $(5)$ & $(6)$ \\
\hline
\end{tabular}

Ambiente tipo (1): é o ambiente dominado por exercícios apresentados no contexto da Matemática pura, como lista de exercícios com expressões numéricas, aplicações de algoritmos, etc.

Ambiente tipo (2): caracterizado como um ambiente que, ao envolver, por exemplo, números ou figuras geométricas, promove-se a busca e não há o exame das propriedades das figuras em si, mas sim o exame de padrões de divisibilidade de números inteiros ou a investigação dos casos ou critérios de congruência de triângulos utilizando dobradura.

Ambiente tipo (3): constituído por exercícios com referências à semirrealidade, em que os problemas propostos tratam de compras ou vendas de frutas, imóveis, descontos, juros sobre dívidas, etc. São problemas que fazem apelo a situações corriqueiras em uma sociedade, 
porém, não necessariamente fazendo parte da realidade de quem os está resolvendo. Sendo, por isso, uma situação artificial. Os dados fornecidos oferecem um suporte para a resolução do problema por meio dos procedimentos anteriormente expostos pelo professor. Isso provoca a impressão de que a resolução e a resposta são únicas.

Ambiente (4): nele trabalha-se também uma semirrealidade, mas a execução de exercícios é substituída por um ambiente de exploração e investigação. Como exemplo, podemos citar a situação em que os alunos são convidados a investigar qual a rota de entrega de mercadorias que minimiza, simultaneamente, tempo, distância e combustível.

Ambiente (5): neste ambiente são oferecidos dados da vida real. Como exemplo, podemos citar a apresentação de gráficos estatísticos e questionários sobre os mesmos, ou propor problemas de cálculo a partir de uma lista de preços unitários baseados em um folheto de supermercado.

Ambiente (6): neste caso, podemos citar a proposta de uma atividade que contextualiza o estudo das razões e proporções a partir de dados do consumo de água doméstico (residencial), industrial e agrícola. Pode-se perguntar qual segmento demanda maior quantidade de água. Uma posterior contribuição desse estudo seria levantar a questão da responsabilidade social das empresas no que se refere ao seu papel da reutilização da água.

Os ambientes (1), (3) e (5) representam o paradigma do exercício, com (1) e (3) predominando no ensino e influenciando de forma decisiva os padrões de comunicação entre professor e aluno. Os ambientes (2), (4) e (6) representam cenários para investigação nas três possíveis formas de referência de produção de significado pelos estudantes. Essas referências podem auxiliar o posicionamento dos alunos na medida em que propiciam visão geral do que pode ser feito. Nos ambientes (1) e (2), as referências são feitas somente à matemática pura. Em (3) e (4), as referências são feitas à semirrealidade, ao passo que (5) e (6), incluem referências ao mundo real. O modelo proposto evidencia o fato de que diferentes cenários correspondem a ambientes de aprendizagem diferentes, assim como o mesmo cenário pode atender diferentes ambientes de aprendizagem.

Diante do exposto, pode-se concluir que Skovsmose propõe ser necessário que o professor transite por todos os ambientes de investigação citados anteriormente em sua abordagem de ensino, para promover o desenvolvimento da capacidade dos estudantes de refletirem sobre o papel da Matemática na sociedade atual (SKOVSMOSE, 2014, p 60). Segundo o autor, a mudança do padrão de comunicação em sala de aula está estreitamente 
ligada à mudança do paradigma do exercício para o cenário de investigação, sendo a transição pelos diversos referenciais citados que conduz a uma reorganização de pensamento e leva os estudantes a produzirem significados para conceitos e atividades matemáticas.

No entanto, embora a proposta de um cenário seja um convite para que os alunos se envolvam em um processo de investigação, pode não ser muito atrativa para muitos a possibilidade de explorar e explicar assuntos de Matemática pura. Por exemplo, como convidar o aluno a construir a validação de um resultado matemático? Como fazê-lo entender a necessidade de construir uma prova?

A seguir, tratamos de responder a essas questões. Assim, vamos identificar quais processos de investigação podem ser feitos, ou mais especificamente, que ambientes de investigação concorrem para o estabelecimento do aprendizado de validações matemáticas, à luz de trabalhos de Balacheff.

\section{IV.2 Nicolas Balacheff e os diferentes tipos de validações matemáticas}

No campo acadêmico, a intuição e o método dedutivo são necessários para a construção do conhecimento matemático. A intuição é fortemente utilizada durante a construção do conhecimento, ou seja, na fase de descoberta, em que há a formulação de hipóteses, testes empíricos, elaboração de conjecturas, etc. Já a dedução é o modo utilizado pelo matemático para validação e comunicação dos resultados intuídos e, para isso, faz uso de ferramental lógico pertinente. Do nosso ponto de vista, a diferenciação entre intuição e dedução é essencial para um ensino que vise a formação integral do educando, pois, embora apresentem finalidades distintas, ambas têm como pressuposto o estabelecimento de relações entre os diversos objetos em estudo para obtenção de conclusões sobre eles. Segundo Fischbein (apud D'Amore, 2007, pp. 333-334), a intuição faz uso de "um conjunto de representações, de relações, de interpretações, de imagens, até mesmo de descrições proposicionais que o sujeito que aprende considera como certas" e que embasam ou justificam o novo conhecimento.

Argumentações utilizadas em Matemática têm o propósito de validar ou refutar afirmações, verificar ou esclarecer resultados. Podem utilizar raciocínios lógico, indutivo, ou estatístico, e a discussão de exemplos ou contraexemplos, em explicitações de provas ou demonstrações. Em particular, as provas matemáticas, sobretudo aquelas de caráter puramente dedutivo, possuem tripla importância para os matemáticos profissionais: revelar, no decorrer de suas construções, as relações lógicas implícitas entre afirmações, justificar a 
validade do resultado e registrar resultados para serem avaliados entre pares e contribuírem para o acúmulo de conhecimentos desta ciência. A construção de provas tem a função social de comunicar resultados matemáticos a um determinado grupo de interessados. Em uma sala de aula, argumentos matemáticos, com metodologia de ensino pertinente, podem ser utilizados pelo professor com o mesmo tipo de função que possuem em contexto acadêmico (DE VILLIERS, 1999; GIANNAKOULIAS et al, 2010).

A partir do conhecimento das funções de uma demonstração, nosso objetivo é entender, nos termos de Balacheff, como as mesmas podem ser trabalhadas em sala de aula. Inicialmente, é importante esclarecer e refutar argumentos correntes de que a dificuldade dos alunos em aprender e produzir provas é devido ao baixo desenvolvimento cognitivo ou falta de competência no raciocínio lógico. Contradizendo Piaget, estudos mostram que crianças muito novas são inteiramente capazes de fazer raciocínios lógicos em situações reais. Por outro lado, pesquisas mostraram que o ensino de Lógica aos alunos não conduziu a estatísticas significativas no que diz respeito à melhoria na capacidade ou atitude em demonstrar (WALTER,1972 apud DE VILLIERS, 1999). Assim, é necessário investigar quais condições didáticas podem viabilizar um trabalho com provas na Educação Básica.

Em seus trabalhos, Balacheff faz um estudo sobre as condições didáticas a serem garantidas em sala de aula de Matemática para o estabelecimento de uma gênese cognitiva do processo de prova pelos educandos.

O autor afirma, em linhas gerais, que as validações matemáticas praticadas no âmbito escolar devem ser desenvolvidas de forma a atender o nível de maturidade matemática do grupo social da sala de aula. Primeiramente, esclarece que aos alunos da Educação Básica não é necessário o compartilhamento da linguagem e rigor requerido nas demonstrações feitas pelos matemáticos profissionais, que as utilizam como discursos para comunicação entre pares (BALACHEFF, 1987). Uma validação rigorosa atende às necessidades de comunicação na comunidade dos matemáticos, possibilitando a criação de um fórum para debate crítico entre seus membros. Portanto, no âmbito escolar, também a construção de provas rigorosas deve ser fruto de um debate crítico entre os alunos, o que demanda a utilização de uma linguagem acessível ao nível de escolaridade e que respeite uma noção de rigor compatível com o dessa ciência (BALACHEFF, 1987).

Para o estabelecimento de sua teoria, Balacheff diz que um obstáculo ao trabalho com validações matemáticas em sala de aula ocorre pelo fato de que palavras como "prova", "demonstração" e "raciocínio" são comumente tratadas como sinônimos pelos matemáticos e também por professores. Isso constitui um obstáculo para as investigações sobre a 
implementação do ensino de provas na Educação Básica por provocar o falso entendimento de que o método axiomático é o único a ser a aceito em âmbito escolar. Assim, o autor clarifica essas questões de vocabulário. Além disso, considera importante a distinção dos significados de tais termos para o estabelecimento de condições didáticas facilitadoras do processo de tomada de consciência de uma validação por parte dos educandos. Seguem as definições introduzidas por Balacheff (1987):

Explicação: discurso que visa explicitar as razões pelas quais o locutor está convencido da verdade de uma proposição ou de um resultado. As razões invocadas podem ser discutidas, refutadas ou aceitas.

Prova: explicação aceita por uma determinada comunidade num momento dado. Essa aceitação pode ser objeto de um debate, sem a exigência, pelos interlocutores, do uso de um sistema de validação geral ou pré-fixado.

Demonstração: prova que consiste em uma sequência de enunciados organizados convenientemente por regras convencionadas pela totalidade dos especialistas da área em questão. Na comunidade matemática, as demonstrações aceitas são aquelas que seguem o método axiomático, baseado na lógica subjacente considerada (em geral a Lógica Clássica). Um enunciado é tido como verdadeiro, ou bem deduzido a partir de enunciados precedentes, se for obtido a partir das premissas com o emprego de uma regra de dedução de consenso, ou seja, por meio de um conjunto de regras bem definidas dentro da Lógica.

A palavra raciocínio é utilizada para designar a atividade intelectual de um indivíduo, frequentemente não explícita, por meio da qual elabora o processamento de dados ou informações para deles extrair conclusões.

Corroborando essa distinção sugerida por Balacheff, Hanna (1990) faz uma discussão sobre o papel das validações em Matemática e a abordagem pelos próprios matemáticos de sua percepção de rigor, aceita em suas demonstrações. Assim, faz a distinção entre provas formais e provas aceitáveis.

Provas Formais de um enunciado matemático (tese) são procedimentos mecânicos, baseados estritamente em princípios da Lógica Formal, que têm por função eliminar aspectos psicológicos, recursos à intuição, o julgamento ideológico, arbitrário ou pessoal de sua construção. Uma prova formal é uma sequência finita de afirmações onde a primeira é um axioma, cada uma das seguintes pode ser também um axioma ou uma afirmação deduzida de sentenças anteriores por meio do uso de regras de inferência, sendo a última o enunciado a ser provado. Provas Aceitáveis são também sequências de enunciados, mas que não explicitam todas as passagens do raciocínio feito. Várias das conexões lógicas entre 
enunciados ficam implícitas, considerando-se que o leitor/interlocutor tenha experiência suficiente para preencher as lacunas. Assim, apesar de não possuírem o mesmo desenvolvimento rigoroso de uma prova formal, são igualmente aceitas pelos matemáticos. Como o primeiro tipo é muito árido, o segundo, de leitura mais acessível, é considerado válido pelos matemáticos, na medida em que puder ser transformada em prova formal. Assim, a distinção entre provas formais e provas aceitáveis, na prática profissional do cientista matemático, orienta o argumento que os educadores matemáticos utilizam para adaptar as validações ao contexto do ensino.

Partindo da noção de provas aceitáveis, educadores matemáticos buscam ressignificar o papel das validações no âmbito do ensino de maneira a atender ao grupo social da sala de aula como um todo. Investigações sobre a adequação das provas não formais ao contexto de Educação Básica indicaram que o ensino de provas deve referir-se ao reconhecimento de sua função como argumento convincente. Nesse sentido, por exemplo, Balacheff diz que uma prova de que a soma dos ângulos internos de um triângulo é $180^{\circ}$ pode ser dada por meio do recorte dos ângulos de um triângulo e justapondo-os conforme a figura a seguir:
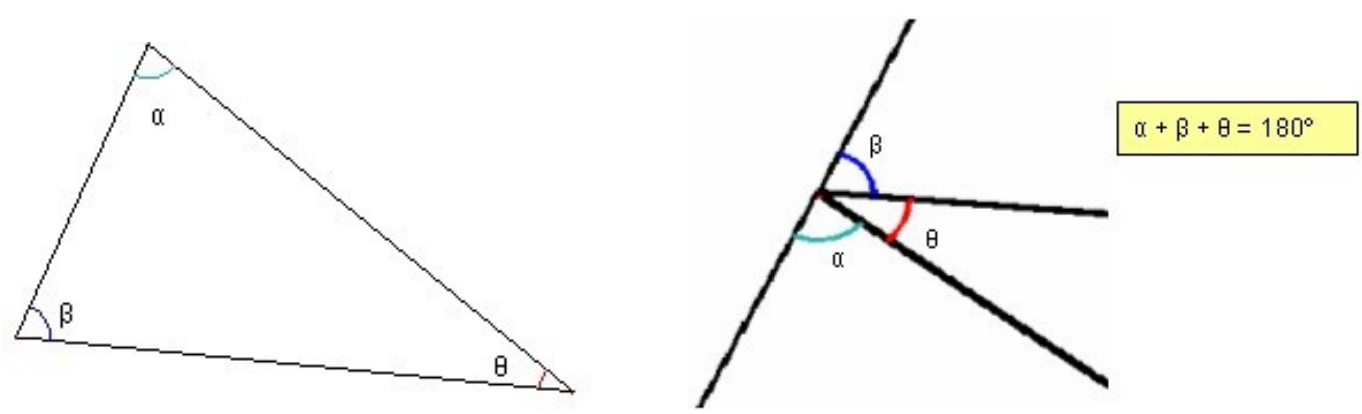

Figura 1 Prova da soma dos ângulos internos de um triângulo

Por outro lado, a demonstração pode empregar linguagem e métodos mais rigorosos, como aquela que faz uso do teorema das paralelas cortadas por uma reta transversal, na dependência do nível de maturidade do público alvo.

DEMONSTRAÇÃO:

1. Construir um triângulo $\mathrm{ABC}$ qualquer

2. Construir a reta $r$ passando por B paralela ao lado AC

3. O ângulo x é congruente a $ß$ (correspondentes) 
4. O ângulo y é congruente a ø (alternos internos)

Como $\varnothing+\mathrm{x}+\mathrm{y}=180^{\circ}$, por 3 e 4 , concluímos que $\varnothing+\beta+\mathrm{p}=180^{\circ}$

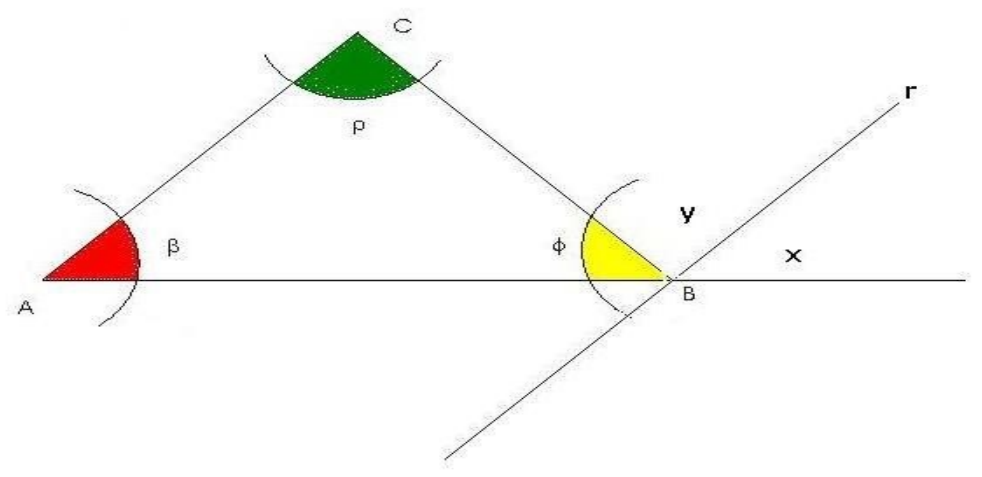

Figura 2 Prova da soma dos ângulos internos de um triângulo pelo teorema das paralelas

Portanto, abordar as validações na Educação Básica conforme o fazer dos matemáticos, oferece ao educando a possibilidade de conjecturar, formular hipóteses, testar, comparar, refutar, validar, comunicar sua descoberta por meio da construção de argumentos e, além disso, ampliar seu conhecimento. Assim, a questão a ser discutida é: como trabalhar a construção de provas em sala de aula de Matemática de maneira a promover a construção do conhecimento, tornando-as significativas para o educando, e contribuindo para a sua Formação Integral?

As definições fornecidas por Balacheff (1987) indicam que são as explicações e as provas os tipos de validações que devem ser trabalhadas em sala de aula, principalmente no Ensino Fundamental. São elas que permitem o desenvolvimento dessa habilidade de pensamento primordial em Matemática, por meio da exposição constante dos alunos à construção destes dois tipos de argumentações. Ao mesmo tempo elas podem contribuir, conforme disse Carraher, para que o indivíduo se aproprie e exercite a competência argumentativa e a crítica em espaços que extrapolam a Matemática (CARRAHER, 2011, p 14). No entanto, em geral no ensino, práticas essenciais que favorecem o aprendizado de provas pelos alunos são substituídas pela prática de exercícios repetitivos. Deixa-se de lado a proposição de atividades que exigem a apresentação de argumentos com justificativas pelos estudantes, eventualmente abusando de "validações" justificadas meramente pela apresentação de alguns testes empíricos que não exigem qualquer reflexão por parte do educando durante suas execuções. Para Balacheff (1987), essas práticas constituem 
obstáculos ao entendimento da necessidade de validar afirmações pelos alunos da Educação Básica.

No âmbito da construção da Matemática como ciência, uma demonstração tem o objetivo de comprovar a validade ou não de uma afirmação, e juntamente com sua metodologia própria garantir a ausência de contradições formais e semânticas no argumento. Dessa forma, um trabalho com provas matemáticas a ser desenvolvido em sala de aula precisa ser realizado de modo que, durante a Educação Básica, o estudante se aproprie do entendimento da necessidade de garantir a ausência de contradições (formais e semânticas) em seus argumentos. Segundo o autor, observar os níveis de prova por ele definidos nas atividades propostas favorece o entendimento da necessidade de validações por parte dos alunos. Para nós, esse processo de desenvolvimento concorre para a Formação Integral do Estudante.

A abordagem das provas no contexto da Educação Básica deve ser feita de tal modo que convença os alunos da validade da solução do problema não só do ponto de vista de métodos axiomáticos. A validação nesse caso será um procedimento que confere a verdade da afirmação, cuja conviç̧ão foi obtida com recursos da intuição ou empiricamente. E a explicação consiste na argumentação sobre as razões da veracidade de um resultado (DE VILLIERS, 1999).

Por exemplo, podemos determinar e comprovar o valor da soma dos $n$ primeiros números naturais ímpares por meio de uma visualização geométrica. É imediata a constatação do valor dessa soma para os primeiros números ímpares, como mostra a figura a seguir. Por raciocínio indutivo, podem-se levantar hipóteses sobre a generalização do resultado, o que não é evidente nesse tipo de representação.
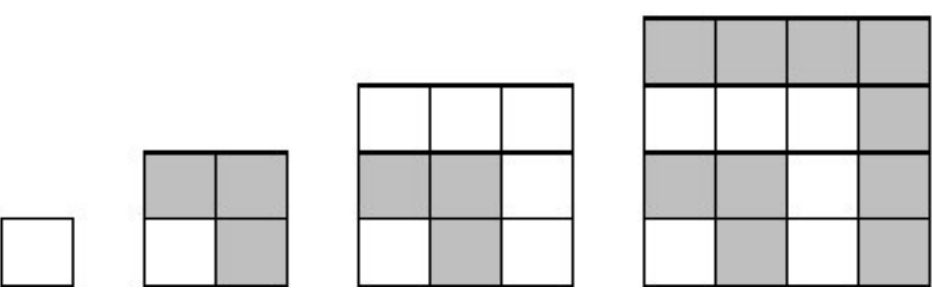

Figura 3 Soma dos n primeiros ímpares naturais. Fonte: Balacheff, 1988

Nesse caso, a linguagem matemática não é determinante para a transmissão do conhecimento e para o convencimento, pois basta o aluno observar que em cada elemento da sequência, respectivamente, aparecem as somas $1,1+3,1+3+5$ e $1+3+5+7$, determinando 
um quadrado. Por raciocínio indutivo, pode-se tentar levantar hipóteses sobre a generalização do resultado. Como forma de fornecer um impulso para essa busca, o professor pode perguntar, por exemplo: se quisermos somar os ímpares de 1 a 17, qual seria o lado do quadrado e qual seria a sua área? Os alunos poderão perceber a regularidade geral: para achar a soma de $n$ números ímpares, podemos arranjá-los em um quadrado de lado $n$, cuja área, $n^{2}$ expressa a soma buscada.

A prova da validade desta última hipótese genérica só é acessível em contextos minimamente de Ensino Médio, pois demanda outros conhecimentos, quer sobre progressões aritméticas (e suas somas), quer sobre o Princípio da Indução Finita, para a demonstração matemática da validade de propriedades gerais sobre os números naturais.

No entanto, pode também caber no Ensino Fundamental a discussão do mesmo problema por meio de registro aritmético/algébrico. Já que os números ímpares são da forma " $2 \mathrm{n}-1$ ", com $n$ número natural, pode-se buscar uma hipótese geral para o valor das somas utilizando também seus registros aritmético/algébrico e buscando encontrar regularidades:

$$
\begin{array}{lr}
1=(2.1-1) & 1=1=1^{2} \\
1+3=(2.1-1)+(2.2-1) & 1+3=4=2^{2} \\
1+3+5=(2.1-1)+(2.2-1)+(2.3-1) & 1+3+5=9=3^{2} \\
1+3+5+7=(2.1-1)+(2.2-1)+(2.3-1)+(2.4-1) . & 1+3+5+7=16=4^{2}
\end{array}
$$

Eventualmente, um estudante mais atento e motivado, poderia intuir, a partir da generalização $1+3+5+7+\ldots+n_{\text {ésimo_impar }}=n^{2}$, mesmo a demonstração sendo inacessível,

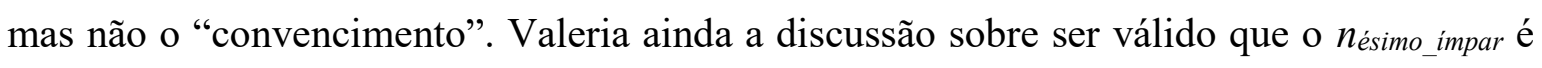
da forma $2 n-1$, para a obtenção de uma expressão em linguagem algébrica, já que, nesse caso, o raciocínio indutivo é necessariamente baseado nela.

No Ensino Médio, os alunos podem observar que a soma $1+3+5+\ldots+2 \mathrm{n}-1$ pode ser calculada por meio da soma dos $n$ primeiros termos de uma progressão aritmética.

Ou seja:

$$
\sum_{i=1}^{n} 2 i-1=\frac{n(2 n-1+n)}{2}=\frac{n \times 2 n}{2}=n^{2}
$$

A construção da forma geométrica do quadrado, na primeira argumentação, e a observação indutiva de que essas somas aparecerão nas figuras subsequentes, são fundamentais para a confirmação do resultado. Já na segunda abordagem, exige-se e promove-se uma familiarização com o uso de linguagem algébrica. Provas como as 
esboçadas nesses casos são chamadas por Balacheff, respectivamente, de provas pragmáticas e conceituais. As primeiras são assim chamadas por demandarem o uso de ação e observação sobre o objeto para serem confirmadas. Nesses casos os alunos estabelecem conjecturas a partir de situações particulares, sem estabelecerem generalizações das mesmas. Em contrapartida, nas provas conceituais, os alunos baseiam-se em formulação de propriedades pertinentes e relações entre elas, como as realizadas no interior do estudo de progressões aritméticas (que utilizam propriedades das mesmas para estabelecer a fórmula da soma de termos) ou em procedimento que utilize o Princípio da Indução Finita (em que as propriedades algébricas dos números e as relações entre as mesmas determinam o rumo da prova) (BALACHEFF, 1988).

As provas pragmáticas, portanto, são aquelas em que o aluno valida uma afirmação utilizando linguagens e outros recursos que estão restritos ao problema em questão, falhando, possivelmente, no caráter geral. Já as provas conceituais requerem a formulação de argumentos por meio de expressões linguísticas que descrevam os objetos do problema e suas relações.

É importante que seja feito um movimento das provas pragmáticas para as provas conceituais por parte do aluno. Isso ocorre pela transposição de uma linguagem não precisa, mas pertinente apenas à comunicação de resultados, para uma linguagem que permita explicitar conclusões ou inferências e não apenas comunicar convicções. Como exemplo de uma atividade a ser proposta e que estimule esse movimento, podemos citar a validação do enunciado que afirma que a soma dos ângulos internos de um triângulo é $180^{\circ}$. Em um primeiro momento, usando transferidor, podemos "testar" casos particulares para comprovar que as somas das medidas dos ângulos é $180^{\circ}$ para vários tipos de triângulos. Em outro cenário, outra situação de prova da mesma afirmação pode ser proposta. A partir de um triângulo desenhado em uma folha de papel, pode-se solicitar que os alunos façam recortes que possibilitem colocar os três ângulos de forma adjacente com seus vértices (idealmente) no "mesmo" ponto, de maneira que componham um ângulo raso.
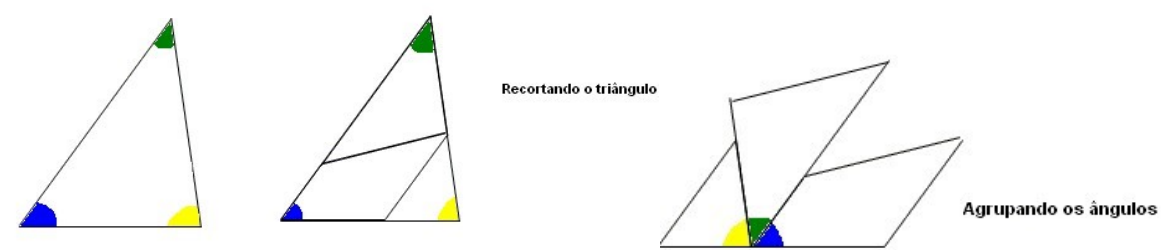

Figura 4 Prova pragmática para a soma dos ângulos internos de um triângulo 
No primeiro método de validação adotado, uma situação de explicação é evidente, pois alguns testes empíricos podem evidenciar o resultado matemático exato ou aproximado, podendo ser levantada a dúvida sobre o caráter geral do resultado devido à impossibilidade de medidas exatas na prática. No segundo método, há uma situação de prova pragmática, mas com potencial de ser transformada em prova conceitual, pois possibilita a transposição da validação de casos particulares à validade em geral, por utilizar, na prática, a ideia matemática essencial da demonstração. A possibilidade de composição dos ângulos para formar um ângulo raso é o argumento matemático usado nas demonstrações em geral. Essas duas atividades são casos de validações aceitas pela comunidade da sala de aula. Em quaisquer dos casos, de explicação ou de prova, o aluno pode se apropriar de um resultado matemático. Mais adiante, nesta dissertação, analisamos uma sequência didática sobre esse tema, desenvolvida em uma classe de $6^{\circ}$ ano de Ensino Fundamental (no capítulo VI). Além disso, o caráter propício à generalização da validação proposta no segundo método favoreceu a evolução das concepções dos alunos sobre o conceito de validação, que é o de excluir contradições. Nesse caso constatamos que a construção do argumento que confirmou o mesmo resultado foi importante para a transposição de um pensamento ingênuo para um pensamento crítico.

Além da divisão entre provas pragmáticas e conceituais, Balacheff propõe ainda uma subdivisão das mesmas em quatro tipos (BALACHEFF, 1988): empirismo ingênuo, experimento crucial, exemplo genérico e experimento reflexivo. Os dois primeiros caracterizados como provas pragmáticas e os dois últimos como provas do tipo conceituais. Cada uma delas aponta para o desenvolvimento cognitivo do estudante sobre a necessidade de estabelecimento de provas.

O empirismo ingênuo consiste em associar a verdade de um resultado à verificação de vários casos particulares. O experimento crucial é um experimento projetado para permitir a comparação entre duas hipóteses ou conjecturas possibilitando a rejeição de alguma delas. O exemplo genérico assegura que se explicitem as razões da verdade de uma afirmação, por meio de operações ou transformações sobre um objeto particular (o exemplo em estudo) com estrutura e propriedades compatíveis com a classe de objetos que se deseja estudar. Finalmente, o experimento reflexivo supõe a internalização, o distanciamento de representações ou objetos particulares para a explicitação de propriedades gerais de uma classe de objetos. No capítulo $\mathrm{V}$, discutimos essa caracterização de provas fornecidas por Balacheff, sob a hipótese de auxiliar no aprendizado de Geometria. 
Balacheff salienta ainda que não é sempre evidente que os alunos percebam a necessidade de explicações ou provas, sejam do tipo que for. Podem convencer-se da validade sem sentir necessidade de explicitar as razões para tal. Por exemplo, na proposta de um jogo para a introdução de algum tema matemático, decisões deverão ser tomadas pelos alunos a partir do conhecimento das regras do jogo. Elas poderão ser individuais, sobre a determinação de uma estratégia para vencer (explicação para si próprio). Nesse caso, o indivíduo se convence por intuição sem perceber a necessidade de comprovar o fato - ganhar é suficiente para convencê-lo da validade de sua decisão. No caso de jogos cooperativos poderá ser necessária a exposição de argumentos para o convencimento de colegas sobre a validade de uma estratégia, podendo, no entanto, se restringir a uma prova pragmática. Mas o objetivo final da proposta de um jogo pelo professor é que, a partir das regras do jogo, sejam desvendadas as razões matemáticas que fazem certas estratégias serem vencedoras (construindo um sistema hipotético-dedutivo), ou seja, que se discutam provas conceituais em um contexto lúdico. Torna-se necessário que os estudantes realizem operações intelectuais sobre as regras do jogo para além dos controles lógicos e semânticos locais imaginados para ganhar o jogo. Porém, a necessidade de provas conceituais não ocorre naturalmente em uma situação de jogo, para a grande maioria dos estudantes. Vimos que a interação social pode impulsionar a consciência da necessidade de explicitar uma prova pragmática. Balacheff (1987) destaca a importância da ação do aluno sobre o objeto ou situação presente, para a evolução de suas concepções sobre o objetivo de uma prova conceitual. Para Paulo Freire (1996, p. 16), essa reorganização se dá na medida em que o educando é exposto a métodos mais rigorosos de pensamento, proporcionando a passagem de um pensamento ingênuo para o pensamento crítico. Esta reorganização de pensamento, caracterizada pela superação do pensamento ingênuo (e não sua ruptura, conforme diz Paulo Freire) deve ser valorizada em sala de aula de Matemática. Assim, cabe ao professor levantar questionamentos ou propor situações que desencadeiem nos alunos a necessidade desse tipo de ação, propiciando condições iniciais para se criar um espaço de argumentações justificadas. Segundo Balacheff, cabe ao professor questionar o aluno: Como ganhar sempre? Será que sua estratégia vale em qualquer situação do jogo (sendo o caso, exibindo uma situação em que a estratégia adotada não funcione, contrariando sua intuição)?

Balacheff (1987), incorrendo em certo abuso de linguagem relativamente à sua definição de prova, denomina as três situações descritas no parágrafo anterior, respectivamente por: provas para decidir (explicações auto convincentes na tomada de decisões individuais), provas para convencer (provas pragmáticas explicitadas a partir da 
necessidade de interação social); provas para conhecer (provas conceituais visando o conhecimento de propriedades matemáticas gerais). Nesse contexto, distinguem-se as provas pragmáticas das provas conceituais ou intelectuais. Uma situação de decisão, portanto, tornase uma situação de explicação ou prova conforme o rigor exigido na comunicação no interior do grupo social. A produção de provas obriga a utilização de um sistema de validação comum, ao menos localmente no grupo, com relação às proposições em debate.

Balacheff propõe ainda que, no contexto escolar, uma gênese cognitiva para que o educando entenda a necessidade de uma validação em Matemática: expô-lo a contradições fornecendo-lhe uma previsão e um dado externo que lhe transmita a negação de sua intuição. Para o autor, a identificação e a superação de contradições pode conduzir a uma reorganização do pensamento. E a tomada de consciência de tal contradição é determinante para a evolução das concepções de cada aluno (BALACHEFF, 1987). A seguir, temos um exemplo de experimento efetuado pelo autor que ilustra essa situação.

Em um experimento feito com alunos de quinto ano (correspondente ao $7^{\circ}$ ano do Ensino Fundamental no Brasil), em uma escola da França, a soma dos ângulos de um triângulo não foi considerada ser igual a $180^{\circ}$ para todos os triângulos. A partir da intuição um triângulo pequeno devem ter soma de ângulos menor do que um grande ${ }^{1}$,

Do ponto de vista didático, cabe ao professor oferecer condições para que a tomada de consciência da contradição aconteça, sendo esta tomada de consciência que produz uma reorganização do conhecimento. Essa concepção pode ser superada, em um primeiro momento, com algum experimento que transforme esse falso entendimento, como já comentado anteriormente, recortando os ângulos do triângulo e agrupando-os de modo a completarem o ângulo raso, como representado na figura 4.

O problema posto é oferecer uma contradição ao educando de maneira que ele escolha entre duas proposições: uma afirmação ou sua negação. Isso posto, dependendo de sua escolha, torna-se importante oferecer um contraexemplo que contradiga sua eventual escolha inadequada. A contradição é assim dependente de uma dupla construção e, dessa forma, destacam-se as condições seguintes como necessárias à tomada de consciência sobre o que está jogo em uma dada situação de validação (BALACHEFF, 1987): i) existência de uma

\footnotetext{
${ }^{1}$ Balacheff, N. 2004, pg. 149 "Pour des élèves de cinquième la somme des angles d'un triange ne peut être égale à 180 pour tout triangle, parce qu'un petit triangle ne peut avoir la même sommme d'angles d'un triangle plus grand." (Tradução do autor)
} 
expectativa sobre uma conjectura, ii) possibilidade de construir tanto a afirmação associada tanto à sua conjectura quanto a sua negação. Isto significa que a contradição está associada a um processo de análise, de forma explícita ou não, deliberada ou não, e também da decisão sobre a situação.

Quanto à utilização de argumentações, em particular as refutações, o objetivo é fazer com que o educando explore ativamente o espaço proposto para o desenvolvimento de atividades quanto aos aspectos de criação do conhecimento ou da análise de consequências de posições tomadas. Dito isso, conforme diz Balacheff, a experiência de expor os alunos a contradições fornece um desequilíbrio cognitivo e sua superação que resulta na possibilidade de novas construções pelo mesmo (BALACHEFF, 1987).

As atividades de Geometria são bastante interessantes para o desenvolvimento de experiências concretas que permitam ao aluno compreender a importância e a necessidade da prova para legitimar hipóteses e eliminar contradições em seu raciocínio. A seguir, discutimos, à luz da teoria de Van Hiele, como promover o desenvolvimento do pensamento geométrico.

\section{IV.3 Dina e Pierre Van Hiele: sobre o Desenvolvimento do Pensamento Geométrico}

O modelo para o desenvolvimento do pensamento geométrico proposto pelo casal Van Hiele indica que o aprendizado de Geometria, ou seja, a gradativa apropriação pelo estudante de vocabulário, conceitos e de propriedades geométricas, dá-se pela passagem por níveis sequenciais de pensamento. O modelo de Van Hiele pode ser usado tanto no ensino, quanto na avaliação da aprendizagem desse conteúdo. Ele indica motivos para os problemas de aprendizado em Geometria e oferece indícios de atividades a serem trabalhadas em sala de aula que favoreçam um real aprendizado pelos alunos (DE VILLIERS, 1999).

O aprendizado em Geometria refere-se ao desenvolvimento, pelo estudante, da capacidade de estabelecer relações entre os diversos elementos das figuras geométricas, reconhecer propriedades, fornecer definições etc. E, em nível mais abstrato, o aprendizado consiste na capacidade de sistematizar o pensamento geométrico por meio da utilização de sistemas axiomáticos diversos. Os autores propuseram um modelo composto por cinco níveis de compreensão (visualização, análise, dedução informal, dedução formal e rigor) para a descrição do processo de desenvolvimento do pensamento geométrico em que o aluno 
se move sequencialmente do nível mais básico (visualização) até o mais elevado (rigor), assim definidos (CROWLEY, 1994, pp. 2-4):

\section{Nível 0: Visualização}

Nesse nível, os alunos reconhecem as figuras geométricas por sua aparência global, sem identificar propriedades ou elementos. Por exemplo, ao ser apresentado um conjunto de quadriláteros compostos de quadrados e retângulos, um aluno nesse nível reconhece esses dois tipos por sua forma somente (Crowley, 1994, p. 3). O recurso visual é importante para reconhecer, comparar, classificar e descrever figuras, porém as descrições destes objetos são incompletas ou utilizam propriedades irrelevantes para classificá-las. Como exemplo, um indivíduo nesse nível de desenvolvimento de pensamento geométrico, é capaz de diferenciar, visualmente, quadrados de retângulos sem perceber que essas figuras têm lados opostos paralelos e quatro ângulos retos. É um estágio de criação de imagens mentais dos objetos geométricos constituindo-se em pré-requisito para a aquisição de linguagem específica da Geometria. Nesse estágio de desenvolvimento pode-se introduzir vocabulário para nomear figuras e realizar atividades de reconhecimento e reprodução informal de figuras.

Não se espera, portanto, argumentações nesse nível, nem mesmo explicações, nos termos de Balacheff.

\section{Nível 1: Análise}

Nesse estágio, por meio da prática da observação e experimentação, o reconhecimento de figuras passa a ocorrer pela identificação de seus elementos e de algumas de suas propriedades: o aprendiz começa a se apropriar de alguns conceitos geométricos simples. Para exemplificar, podemos citar o caso de classificação de figuras por meio de apenas uma propriedade, como a quantidade ou medidas dos lados (propriedades como simetrias, ângulos e diagonais, são ignoradas). Nesse nível a descrição das figuras é feita usando mais propriedades do que as suficientes para caracterizar uma dada figura geométrica. Dessa forma, pode-se dizer que os alunos caracterizam e observam as partes das figuras, podendo relacionar propriedades pertencentes a um mesmo tipo de figura.

Nesse nível, ainda, a identificação de propriedades em situações particulares é utilizada pelo aluno para estabelecer propriedades para toda uma classe de figuras. Por exemplo, a observação de que para um conjunto de paralelogramos os ângulos opostos têm mesma medida produz a intuição de que esse fato ocorre com todos os paralelogramos 
(CROWLEY, 1994, p. 3). As argumentações ocorrem por meio de exemplos, em e não com o uso de provas ou demonstrações.

Nos termos de Balacheff, o tipo de argumentação que convence o aluno nesse nível, baseado em exemplos, se constituem em provas pragmáticas.

\section{Nível 2: Dedução informal}

O uso espontâneo de definições e conceitos começa a ter importância e argumentos informais podem ser elaborados pelos aprendizes, embora as deduções nesse nível de desenvolvimento ocorram em torno de um tipo de figura. Conseguem fazer inter-relações entre propriedades em uma mesma figura (por exemplo, em um quadrilátero, se lados opostos são paralelos então ângulos opostos são congruentes). Pelo fato de conseguirem perceber a classificações hierárquicas como, por exemplo, nos quadriláteros, por meio do exame das propriedades, os alunos percebem que todo quadrado é um retângulo, pois um quadrado tem todas as propriedades que um retângulo possui. Nesse nível, os alunos possuem raciocínio dedutivo informal, mas ainda não são capazes de elaborar uma demonstração formal ou axiomática completa.

Nos termos de Balacheff, em nosso entendimento, os alunos que estão nesse nível são capazes de construir prova conceitual do tipo exemplo genérico.

\section{Nível 3: Dedução formal}

Alunos enquadrados nesse nível podem construir e entender diferentes tipos de demonstrações para um mesmo resultado. A importância do método dedutivo como um todo e o estabelecimento de uma teoria geométrica dentro de um sistema axiomático é entendida. Nesse contexto, os alunos são capazes de fazer distinção entre postulados, teoremas e definições, havendo, dessa forma, uma compreensão das respectivas funções dentro de uma estrutura axiomática da Matemática.

Neste nível os estudantes são capazes de fazer demonstrações, nos termos de Balacheff.

\section{Nível 4: Rigor}

Neste estágio, o aluno pode trabalhar em uma variedade de sistemas axiomáticos, incluindo as geometrias não euclidianas. Além disto, compreende a importância da precisão 
ao tratar ideias e relações matemáticas. As demonstrações nesse nível demandam um grau de formalismo e de rigor bem próximo ao das deduções do matemático profissional.

Um aspecto importante a se destacar sobre o modelo Van Hiele é que, nos diferentes assuntos abordados em Geometria, o processo de ensino deve recomeçar do nível de visualização, fazendo com que o aluno progrida sequencialmente entre os níveis do modelo até aquele adequado à sua fase de escolaridade. A cada assunto ou tópico da Geometria, símbolos e linguagem próprios precisam ser assimilados, bem como relações e propriedades pertinentes à nova situação que se configura. Particularmente, no que diz respeito às deduções em Geometria, há a necessidade de fazer com que o aprendiz, por meio da investigação e experimentação, evolua de uma situação, em que o espaço é simplesmente visualizado e as propriedades das figuras não são reconhecidas explicitamente, até ser capaz de produzir deduções, com compreensão. Esse fato deve ser considerado pelo professor em uma sala de aula.

Outro aspecto importante dessa teoria é que, segundo o casal Van Hiele, a progressão de um nível para outro depende muito mais das metodologias empregadas e da organização das aulas do que da idade dos estudantes. Assim, complementando a ideia de progresso de aprendizado nos níveis, propuseram cinco fases sequenciais de aprendizagem a serem percorridas igualmente em cada nível, para orientar o planejamento de aulas e a escolha de metodologias de ensino de Geometria: interrogação, orientação dirigida, explicação, orientação livre e integração (CROWLEY, 1994, p. 5).

\section{Fase 1: Interrogação}

Nessa fase, os objetivos são fazer:

a) um diagnóstico dos conhecimentos prévios dos alunos no que diz respeito à linguagem pertinente ao tema ou assunto em questão, conceitos, ideias, etc.;

b) possibilitar que os alunos tomem conhecimento da direção que tomarão seus estudos.Por exemplo, visando verificar os conhecimentos de estudantes de um sexto ano do Ensino Fundamental sobre comparação de ângulos, para posteriormente compreendam a classificação de triângulos, o professor pode entregar aos alunos desenhos de triângulos de vários tipos e perguntar e fazer perguntas do tipo: algum dos ângulos é maior que os outros? Por quê? 


\section{Fase 2: Orientação dirigida}

Para o casal Van Hiele, a sequência das atividades propostas pelo professor é importante para o progresso do aprendizado do aluno em cada um dos níveis descritos anteriormente. $\mathrm{Na}$ exploração dos tópicos, as tarefas pelas quais os alunos passam precisam incluir vivências de propriedades e características pertinentes ao nível em questão - quer na apropriação de linguagem e relações, quer na apropriação de conceitos mais gerais.

Na sequência do exemplo anterior, pode-se solicitar que recortem os triângulos e que façam a comparação por meio de dobraduras.

\section{Fase 3: Explicação}

Os alunos começam a explicitar seu entendimento sobre as novas relações por eles observadas, fazendo uso de linguagem precisa e adequada ao contexto em estudo.

Exemplificando essa situação, ao comparar os ângulos os alunos percebem que possuem medidas variáveis. Dessa forma, uma linguagem pode ser introduzida para que expressem essa comparação entre os ângulos de forma a possibilitar que expressem suas ideias por escrito e oralmente.

\section{Fase 4: Orientação livre}

Nessa fase, é apresentada aos alunos uma tarefa mais complexa em que eles são convidados a resolverem problemas utilizando os recursos que aprenderam de forma autônoma.

Continuando a situação exemplificada na fase 3, pode-se pedir que os alunos estabeleçam relações entre as medidas dos ângulos e as medidas dos lados. Nesse momento, é interessante estabelecer também uma classificação para os triângulos segundo o número de ângulos ou lados de mesma medida. Pode-se perguntar se as duas classificações (pelos ângulos e pelos lados) são distintas.

\section{Fase 5: Integração}

Consiste na fase em que, com a ajuda do professor, os alunos revisam e sistematizam o que aprenderam durante a tarefa. 
Nessa fase, em uma discussão coletiva, podem-se resumir as conclusões obtidas que, no caso do nosso exemplo, são as relações presentes nos triângulos entre ângulos e seus lados opostos, bem como a classificação dos mesmos em equiláteros, isósceles e escalenos.

A seguir, visando discutir como se dá um trabalho com argumentações e provas no ensino de Geometria na Educação Básica, fazemos uma discussão mais aprofundada sobre abordagens desses temas em sala de aula, tendo por base as teorias de Balacheff e Van Hiele já discutidas aqui. Destacamos que a relação entre os dois trabalhos é pertinente, pois a passagem pelos níveis de Van Hiele, amparados pela análise de provas pragmáticas e conceituais de Balacheff, conduzem a um dinamismo capaz de contribuir para a passagem do aluno de um nível ao outro. 


\section{Capítulo V - A Construção de Provas Geométricas à Luz dos Trabalhos de Balacheff e Van Hiele}

O elemento norteador para a construção deste capítulo é a hipótese de que propiciar aos alunos vivências com provas pragmáticas e conceituais em Geometria facilita a transição de seu aprendizado pelos níveis de Van Hiele. A criação de um ambiente (cenário para investigação) onde há a possibilidade de se fazer uso desses tipos de provas, amparado fortemente pelo recurso de argumentações e refutações, em nossa opinião, pode constituirse em uma metodologia de ensino de Geometria que favoreça o desenvolvimento do pensamento geométrico desde o nível de visualização até níveis mais avançados do modelo Van Hiele. Segundo Balacheff, a abordagem de argumentações e refutações em sala de aula de Matemática pode fazer com que alunos e professores participem ativamente da construção do conhecimento e, além disso, a observação da linguagem empregada para a exposição de validações pode ser utilizada para diagnóstico do nível de Van Hiele em que o aluno se encontra.

Van Hiele e Balacheff, em suas propostas, destacam que os alunos transitam por níveis elementares de pensamento até o nível de produção de raciocínios complexos e mais gerais. Ambos preveem, dessa forma, a evolução das concepções dos alunos com o objetivo de alcançar maior rigor no tratamento das situações. Assim, pode-se estabelecer uma correlação entre a transição do nível visualização em direção às deduções, proposta pelo primeiro autor com a transição das provas pragmáticas para as conceituais, do segundo. É por esse motivo que a produção de provas em sala de aula, alicerçada nos trabalhos desses autores, pode contribuir para o desenvolvimento nos estudantes do importante aspecto do pensar certo definido por Paulo Freire (1996, p. 16), um raciocínio global sobre a situação.

A produção de provas pelos alunos é um assunto tratado de forma específica por Balacheff em seu artigo "Aspects of proof in pupil's practice of school Mathematics" (BALACHEFF, 1988). Nesse experimento, a produção de provas geométricas pelos alunos, caracterizadas como provas pragmáticas e conceituais, é estudada por meio da análise da linguagem por eles utilizada para expressarem seus resultados. Foram utilizadas pelo autor para verificar o quão os alunos apreciavam o caráter genérico da situação, expondo soluções ou provas de caráter mais geral. Para isso, a linguagem por eles utilizada foi determinante na avaliação da situação.

Nesse contexto por ele analisado, a forma mais elementar de expressão de uma prova é a exibição de figuras ou esquemas que não explicitam operações e conceitos utilizados 
pelo aluno, embora quem exiba faça algum uso mentalmente. A utilização de diagramas, esquemas, etc., que apoiam a exposição desses tipos de provas como esboço daquilo que o locutor tem em mente e não consegue explicar de outra forma, não caracteriza uma total ausência de linguagem. Mas tais procedimentos não chegam a ser meios de transmitir conhecimento, o que é uma função de uma validação matemática. O movimento em direção às provas conceituais requer uma alteração de posição no que se refere à utilização dessa linguagem. A linguagem do dia a dia, suportada pela linguagem natural, permite algum movimento na direção da apreciação do caráter geral de uma situação; mas aqui deve ser mais do que isso para produzir provas formais. Linguagem essa que deve tornar-se uma ferramenta para deduções lógicas e não exatamente um meio de comunicação em seu nível mais elaborado e preciso.

Entre as provas pragmáticas e conceituais definidas por Balacheff $(1987,1988)$, destacamos os quatro tipos: empirismo ingênuo, experimento crucial, exemplo genérico e experimento reflexivo. Os dois primeiros tipos não estabelecem a verdade de uma asserção, mas chamamos de prova porque eles são reconhecidos como tal por seus produtores. Os dois últimos, exemplo genérico e experimento crucial, estabelecem a necessária natureza de sua verdade por meio de motivos ou fundamentos expressados. Além disso, o autor afirma que essas formas de provas constituem uma hierarquia em que cada um desses tipos de validações são situados nessa ordem conforme o grau de generalidade que a mesma demanda. Assim, passar de uma situação de exemplo genérico para um experimento reflexivo, por exemplo, exige passar da ação para a ação internalizada, ou seja, da ação sobre o objeto para utilização de uma linguagem mais geral para a exposição do argumento.

Em linhas gerais, segundo esse autor, a linguagem utilizada pelo aprendiz para expressar uma prova é determinante para expressar o entendimento que o aprendiz possui sobre o caráter geral da situação. Portanto, é a transição, das provas pragmáticas (que fazem uso do recurso de uma figura ou qualquer linguagem não formal para serem explicitadas verificações experimentais) para as provas conceituais (que envolvem a utilização de linguagens mais gerais que as expressas nas provas pragmáticas) que produz uma evolução da concepção dos alunos em direção à apropriação do caráter geral da situação.

Em uma reflexão sobre a natureza da validação do conhecimento matemático, reconhece-se que qualquer verificação experimental ou medição feita em objetos físicos, é útil para compreender padrões para uma posterior exibição de demonstração formal ou dedução matemáticas sobre o caso geral (BRASIL, 2000, pp. 26, 127). O ensino de Matemática exercido em ambientes de investigação, como proposto por Skovsmose, ou 
integrado e relacionado a outras áreas do conhecimento proporciona "o desenvolvimento de competências e habilidades que são essencialmente formadoras, à medida que instrumentalizam e estruturam o pensamento do aluno" (BRASIL, 2000, p. 111). Nesse sentido, a produção de validações pelo aluno que promova desenvolvimento de raciocínio ou pensamento, no sentido proposto por Balacheff e Van Hiele, torna relevante o aprendizado dessa ciência como contribuição para a formação integral do educando. Esse é um dos fatores, portanto, "que assegura um papel de relevo ao aprendizado dessa ciência em todos os níveis de ensino" (BRASIL, 2000, p. 26).

A linguagem que o aluno usa para explicitar provas é fundamental para estabelecer a distinção entre os tipos de provas pragmáticas (empirismo ingênuo e experimento crucial) e conceituais (exemplo genérico e experimento reflexivo). No empirismo ingênuo e no experimento crucial o aluno baseia-se em fatos concretos para explicitar o resultado e suas ações ocorrem sobre o objeto e, nos dois últimos (exemplo genérico e experimento reflexivo), o mesmo faz uso de linguagens que expressam um caráter mais geral para a solução. No que se refere à transição entre esses tipos de prova, aponta Balacheff(1987) que na distinção entre os pares (empirismo ingênuo - experimento crucial), por um lado, e (exemplo genérico - experimento reflexivo), por outro, observa-se uma lacuna. Segundo o mesmo, não é necessariamente claro, do ponto de vista das atividades presentes na sala de aula, como se dão as passagens das provas que compõem o primeiro para a do segundo par. Outra questão a ser avaliada ocorre no interior dos próprios pares, pois o tipo de prova pragmática que foi produzida só é identificável ao término da explicitação da prova pelo aluno.

A problemática de transitar pelos níveis de Van Hiele também possui obstáculos. Por exemplo, as relações presentes no nível 0 diferem substancialmente das relações e conteúdos geométricos que o aprendiz deve se apropriar a fim de que possa ser enquadrado no nível 1. As redes de relações diferem também entre os níveis 1 e 2. Enquanto a rede de relações no nível 1 envolve a associação de propriedades comuns em diversos tipos particulares de figuras, a rede de relações no nível 2 envolve as relações lógicas entre as propriedades das figuras. A rede de relações no nível 2 não mais se refere a figuras concretas e específicas, e tampouco tais relações formam uma estrutura de referência na qual se sabe a pergunta sobre se uma certa figura possui determinadas propriedades. Por fim, os conhecimentos geométricos que contribuem para o indivíduo raciocinar respeitando um sistema lógico dedutivo pertencem ao terceiro nível de pensamento. Todos os níveis têm suas próprias redes de relações, uma sendo diferente da outra. A rede de relações do primeiro nível de 
pensamento, que se baseia em uma descrição verbal de fatos observados, tem como prérequisito a apropriação das relações presentes no nível zero, em virtude da propriedade sequencial. De Villiers (1999), por exemplo, afirma que para os alunos começarem a explorar as relações lógicas entre propriedades geométricas no nível 2 é necessário que as redes de relações do nível 1 estejam estabelecidas. Nesse caso, uma reorganização de pensamento se faz necessária, pois no nível 2 as redes de relações são completamente diferentes daqueles presentes no nível 1. Contudo, a questão que se segue é: como fazer com que o aprendiz siga sequencialmente por esses níveis? Ou seja, do ponto de vista das atividades que podem ser propostas em sala de aula de Matemática, como fazer com que o aluno reorganize seu pensamento a fim de que o mesmo transite pelos níveis de pensamento geométrico que propôs o casal Van Hiele?

A partir de um problema exposto por Balacheff (1988), em que um grupo de alunos devia determinar uma lei geral que fornecesse o número de diagonais de um polígono convexo e construir um argumento para justificar a generalidade do resultado obtido, faremos a seguir uma discussão sobre como promover uma evolução do educando no trânsito pelas provas pragmáticas em direção às provas conceituais geométricas. Para tanto, faremos uso da exposição do aluno a contradições em suas convicções para provocar esse movimento.

Uma contradição existe somente relativamente a um sistema cognitivo. Por exemplo, em sala de aula uma contradição pode ser reconhecida pelo professor, mas não pelos alunos. Assim, conforme já apresentamos anteriormente, a soma dos ângulos internos de um triângulo, na concepção dos estudantes, pode variar conforme as dimensões do respectivo triângulo (BALACHEFF, 1988). Portanto, o reconhecimento por parte do aluno de tal contradição demanda a intervenção do professor para que o educando tome consciência da mesma, de maneira a ser capaz de escolher entre duas proposições (uma afirmação ou a negação). Em nosso entender, essa é a condição para o estabelecimento da reorganização do conhecimento a ser adquirido. Assim, as condições necessárias para a emergência da conscientização de uma contradição são: (i) a existência de uma expectativa ou uma antecipação; (ii) a possibilidade de construir e formular um argumento relacionado a esta expectativa; e (iii) a possibilidade construir sua negação. A existência de uma expectativa significa que o sujeito está comprometido com uma asserção e é hábil a considerá-la como objeto de pensamento ou um objeto de discurso. O tratamento de refutações é o cerne para a busca de utilização de contraexemplos para a exposição de contradições. 
Primeiramente, explicitamos uma situação de empirismo ingênuo. A partir do estudo de polígonos particulares como o quadrado, o hexágono e o octógono, alunos conjecturaram que o número de diagonais é igual à metade do número de lados.
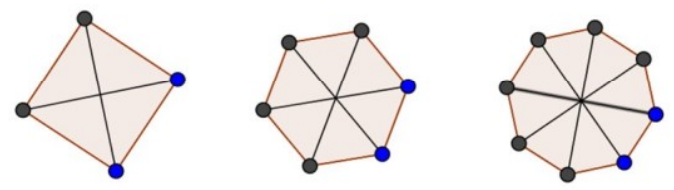

Figura 5 Determinação do número de diagonais dos polígonos

Uma análise inicial mostrou que o entendimento do conceito de diagonal que os alunos possuíam, induziu-os a excluírem os segmentos que não passam pelo centro do polígono. Agravando a situação, observa-se que recorreram a polígonos regulares com um número par de lados para explicarem seus resultados. Assim, para fins de um melhor entendimento do conceito e, consequentemente, a refutação do resultado obtido, o professor pode fazer uma intervenção junto a esses alunos solicitando que construam então polígonos não regulares com quantidade par e ímpar de lados. Dessa forma, a partir da construção de um pentágono (ver figura 4) para a verificação do resultado, consegue-se que - seja qual for a contagem que indique o número de diagonais desse polígono $(0,1,2,3,4$ ou 5$)$ - seu resultado não valide a conjectura por eles formuladas. Esse caso de empirismo ingênuo, portanto, pode ser utilizado para colaborar para a evolução da necessidade de identificar eventuais distorções em seu conceito de diagonal, bem como refutar seu resultado e introduzir os alunos ao nível do experimento crucial, que discutimos a seguir.

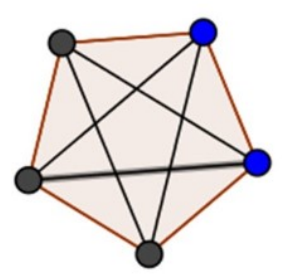

Figura 6 Número de diagonais de um pentágono

Estabelecer uma conjectura sobre o número de diagonais envolve, num primeiro momento, a experimentação e observação de vários polígonos com o objetivo de se formular um padrão que abarque o resultado prévio conjecturado. O experimento crucial, nesse caso, consiste em os próprios alunos, que estabeleceram a conjectura, confirmarem o resultado por meio de um exemplo diferente daqueles já utilizados. Além disso, é importante observar que 
confirmação de um resultado por meio de exemplos pode ser entendida como um caso de experimento crucial, desde que os próprios alunos exponham algum outro exemplo que valide, ou não, sua conjectura. No caso da hipótese feita pelos alunos de que o número de diagonais é sempre metade do número de lados, os próprios indivíduos poderiam ter a iniciativa de validarem o resultado por meio da utilização do polígono de 5 lados. Assim, teriam construído um contraexemplo para sua conjectura e, a partir dessa constatação, perceberiam que outra construção que dê conta dos polígonos com quantidade ímpar de lados deve ser feita.

Analisando as situações descritas (de empirismo ingênuo e experimento crucial), observa-se que redes de relações são feitas pelos alunos, tanto para construir, quanto para tentar confirmar seus resultados e uma observação que deve ser feita refere-se à busca por uma resposta mais geral. No primeiro caso a resposta, oferecida pelos alunos que utilizaram uma prova do tipo empirismo ingênuo, mostra que eles se satisfizeram com uma examinar figuras bem particulares (polígonos regulares com quantidade par de lados). No segundo caso, é nítido que os aprendizes tiveram uma percepção mais geral da situação. $O$ experimento crucial poderia validar o resultado, mas deve ficar claro que o caráter de generalidade desse tipo de prova inexiste. Por outro lado, podemos observar que a interação social, seja professor-aluno ou aluno, conforme diz Balacheff (1987), é o motor para apropriação pelo educando sobre o caráter geral da situação.

A partir de uma análise prévia dos níveis de Van Hiele, podemos dizer que o aprendiz capaz de explicitar uma prova pragmática situa-se, ao menos, no nível 1 de análise. O nível precedente (visualização), conforme já destacamos, é um estágio de criação de imagens mentais dos objetos geométricos que antecede a aquisição de linguagem específica em Geometria, não cabendo, portanto, propor atividades que envolvam argumentações, nos termos de Balacheff. Já no nível 1, as explicitações de provas ocorrem por meio da utilização de exemplos e, por meio da observação e experimentação, o educando constrói ou apropriase da linguagem técnica para descrever propriedades e conceitos. Para exemplificar essa situação, na proposta de atividade que aqui descrevemos, num primeiro momento, dá-se um exercício de visualização de figuras e contagem de diagonais, situando-se, portanto, no nível 0 . A seguir passa-se à etapa em que o aluno é convidado a relacionar a propriedade geral que estabelece o número de diagonais de qualquer polígono, situando-a, portanto, no nível 1. Nesse sentido, corroborando essa necessidade de apropriação pelo aprendiz de habilidades mais gerais que o habilitem a explicitar uma prova, essa evolução do nível 0 para o nível 1 envolve o reconhecimento de algumas novas relações entre conceitos e a aquisição de 
linguagem. Ou seja, a transição do nível 0 para o nível 1 ocorre em meio a uma reorganização de pensamento geométrico no que se refere à aquisição de linguagem que permita a expressão de relações e refinamento de conceitos pelo aprendiz e ao mesmo tempo atuar sobre o objeto em estudo. Nessa atividade, portanto, a transição do empirismo ingênuo para o experimento crucial pode contribuir para que o aluno transcenda o nível 0 em direção ao nível 1.

A transição do nível 1 para os níveis 2 e 3 de Van Hiele põe em relevo a necessidade de apropriação, pelo aprendiz, de outros conhecimentos além do geométrico. Há a necessidade da utilização de uma linguagem que explicite de forma mais geral as convicções que o educando possui e, ao mesmo tempo, substitua a validação baseada apenas em figuras. A partir disso, propomos que o aprendizado de modelagem algébrica e de formas de representações mais gerais que permitam explicitar resultados na forma de um encadeamento dedutivo, são os conhecimentos que ajudam a promover a transição do nível 1 para o nível 2, e do nível 2 para o nível 3, respectivamente. Esse fato é claramente observável naqueles alunos que utilizaram a prova pragmática do tipo exemplo genérico (no nível 2 de Van Hiele) e provas conceituais (no nível 3).

Dessa forma, a apreciação do caráter geral da situação de estabelecimento de uma prova que valide a afirmação do aluno sobre o número de diagonais de um polígono está condicionada à linguagem utilizada. Van Hiele nos fornece o caminho a seguir no sentido de buscar o desenvolvimento do pensamento geométrico como um todo no educando, e não só obter provas e chegar ao formalismo matemático. Já Balacheff fornece os meios de, progressivamente, nível a nível, por meio da elaboração de provas pragmáticas e conceituais, apreciar o caráter geral de uma prova e, simultaneamente, desenvolver seu pensamento geométrico.

No experimento detalhado por Balacheff (1988) para a construção de uma prova do tipo exemplo genérico, foi necessária uma linguagem mais abrangente do que a simples utilização de figuras para justificar as afirmações. Nesse contexto, os aprendizes que explicitaram uma prova desse tipo buscaram uma relação que transpusesse a mera utilização de exemplos, apresentando uma resposta mais geral do que as fornecidas por aqueles que explicitaram provas dos tipos empirismo ingênuo. E, em se tratando de Geometria, a representação genérica do número de diagonais de um polígono envolve a utilização da álgebra como recurso. 
Nessa atividade, um modelo que expressa o número de diagonais foi dado pela fórmula, onde n é a quantidade de lados do polígono e d o número de diagonais:

$$
\mathrm{D}=\frac{n(n-3)}{2}
$$

Como validação matemática, ao compararmos os três tipos de provas anteriormente descritos, o exemplo genérico possui caráter mais geral. Apesar disso, desde a construção do modelo, baseada em observação de alguns casos particulares, sua validação está condicionada a testes de vários exemplos para a comprovação de sua generalidade, ou, da mesma forma, obter-se algum que o invalide. Em qualquer caso, somente explicitar o modelo algébrico não constitui uma demonstração, pois este será sempre alvo de questionamentos sobre sua validade em geral. Assim, em nosso entendimento, a utilização de uma linguagem algébrica é necessária, mas não suficiente para se obter uma validação geral para expressar o resultado; por outro lado, pode constituir-se em uma situação de transição do aluno para a busca de uma prova do tipo experimento reflexivo.

Como alternativa à prova do tipo exemplo genérico, o experimento reflexivo é um tipo de dedução informal na qual, apoiado em testes empíricos com figuras para a observação de padrões, o aprendiz apresenta justificativas baseadas nas propriedades e relações observadas nos objetos em questão. Balacheff classifica esse tipo de prova como conceitual. Nas palavras do autor, na explicitação desse tipo de prova, as propriedades são formuladas em sua generalidade e há uma desvinculação dos exemplos particulares utilizados, ou seja, a ação sobre o objeto é transformada em construções linguísticas para explicitar as regularidades do mesmo, a fim de formular uma argumentação sobre a validade do resultado expresso em termos algébricos. Na proposta de atividade sobre diagonais de polígonos, aqui descrita, uma prova do tipo experimente reflexivo é descrita a seguir (BALACHEFF, 1988).

Em qualquer polígono, de cada vértice partem n-3 diagonais, pois não existe uma diagonal que una um vértice com si próprio nem com os dois adjacentes. Além disso, como são $n$ vértices, $n(n-3)$ diagonais devem ser consideradas. Por outro lado, observando que cada diagonal é contada duas vezes, temos que seu número total deve ser dividido por dois. Logo, o total de diagonais de qualquer polígono é:

$$
\mathrm{D}=\frac{n(n-3)}{2}
$$


Comparando esses dois últimos tipos de prova (exemplo genérico e experimento crucial), o primeiro constitui um estágio de transição entre as provas pragmáticas e o experimento reflexivo ou prova conceitual. Apesar do primeiro tipo sempre requerer uma negociação entre os interlocutores sobre o caráter geral do modelo empregado, o aprendiz que explicita uma prova do tipo exemplo genérico está potencialmente apto a construir provas do tipo experimento reflexivo, que requerem o abandono da linguagem apenas apoiada em exemplos, em favor de outra de caráter geral, que dispense a ação sobre o objeto para fins de validação da afirmação. Ou seja, para a transição desse primeiro tipo ao segundo, há a necessidade de uma reestruturação cognitiva pelo indivíduo que possibilite uma construção linguística para enunciar a prova.

Conforme dissemos anteriormente, o objetivo é promover a transição do aluno entre os níveis de Van Hiele. Dessa maneira, o argumento informal construído, do tipo experimento reflexivo, situa o aprendiz no nível 2 de Van Hiele e, potencialmente, o habilita a utilizar verdades lógicas ou geométricas para fazer deduções a partir das mesmas, favorecendo a apropriação de habilidades pertinentes ao nível 3. Analisando seu argumento, podemos supor que o aluno tenha encadeado mentalmente seu raciocínio da seguinte forma: 1) De cada vértice, partem $n-3$ diagonais.

2) Assim, se um polígono tem n vértices, então existem n(n-3) diagonais num polígono.

3) Ora, como cada diagonal é contada duas vezes, temos que o número n(n-3) está duplicado.

4) Portanto, a quantidade de diagonais de um polígono é $\mathrm{D}=\frac{n(n-3)}{2}$

A compreensão sobre a necessidade e vantagens de se utilizar uma linguagem mais abstrata e, de certa forma, mais precisa para estabelecer a validade da conjectura, não garante a compreensão automática do método dedutivo ou do método axiomático, habilidades próprias de um aprendiz que esteja no nível 3 (onde a demonstração exige o uso do princípio da indução finita). A formulação de provas pragmáticas e conceituais - que discutimos no parágrafo anterior - garante, ao menos potencialmente, que os alunos fiquem preparado para se apropriar das relações e propriedades geométricas pertinentes ao nível posterior. Dito isso, pelo fato das provas por eles construídas estarem baseadas em um tipo de figura e em argumentos informais, as situamos no nível 2. Ainda assim, em virtude do raciocínio hipotético-dedutivo que os alunos tenham feito, pelo menos mentalmente, para explicitarem seus argumentos, isso indica que a transição para o nível 3 esteja favorecida. 
Para Balacheff, esse desenvolvimento é fruto de uma mudança efetiva na forma de pensar sobre o problema que pode residir em um desejo de livrar-se de incertezas e contradições em seu raciocínio. Em resumo, para a produção de provas conceituais é necessário que o educando abandone a necessidade de atuar sobre os objetos (exemplos figurais) para provar e atue sobre toda a classe de objetos (descontextualização). O abandono da ação sobre os objetos requer que o aprendiz transponha as operações sobre os dados, e esse processo é fundamental para a passagem do universo das ações para o das relações e operações (atemporalização). Além disso, na atividade matemática profissional, com frequência, os teoremas são descobertos por meio da intuição e de métodos indutivos, antes de serem validados, mesmo quando resultados novos também tenham sido descobertos por processos puramente dedutivos como as Geometrias não Euclidianas (despersonalização) (BALACHEFF, 1987). Assim, a convicção pessoal do matemático sobre a validade de um resultado depende habitualmente de uma combinação de intuição, verificação quaseempírica e da concordância com uma demonstração lógica (não necessariamente rigorosa).

A interação social também concorre para a mudança de pensamento do educando, pois o rigor e precisão na argumentação dependem do grupo social a que se destina a comunicação do resultado (BALACHEFF, 1988). Em situação correlata, a consolidação do indivíduo em um determinado nível de Van Hiele ocorre quando ele é capaz de explicitar suas ideias claramente no interior do mesmo. Por exemplo, no que se refere à apropriação pelo educando do terceiro nível de Van Hiele, De Villiers (2010) afirma que “[...] a segunda rede de relações está presente de forma adequada tal que sua estrutura se torna aparente e alguém pode falar sobre ela com outras pessoas, é então que os elementos constituintes do Nivel 3 estarão prontos".

Portanto, a necessidade de comunicar, que por si só, implica a interpretação mútua de sistemas cognitivos, requer a passagem de uma linguagem familiar para uma linguagem funcional, que atenda aos diversos grupos sociais a que se destina a comunicação (BALACHEFF, 1987). Caracterizada pela introdução de simbolismo como aquela utilizada nas provas pragmáticas e conceituais, a utilização de um sistema de validação comum garante que, ao menos localmente, com relação às proposições em debate, todas as partes interlocutoras fiquem convencidas do caráter de verdade da prova que é explicitada (despersonalização).

Diante do exposto, concluímos que a passagem pelas provas pragmáticas e conceituais geométricas, conforme detalhamos neste trabalho, favorece a transição do 
educando dos níveis 0 ao 2 de Van Hiele e que somente a partir de uma reconstrução cognitiva, a transição pode se dar de fato.

A relação existente entre os trabalhos de Balacheff e Van Hiele, ambos objetivam a aprendizagem de Matemática, não como um aglomerado de conhecimentos, mas sim como um aprendizado que favoreça a evolução das concepções do aluno no que se refere ao entendimento global da situação. Para ambos os autores, a produção de provas mais gerais, ou o desenvolvimento pelo educando da capacidade de demonstrar, é o ápice desse tipo de pensamento.

O raciocínio formal ou o nível dedutivo formal é um ideal a ser atingido. Van Hiele, ao propor os níveis de aprendizado geométrico, mostra que os aprendizados de tópicos de Geometria seguem níveis sequenciais. Balacheff(1988), por exemplo, ao classificar os tipos de provas pragmáticas, mostra a possibilidade de fornecer tarefas de maneira que o aluno possa evoluir em suas concepções, passando da produção de provas do tipo empirismo ingênuo ao entendimento e produção de provas do tipo conceitual. Balacheff (1987) mostra ainda que um trabalho com argumentações e refutações em sala de aula é fundamental para que haja essa evolução. Como exemplo, discutimos no capítulo VI como uma atividade de produção de provas pragmáticas auxilia o aluno na transição dos níveis de Van Hiele. Portanto, essa evolução das concepções do aluno pode conduzir ao aprendizado, ou, nos termos de Paulo Freire, concorre para o desenvolvimento do pensar certo.

A prática de provas requer raciocínio e um estado específico de conhecimento, sendo, portanto, a qualidade das experiências matemáticas propostas aos estudantes da Educação Básica que determinarão sua evolução na produção. Experiências e metodologias essas que precisam auxiliar o estudante a adquirir autonomia na busca para a solução de problemas privilegiando a investigação e não a prática de exercícios repetitivos (SKOVSMOSE, 2000). No capítulo a seguir, descrevemos um experimento didático realizado com uma turma de $6^{\circ}$ Ano do Ensino Fundamental, à luz do referencial teórico aqui exposto, com o objetivo de favorecer a construção de provas e o desenvolvimento de argumentações e de senso crítico. 


\section{Capítulo VI - Sequência Didática em Geometria desenvolvida em uma turma de $6^{\circ}$ ano do Ensino Fundamental: Soma dos Ângulos Internos de um Triângulo}

O principal objetivo da sequência didática desenvolvida foi criar um espaço de argumentações e refutações no sentido de Balacheff (1987). O objetivo específico da experiência realizada foi o de desenvolver uma sequência de atividades que levasse os alunos de $6^{\circ}$ ano a demonstrar o seguinte resultado da Geometria: a soma dos ângulos internos de qualquer triângulo é $180^{\circ}$; e, a seguir, conjecturar (e provar) sobre qual é o valor da soma dos ângulos internos de um polígono qualquer. Para isso, buscamos propiciar aos alunos a possibilidade de construir esses conhecimentos.

Nessa atividade, pertinente ao contexto puramente matemático, sua construção e desenvolvimento está embasada na matriz proposta por Skovsmose sobre os ambientes de investigação possíveis de serem trilhados no que se refere ao ensino de Matemática. Buscamos favorecer a investigação e a descoberta, permitindo que no decorrer da tarefa o aluno modifique e reordene ideias e corrija erros, desenvolvendo a capacidade de pensar por si mesmo, levando os estudantes a agirem em seus processos de aprendizagem, formando um sujeito crítico, em contrapartida ao ensino tradicional de Geometria, pautado por meio da apresentação de modelos prontos que não proporcionam ao aluno momentos para manipulações, questionamentos ou estabelecimento de hipóteses, que o levem a construir o conhecimento e tornar significativos os resultados.

A construção do resultado visado foi mediada por questionamentos, argumentações e refutações. Propusemos comandos (tarefas e desafios) aos alunos sobre como relacionar ângulos ou determinar a altura de um triângulo, sem instruções prévias de como fazê-lo. Assim os jovens tiveram que encontrar uma forma de executá-los podendo discutir entre si. O papel do professor durante esse trabalho foi somente de guia, propondo contraexemplos ou estabelecendo linguagem comum para a comunicação dos resultados.

No que segue, descrevemos somente o que ocorreu em sala durante as atividades, como as impressões ou afirmações dos alunos e os recursos que utilizei para refutá-los. As medições ou outros valores numéricos são apenas para ilustrar a situação. 


\section{VI.I A Sequência Didática e sua Aplicação em Sala de Aula}

Tivemos como meta global nesse experimento trabalhar com construções geométricas para analisar como podem favorecer que os alunos desenvolvam as habilidades de visualizar, elaborar conjecturas e fazer demonstrações.

Elaboramos o seguinte plano de aula para a sequência didática que norteou a aplicação das atividades.

\section{Objetivo geral da sequência didática}

Propiciar aos alunos que vivenciem uma experiência concreta de inferência lógica e que desenvolvam habilidades de argumentação e senso crítico.

\section{Objetivos específicos da sequência didática}

Assegurar a apropriação pelos alunos (revisar ou ensinar) de uma linguagem comum sobre classificações básicas de ângulos e triângulos; determinar a soma dos ângulos internos de um triângulo e verificar a possibilidade dos alunos conseguirem utilizar esse resultado para determinar a soma dos ângulos internos para qualquer polígono convexo.

\section{$\underline{\text { Metodologia }}$}

Trabalho em grupos a partir de algumas questões propostas, para que os alunos, utilizando régua, transferidor e dobraduras, identificassem características, elementos e propriedades dos triângulos.

Aulas dialogadas garantindo amplo espaço para a exposição das ideias propostas pelos alunos.

\section{$\underline{\text { Material }}$}

Papel, lápis, régua, transferidor e tesoura.

\section{Organização}

Os alunos trabalharam em grupos de 4 ou 5 integrantes, com debates nos grupos individualmente e, posteriormente, um debate conjunto com o grupo da sala de aula e conduzido pelo professor. 
Número de aulas previstos: 10 aulas.

A descrição da aplicação do experimento foi baseada em registros das observações do professor ao longo das aulas. Não nos foi viável gravar as aulas seja em áudio ou em vídeo. Segue o relato dos trabalhos desenvolvidos efetivamente em sala de aula.

\section{$\underline{\text { Desenvolvimento das Atividades Didáticas }}$}

Etapa 1: Comparação das medidas de lados em um mesmo triângulo

Essa etapa foi desenvolvida em uma aula. Inicialmente, cada grupo recebeu três folhas distintas com desenhos de três triângulos de formatos diferentes: equilátero, escaleno e isósceles. Foram distribuídos 30 triângulos distintos na sala. Foi solicitado como primeira tarefa que, para cada triângulo, usassem a régua para registrar as medidas dos lados. $\mathrm{O}$ objetivo foi que os grupos identificassem as características dos triângulos quanto às medidas de seus lados.

Todos os grupos perceberam que na sua folha havia um triângulo com três lados de mesma medida; um triângulo com dois lados de mesma medida e um triângulo com os três lados de medidas diferentes e passaram à segunda etapa.

Etapa 2: Comparação das medidas dos ângulos internos de cada triângulo.

Essa etapa foi desenvolvida em duas aulas. Nela propusemos que comparassem ângulos, sem que, para isso, indicássemos um método para tanto e sem fazer uma discussão prévia com a turma sobre esse assunto. Imaginamos que, de posse das folhas com os triângulos desenhados, os alunos recorressem à sobreposição dos ângulos. Porém, constatamos que, unanimemente, quiseram medi-los utilizando régua. Apenas um aluno dispunha de transferidor, mas desistiu de utilizá-lo por não saber como funcionava como instrumento de medida de ângulos. Nesse momento foi necessária uma primeira intervenção do professor no sentido de esclarecer e discutir sobre os métodos por eles utilizados, que foram os seguintes.

a) Utilizando o transferidor

Um grupo mostrou dificuldade em utilizar o instrumento de medida por desconhecimento de como posicioná-lo ou devido a erro de leitura. Acabaram por reconhecer a inviabilidade em utilizá-lo, pois os lados de alguns triângulos eram muito 
pequenos em relação ao tamanho do transferidor. Nesse caso, o professor sugeriu que utilizassem alguma outra técnica para medir os ângulos.

\section{b) Utilizando a régua}

Todos os outros grupos tomaram a atitude de medir os ângulos com régua tomando dois pontos aleatórios sobre dois lados consecutivos e medindo as distâncias entre esses pontos, como no triângulo à esquerda da figura a seguir:
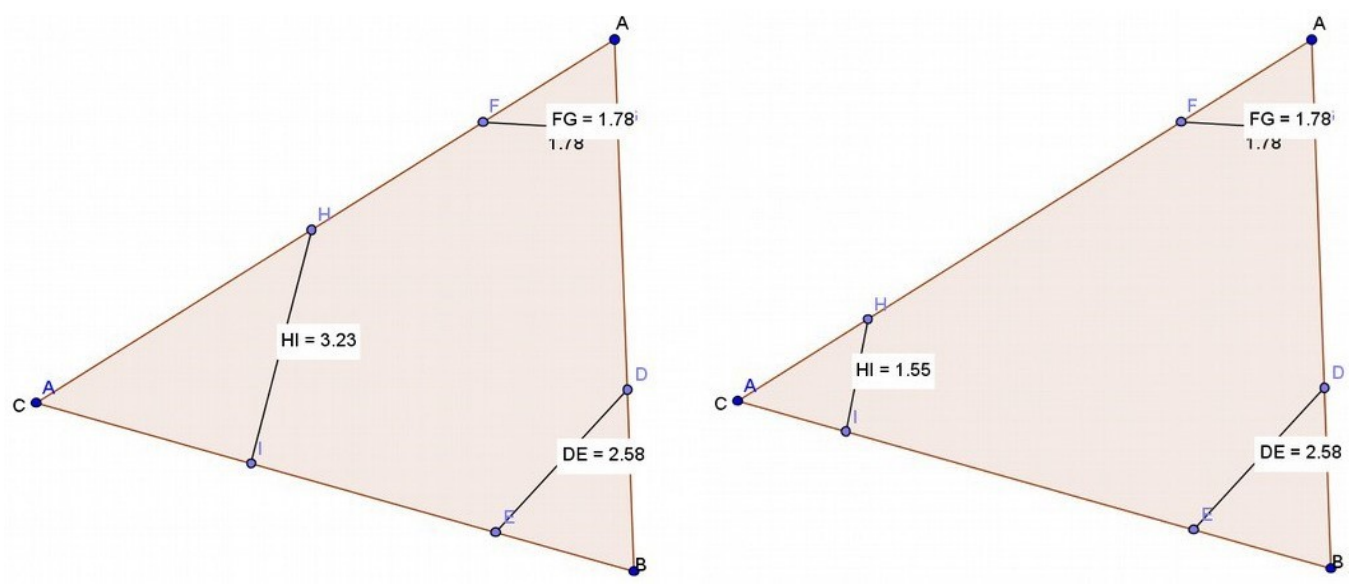

Figura 7 Refutação para o método utilizado pelos alunos para comparar ângulos utilizando régua

Com essa metodologia, ficou estabelecido por mais de um grupo que, por exemplo, $\mathrm{c}<\mathrm{a}<\mathrm{b}$, onde $\mathrm{c}=\mathrm{HI}, \mathrm{a}=\mathrm{FG} \mathrm{e} \mathrm{b}=$ DE. Estando clara a necessidade dos alunos obterem valores numéricos para as medidas dos ângulos, foi necessário questionar a validade do método de medir ângulos com régua. Inicialmente arguimos que esse instrumento serve apenas para medir segmentos, sendo que ângulos são arcos - não funcionou. Na tentativa de que percebessem uma contradição com a desigualdade encontrada e assim questionassem esse procedimento, trocando as folhas, solicitamos que cada grupo medisse novamente os ângulos dos triângulos de outro grupo, pois poderiam encontrar relações distintas das obtidas pelos colegas. Se todos obtivessem as mesmas desigualdades, nós os confrontaríamos, apresentando uma situação hipotética e contraditória com as deles.

Feita a troca e as novas mensurações, ocorreu o previsto na segunda hipótese, pois o resultado obtido pelo grupo original "viciou" a resposta dos outros - que encontraram valores diferentes das medidas dos ângulos, embora mantendo a mesma relação entre os 
mesmos. Questionados se a relação encontrada estava correta, foram incisivos sobre a certeza do resultado, pois haviam confirmado as respostas com os diferentes grupos. Nesse momento, passamos a um debate conjunto com o grupo da sala. Tomamos na lousa dois novos pontos $\mathrm{H}$ e I sobre os lados $\overline{\mathrm{CA}} \mathrm{e} \overline{\mathrm{CB}}$ do triângulo de um dos grupos (ver triângulo à direita na figura 6), de forma a obter outra desigualdade. Com régua, medimos os três segmentos que uniam os pontos de lados consecutivos, assim como eles haviam procedido com seus triângulos, obtendo agora que $\mathrm{a}<\mathrm{b}<\mathrm{c}$.

Questionamos se o procedimento foi igual ao que propuseram, e eles confirmaram. Diante do fato que o a mesma metodologia acarretou duas respostas diferentes, os alunos entenderam que seu método era falho, pois se a régua fosse posta em pontos diferentes obteriam diferentes resultados. No entanto, alunos de dois grupos argumentaram que poderiam aperfeiçoá-lo, estabelecendo uma distância padrão a partir dos vértices para marcar os pontos. Tomaram um compasso e com uma abertura fixa marcaram distâncias a partir dos vértices. Ao experimentarem o novo método, logo perceberam que não poderiam fechar o compasso sob pena de perder o padrão.

Fizemos uma nova intervenção. Perguntamos sobre a necessidade de medir para comparar os ângulos. Como a resposta foi positiva, tomamos dois alunos de diferentes estaturas, colocando-os lado a lado. Pedimos que comparassem suas alturas. Rapidamente perceberam que não há a necessidade de conhecer as medidas das alturas: foi unânime a resposta sobre quem era o aluno de maior estatura.

Com isso, o próximo passo foi desafiá-los a estabelecerem a relação entre os ângulos sem fazer as medições. Perceberam que colocar os ângulos um ao lado do outro era ineficiente. Em pouco tempo um aluno conseguiu dobrar a folha de modo a sobrepor uma metade de um dos lados sobre a outra de forma a fazer coincidir dois vértices adjacentes a este lado do triângulo. Olhando contra a luz, percebeu que um ângulo estava contido no outro, sendo, portanto, menor. O resultado foi compartilhado com os outros grupos. Após alguma discussão sobre a validade do novo método, convencionou-se que, de fato, para comparar ângulos de quaisquer triângulos, bastaria sobrepô-los.

Posteriormente, entendemos que o resultado teria sido mais facilmente atingido por vários alunos se houvéssemos entregado triângulos já recortados, ao invés de apenas desenhados em uma folha de papel sulfite. Percebemos que não ter entregado os triângulos já recortados pode tê-los induzido a não experimentar ou pensar em dobraduras, mas apenas a usar material de desenho (lápis, régua, compasso e transferidor). O que se constituiu, portanto, em um obstáculo didático. 
Etapa 3: Sistematização dos resultados

Essa etapa, desenvolvida em uma aula, teve por objetivo a socialização e a sistematização dos resultados obtidos. Os alunos sentiram necessidade de adotar uma mesma notação para vértices e ângulos. Sugeri a usual, ou seja, colocar letras maiúsculas para ângulos e minúsculas para as suas respectivas medidas, bem como a utilização dos símbolos matemáticos para representar desigualdades. Representar os vértices por letras maiúsculas, assim como nomear os ângulos, foi um fato importante percebido pelos alunos, pois tornou mais eficiente a explicitação de seus resultados, escrita e oralmente, principalmente depois de muitos terem registrado seus resultados em português para expressarem as comparações entre ângulos, elaborando textos muito longos.

Coletados os dados, e sistematizados na lousa, os três tipos de triângulo obtidos foram:

a) 3 lados de medidas iguais com três ângulos internos também de mesma medida;

b) 2 lados com medidas iguais, assim como dois ângulos de mesma medida;

c) 3 lados de medidas diferentes, assim como ângulos de medidas também diferentes.

A partir desses resultados, pudemos estabelecer uma nomenclatura para os triângulos, classificando-os pelas medidas de seus lados como equiláteros, isósceles e escalenos, respectivamente. Também foi observado que o número de lados de mesma medida corresponde à mesma quantidade de ângulos, também de mesma medida.

Etapa 4: Prova do resultado que afirma: a soma dos ângulos internos de um triângulo qualquer é $180^{\circ}$.

Nessa etapa, desenvolvida em quatro aulas, um objetivo inicial foi determinar uma das alturas internas para cada triângulo, que agora os alunos dispunham em mãos já recortados. Isso porque pretendíamos que chegassem experimentalmente ao resultado desejado, fazendo dobraduras para constatarem que os três ângulos interno podem juntos compor um ângulo raso. Para viabilizar tal dobradura torna-se necessário determinar o pé de uma altura interna.

Para tanto fizemos uma intervenção inicial definindo altura como a distância de um vértice ao lado oposto. A partir de minha fala, na qual não demos a definição de distância de 
ponto à reta, não foram poucos os alunos que fizeram medidas, com régua, de vários segmentos aleatórios, unindo pontos da base com o vértice, conforme figura 7 .

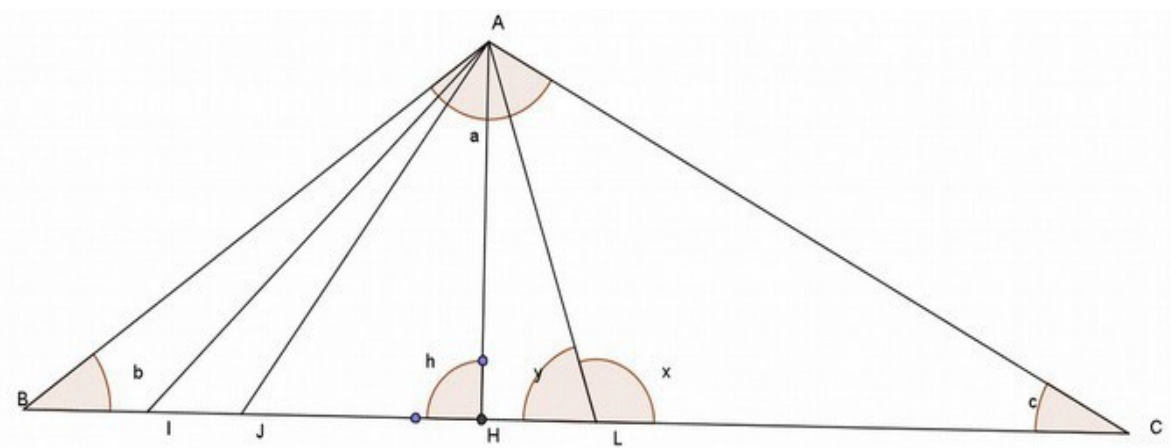

Figura 8 Identificação e determinação do segmento de menor comprimento que une o vértice A ao lado BC

Todos os segmentos no interior do triângulo foram adotados como distância entre o vértice $\mathrm{A}$ e o lado $\mathrm{BC}$ do triângulo. Alguns alunos perceberam a necessidade de se estabelecer um padrão. Citando o comentário de um deles: “Caso contrário, se eu entregar meu triângulo para outra pessoa ela encontrará outra medida para a altura, sendo que a maior delas seria atingida à medida que fossemos para esquerda ou direita coincidindo com o respectivo lado do triângulo".

Terminada essa discussão, fizemos outra intervenção, apresentando a seguinte analogia: "se você morasse em A e tivesse que caminhar até a rua $\mathrm{BC}$, por qual caminho você iria? " Foi unânime a resposta que seria pelo "mais curto". A pergunta então, ficou: como determinar esse caminho mais curto?

Desenhamos os segmentos AI e AJ (ver figura 7) no quadro pedindo que os comparassem visualmente e, sem nenhuma objeção, o segmento AI foi dito ser maior que o AJ. O mesmo foi feito com os segmentos AH e AL. Ao compararem AJ com AH foi logo percebido por alguns que, caminhando para a direita a medida dos segmentos diminuem. Porém, a afirmação falhava para $\mathrm{AH}$ e AL, pois o segundo é maior que o primeiro.

Entendendo que estávamos prestes a encontrar um método para determinar a menor distância entre o vértice $\mathrm{A}$ e o lado $\mathrm{AB}$, desenhamos o ângulo x destacado na figura 7 . Perguntamos aos alunos como se comportava a medida de tal ângulo. De forma rápida e geral disseram que "para a direita aumentava e se fosse para a esquerda diminuía" e que, conforme um dos alunos, “com o ‘irmão dele’, o ângulo y, ocorria o contrário”. 
De posse dessas observações o próximo passo dado pelos estudantes foi perceber que, em algum ponto, esses pares de ângulos 'irmãos' seriam iguais. Nesse momento foi possível estabelecer o consenso sobre qual deve ser o segmento que chamamos de altura do triângulo relativamente ao lado $\mathrm{BC}$, ou seja, o menor dos segmentos internos desenhados naquele triângulo com extremidades no vértice $\mathrm{A}$ e um ponto em $\mathrm{BC}$. Terminando por definirem a altura corresponde ao segmento que determina pares de ângulos iguais com lado BC em questão, ou seja, AH na figura 7.

O passo seguinte foi determinar os pares de ângulos de mesma medida para determinar o ângulo reto por dobradura. Entreguei uma folha de sulfite com um segmento desenhado e após algumas experiências, uma aluna decidiu dobrar o papel sobre si mesmo de tal forma que os extremos da linha desenhada coincidissem. Pedimos à aluna que compartilhasse seu raciocínio de dobrar a folha e sobrepor uma parte do segmento sobre si próprio e sua resposta foi que só repetiu o procedimento que estávamos utilizando.

Nesse momento orientamos os demais estudantes para que fizessem o mesmo procedimento e que, além de sobreporem os segmentos, destacassem o vinco (dobra) da folha, marcando os ângulos "irmãos" (de mesma medida). Perceberem rapidamente que a sobreposição de uma parte do seguimento sobre a outra determina pares de ângulos de mesma medida independentemente do ponto onde o segmento é dobrado. Ou seja, descobriram como determinar um ângulo reto com dobraduras. Além de se apropriarem do procedimento, ficou claro para eles que esse par de ângulos de mesma medida tem sempre o mesmo valor do ângulo reto, de $90^{\circ}$.

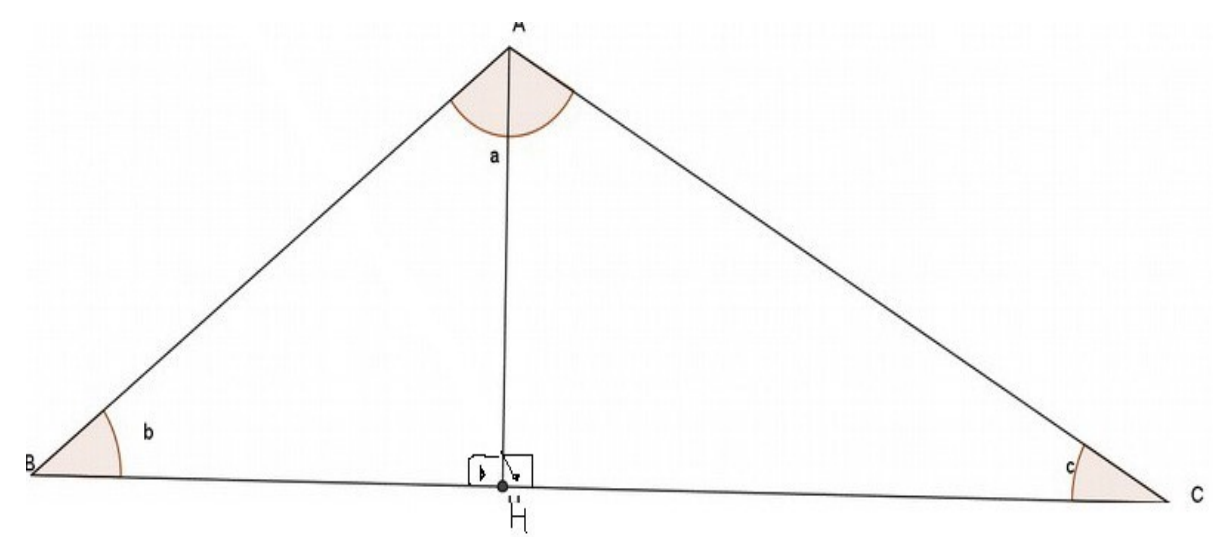

Figura 9. Determinação e identificação da altura do triângulo como o seguimento de menor comprimento que une o vértice $\mathrm{A}$ ao lado BC. 
Construído o segmento que chamamos de altura para os três triângulos, voltamos à tarefa de determinar a soma dos ângulos internos do polígono. A atividade seguinte foi dobrar o triângulo fazendo os vértices $\mathrm{A}, \mathrm{B}$ e C coincidirem com o ponto H (pé da altura).

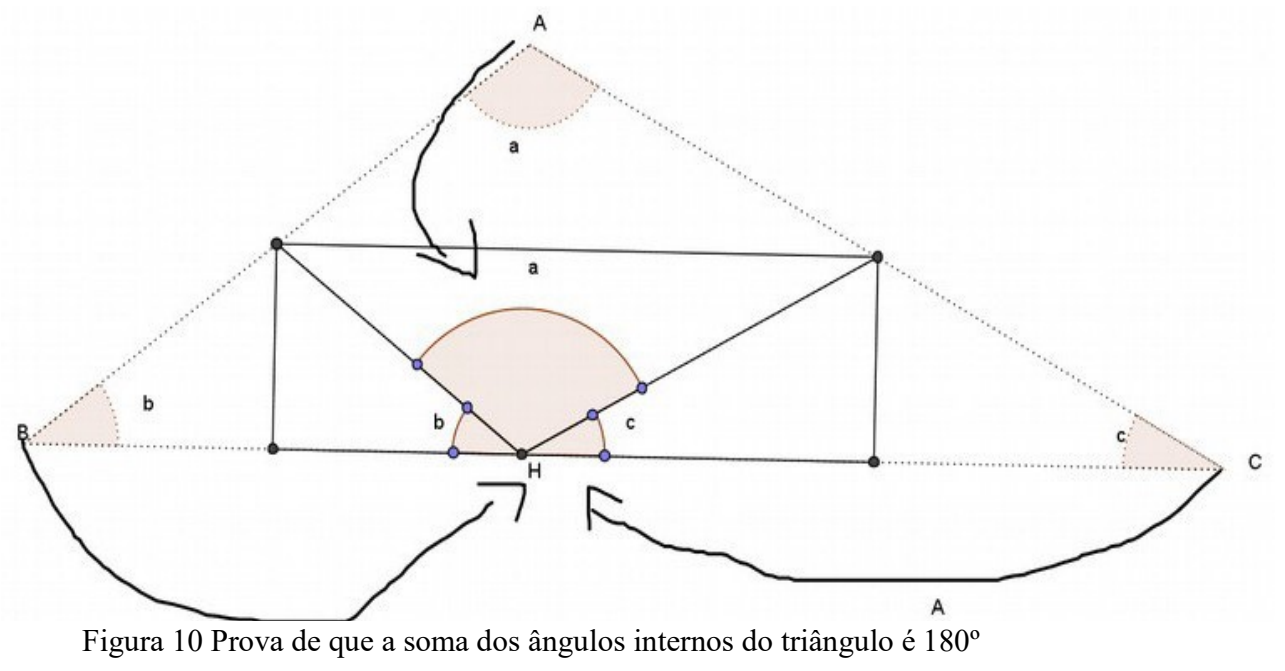

As setas da figura 9 indicam a direção em que se deve dobrar a folha para coincidir os vértices $\mathrm{A}, \mathrm{B}$ e $\mathrm{C}$ com o ponto $\mathrm{H}$. Fizemos também o mesmo com os ângulos $\mathrm{a}, \mathrm{b}$ e c, compondo a totalidade: $\mathrm{a}+\mathrm{b}+\mathrm{c}=180^{\circ}$.

A partir da repetição desse procedimento para todos os triângulos que os grupos tinham em mãos, comprovamos que a soma dos ângulos internos de todos os triângulos da sala era $180^{\circ}$ para todos os triângulos de todos os tipos.

Etapa 5. Determinação da soma dos ângulos internos de um polígono convexo qualquer

Essa etapa foi desenvolvida em duas aulas. Foi proposta uma atividade para que determinassem a soma dos ângulos internos de qualquer polígono convexo a partir do resultado previamente estabelecido para triângulos. Nessa etapa, a discussão se deu por meio de um debate coletivo, com a totalidade da classe.

Inicialmente desenhamos no quadro as figuras de um quadrilátero, de um pentágono e um hexágono, nenhum deles regular. A partir disso, propusemos a seguinte questão: como determinar a soma dos ângulos internos desses polígonos utilizando o resultado anterior para triângulos? Nosso propósito era que vivenciassem uma situação de inferência a partir de uma premissa tomada como hipótese. 
Os primeiros polígonos que analisaram foram um quadrilátero e um pentágono. Poucos alunos (quatro no total) conseguiram descobrir que bastava decompor a figura em triângulos e comunicaram suas descobertas fazendo suas decomposições no quadro. A partir daí todos os demais estudantes perceberam que esse procedimento lhes permitia utilizarem o resultado anterior para determinar a soma dos ângulos internos dos dois polígonos em questão. Ou seja, o método foi facilmente assimilado por todos, pois puderam perceber que a justificativa estava solidamente estabelecida, a partir do resultado prévio, inclusive para o hexágono.

Tomamos a iniciativa de fazer uma tabela com esses dados na qual se explicitava: o polígono, sua quantidade de lados e a quantidade de triângulos em que a figura foi decomposta. Dado isso, houve até o caso de um grupo que determinou a soma dos ângulos internos de um icoságono (polígono de 20 lados), sem apoio em figuras, pois generalizou intuitivamente o resultado.

\section{Análise da Prática Didática}

Preliminarmente, concluímos que as atividades atingiram os seguintes objetivos com os estudantes: vivenciaram a construção de conceitos, definições matemáticas e propriedades geométricas; vivenciaram um processo de validação exercitando explicações, refutações e provas; exercitaram, na prática, as capacidades de levantar hipóteses e argumentar, diante da necessidade de discernir sobre a validade ou não de respostas às questões e desafios formulados; tiveram uma experiência significativa com a inferência lógica em Geometria. Em algumas situações criou-se um fórum para debate crítico. Ou seja, as atividades foram significativas quanto ao nosso propósito inicial de propor situações didáticas que pudessem propiciar vivências escolares favoráveis ao desenvolvimento de seu senso crítico e, com isso, pudessem representar alguma contribuição ao processo de formação para o exercício da democracia e da cidadania.

A análise que fazemos da prática didática desenvolvida baseia-se nos trabalhos de Skovsmose (2000), Balacheff (1988) e Van Hiele (Crowley, 1994). Mais especificamente, situamos o ambiente de aprendizagem das atividades desenvolvidas em um cenário para investigação em Geometria (como proposto pelo primeiro autor) e analisamos o desenvolvimento dos estudantes relativamente ao uso de provas pragmáticas de Balacheff e através dos níveis de Van Hiele (Crowley, 1994). Conforme já discutimos anteriormente, no 
capítulo IV, a metodologia e a sequência didática propostas para o desenvolvimento das atividades favorecem a progressão pelos níveis de Van Hiele, cuja análise detalhamos a seguir (em especial observando as fases de aprendizado). Ainda, nesse caso, criamos um ambiente de argumentações e refutações entre os alunos para negociar significados, estabelecendo um ambiente democrático em sala de aula.

No contexto dessa sequência didática descrita anteriormente, foi predominante a produção de provas pragmáticas pelos alunos. Para exemplificar, podemos citar a prova da propriedade de que a soma dos ângulos internos de um triângulo é sempre $180^{\circ}$ ou a percepção que tiveram sobre a relação entre número de lados e ângulos de mesma medida em um triângulo. Em particular nesses dois casos, a apreciação do caráter geral da prova pelo educando demanda a utilização de outros recursos na sua construção, como linguagens e relações que assim o permitam: no primeiro caso, o teorema das paralelas cortadas por uma transversal conforme enfatizamos no capítulo IV, e no segundo caso, conhecimentos dos casos de congruência de triângulos. Também no caso da construção do segmento que definimos como altura do triângulo, houve uma produção de prova pragmática, pois nenhuma relação geral entre o ângulo de $90^{\circ}$ e o comprimento mínimo desse segmento foi formalizada. Por outro lado, o método de sobreposição dos ângulos que permitiu estabelecer uma relação de desigualdade entre suas medidas foi claramente entendido com tendo um caráter geral.

Apesar disso, buscamos a todo o momento o desenvolvimento do educando no sentido de fazê-lo tomar posse do caráter geral das afirmações. Num primeiro momento, houve a tentativa de centrar as afirmações sob o maior número de triângulos possíveis e para tanto lançamos mão de trabalhar com a classificação de triângulos. Nosso propósito com isso foi estimular com que os alunos fizessem suas afirmações sobre os tipos de triângulos (equiláteros, isósceles e escalenos) generalizando os resultados obtidos. Apesar das propriedades e conceitos que foram construídas e consequentemente apropriadas pelos educandos de forma ingênua, não podemos dizer que seus trabalhos se situam inteiramente no nível de empirismo ingênuo, mas em situação de transpor as provas pragmáticas em direção à construção de provas conceituais. Dessa forma, ficou nítida a conscientização dos alunos sobre a validade geral do resultado, independentemente dos formatos dos triângulos particulares. 


\section{Nível 0: Visualização}

Observando a fase 1 do aprendizado, começamos com uma pergunta sobre quais impressões os alunos tinham sobre o valor da soma dos ângulos internos de triângulos de vários tamanhos. De modo geral, a resposta foi que a soma dependia dos comprimentos de seus lados. Posto isso, concluímos que os alunos se encontravam no nível 0 de Van Hiele no que se refere a essa atividade, pois observaram cada triângulo isoladamente, sem estabelecer relações entre eles. Embora não fizesse parte dos objetivos iniciais da sequência didática, pudemos perceber que os alunos tampouco tinham domínio ou conhecimento da classificação de triângulos segundo a medida de seus lados. Ou seja, pudemos diagnosticar que este conteúdo também precisava ser assimilado.

Sobre a questão de compararem as medidas dos ângulos de um mesmo triângulo, o fato de utilizarem régua na medição (e acreditarem em sua resposta) pode ser caracterizado como um caso de empirismo ingênuo. Para orientar os alunos quanto à execução dessa tarefa (fase 2), a discussão de contraexemplos, feita para refutar tal estratégia que adotaram, levouos a perceberem a ineficácia do "método da régua", colocando a necessidade de outro método para a comparação. O estabelecimento dessa refutação constituiu naquilo que Balacheff chama de prova do tipo experimento crucial. A comparação por sobreposição dos ângulos proporcionou um método de validação mais geral, constituindo-se, por sua característica de validação de uma afirmação por meio de uma prova conceitual. Segundo Balacheff (1987), uma situação como essa produz uma mudança nas concepções dos alunos quanto à busca por uma resposta geral e aceita por todos, o que de fato aconteceu com o grupo de alunos.

Na sequência da atividade que descrevemos no parágrafo anterior, o fato da situação proposta ter levado os educandos a perceberem a necessidade do uso de notação para os elementos dos triângulos foi outro aspecto a ser observado nessa atividade, o que é uma atitude própria do nível de visualização, própria à fase 3. Além disso, para as comparações das medidas de ângulos e de segmentos entre si, foi útil estabelecer as desigualdades e fixar nomes para os ângulos com uma simbologia mais econômica, pois a língua materna tornouse inviável para um bom registro devido à extensão demasiada das frases (fase 4). Finalmente, com o objetivo de sistematizar seus resultados, criou-se ainda a necessidade de estabelecer uma linguagem simbólica que facilitasse o registro, surgindo a opção de nomear ângulos e vértices com letras latinas e símbolos matemáticos para desigualdades, fazendo 
com que a linguagem da comunicação dos fatos se tornasse natural e significativa para os alunos (fase 5).

Nível 1: Análise

A discussão prévia à obtenção de consenso entre os alunos sobre qual segmento caracterizava a menor distância entre o vértice e o lado oposto ao mesmo foi bastante rica do ponto de vista pedagógico. Em meio aos debates surgiu a questão sobre como determinar a altura solicitada (fase 1). Assim, ao longo deste trecho da sequência didática, negociamos a introdução de conceitos e propriedades geométricas por meio de argumentações (fase 2). O desconhecimento do conceito de altura de um triângulo pelos estudantes foi por nós inesperado. Mas a construção do segmento correspondente foi um momento importante, pois se constituiu em um primeiro fórum de debate crítico espontâneo entre os alunos. Dessa forma, quanto ao conceito de altura, pudemos identificar que os estudantes tangenciaram uma prova do tipo conceitual, mais especificamente do tipo exemplo genérico, ao relacionarem o segmento que realiza a menor distância entre um vértice e o lado oposto do triângulo como sendo aquele que determina um ângulo de reto com o respectivo lado (fase 3). Também não esperávamos que os alunos não conhecessem os conceitos de ângulo total, raso e reto. Cabe destacar que no que se refere à construção do ângulo reto, outro debate crítico foi criado. Nesse caso, foi necessário discutir uma ideia, que fosse consenso entre os alunos, e que permitisse construir essa medida com dobraduras. Por meio da atividade manipulativa com dobraduras, observaram que triângulos poderiam ter os três ângulos de mesma medida, dois ângulos de mesma medida ou todos de medidas diferentes. Alguns grupos associaram ainda que os respectivos triângulos tinham três lados de mesma medida, dois lados de mesma medida e todos os lados de medidas diferentes (fase 2). Tais padrões, encontrados por esses grupos, constituíram-se em um caso de prova pragmática do tipo empirismo ingênuo, uma vez que cada novo caso particular ainda demandava validação para a comprovação do padrão (fase 4). A partir do estabelecimento dessas convicções por parte dos alunos, ficou natural nomear os triângulos como equiláteros, isósceles e escalenos, tornando claro que os nomes estavam associados a quantidades de lados de mesma medida que cada tipo possuía, implicando também em igual quantidade de ângulos de mesma medida (fase 5).

Nessas atividades situamos o grupo de alunos no nível 1 de Van Hiele, pois sentiram a necessidade de apropriarem-se de linguagem geométrica, atribuíram significado a novos conceitos geométricos, bem como estabeleceram provas pragmáticas, por meio de 
dobradura, para a verificação de propriedades geométricas, a partir da análise das características das figuras. O processo de dedução informal proposto aos alunos consolidouse na construção da altura de um triângulo e nas discussões sobre a validade geral da relação entre número de lados e ângulos iguais, situação que qualificamos como exemplo genérico, o que impulsionou a transição para o nível 2 de Van Hiele.

Nível 2: Dedução Informal

Por fim, por meio das provas construídas no debate conjunto, os alunos vivenciaram uma importante comunicação baseada em linguagem matemática, na qual a simbologia empregada ficou repleta de significados para eles e as atitudes exercitadas, de fato, constituíram-se em momentos marcantes, onde desenvolveram noções e experiências das quais poderão lançar mão tanto dentro como fora da Matemática (fase 5). O processo de validação que propusemos aos alunos transformou afirmações, eventualmente desconexas entre si (como a relação entre o menor segmento que une um vértice ao lado oposto do triângulo e o ângulo de $90^{\circ}$ ), em novas definições que delas decorreram - o conceito de altura de um triângulo e o de ângulo reto (fase 3). Podemos dizer que assimilaram a prova, embora não a tenham criado. As definições passaram a ser significativas e, além dos processos de conceituação, raciocínio e utilização de sistemas de expressão mais precisos do que a linguagem natural, outros aspectos relativos à formação integral dos estudantes entraram em jogo, como criticidade e troca de ideias dentro de um clima de respeito às convicções eventualmente distintas (fase 5).

Assim, segundo Dewey, no que concerne às funções da escola, primeiramente pudemos proporcionar um ambiente de aprendizado em que os educandos puderam assimilar conhecimentos gradativamente, respeitados seus ritmos, suas evoluções e suas maturidades, conduzindo-os a uma compreensão significativa de fatos e linguagem matemáticos. Em segundo lugar, esse espaço de discussão em Matemática, conforme definimos anteriormente, ainda que naturalmente desvinculado de preconceitos e ideologias, foi desenvolvido em torno de argumentações que favoreceram respostas ou soluções aos problemas propostos para além do senso comum. Cabe salientar que as discussões em sala criaram um ambiente no qual as decisões e práticas adotadas foram negociadas, optando-se sempre por aquela que conduzia ao melhor resultado, sem interferências de questões pessoais, imposições ou autoritarismo do professor. Em terceiro lugar, conforme Skovsmose (2013, p. 62) criou-se 
uma ponte entre Educação Matemática e democracia, pois o espaço de argumentação pode propiciar o desenvolvimento de recursos que possibilitaram aos alunos agir e refletir livremente na micro sociedade da sala de aula.

A partir do conceito de pensamento ou senso crítico (ver página 24), identificamos que o trabalho de investigação realizado nesse cenário de investigação em Geometria pode contribuir para o processo de desenvolvimento do senso crítico dos educandos. Mais especificamente, nessa atividade propiciamos o desenvolvimento das seguintes características de um pensador crítico, segundo Carraher (ver página 28):

1. Uma atitude de constante curiosidade intelectual e questionamento - em virtude das discussões que ocorreram e do estímulo às descobertas de fatos matemáticos;

2. A habilidade de pensar logicamente - em virtude do aprimoramento de seu raciocínio durante as discussões que envolviam argumentações e refutações, bem como na formulação de conceitos;

5. A consciência pragmática, um reconhecimento e apreciação dos usos práticos da linguagem como meio de realizar objetivos e influir sobre os outros - em virtude da utilização de linguagem pertinente ao contexto matemático para expressar ideias;

6. Uma distinção entre questões de fato, de valor e questões conceituais - em virtude do reconhecimento do que é convencional no contexto trabalhado, como notações e simbologias próprias para a representação e transmissão de ideias, e o reconhecimento de conceitos como a construção do conceito de altura de um triângulo, que é a menor distância entre um vértice e o lado oposto a esse vértice;

7. A habilidade de penetrar até o cerne de um debate, avaliando a coerência de posições e levantando questões que possam esclarecer a problemática - novamente, em virtude do espaço criado em sala de aula, que envolveu argumentações justificadas e refutações.

Por fim, dada a discussão prévia que fizemos nesta dissertação sobre o pleno desenvolvimento, cidadania e, principalmente, sobre senso crítico, temos a convicção de que ao longo desta prática didática em Geometria, conseguimos contribuir para $\mathrm{o}$ desenvolvimento dos educandos quanto a esses três aspectos, que constituem finalidades importantes da Educação Básica, por meio da ocasião que essas atividades criaram para o exercício e o desenvolvimento de pensamento crítico. 


\section{Capítulo VII - Sequência Didática envolvendo Grandezas Medidas e Análise Estatística de Dados em uma turma de $7^{\circ}$ ano do Ensino Fundamental: a crise hídrica como cenário de investigação}

Esta sequência didática foi motivada por questões suscitadas por atividade didática desenvolvida com a mesma turma de $6^{\circ}$ ano do capítulo anterior (em 2015) sobre grandezas cujas unidades de medidas são expressas por razões entre duas unidades de medidas de outras grandezas (como velocidade e vazão). Tais atividades fizeram parte de atividades regulares com meus alunos, sem relação direta com a investigação para esta dissertação. Por completude, e para melhor compreensão do trabalho feito no ano seguinte (2016), passamos a descrever brevemente as atividades inicialmente trabalhadas para, a seguir, focarmos na descrição e análise da prática didática desenvolvida intencionalmente no contexto da nossa investigação sobre possibilidades de trabalho escolar envolvendo argumentações com Matemática. Ou seja, a sequência didática abordada neste capítulo foi desenvolvida com a mesma turma daquela discutida no capítulo anterior, agora no $7^{\circ}$ ano do Ensino Fundamental, acrescida de novos alunos, que puderam acompanhar a proposta sem problemas.

No segundo semestre de 2015, as atividades propostas, pertinentes ao bloco grandezas e medidas, visaram o entendimento dos alunos sobre o uso crítico dos números em práticas sociais, particularmente, sobre a necessidade do emprego de medidas expressas por razões. Esse trabalho foi realizado com a mesma turma de $6^{\circ}$ ano que participou do experimento em Geometria, realizado no primeiro semestre de 2015.

A discussão começou sobre o tipo de informação que podem fornecer as unidades de medidas fundamentais de comprimento (metro), tempo (segundo) e volume (metro cúbico), e unidades de medidas delas decorrentes por razões, como as que indicam velocidade e vazão. Por exemplo, dizer que um indivíduo percorreu 45 quilômetros é uma informação distinta daquelas que dizem que o mesmo percorreu 45 quilômetros em uma ou duas horas. A discussão da noção de velocidade instantânea não foi discutida, pois o foco era mostrar como a informação se modifica ao relacionarmos duas unidades de medidas por uma razão. Outra situação abordada foi a unidade que explicita a medida da vazão. As quantidades de água demandadas em um banho por duas pessoas podem ser comparadas observando o 
volume de água gasto. Assim, para indivíduos que necessitam de 101 e 151 de água para seus banhos, respectivamente, é fácil observar que o segundo tem um gasto maior. No entanto, se a informação dada for somente sobre o tempo de duração dos banhos, por exemplo, 10 minutos e 15 minutos, não se pode concluir quem gastou mais água, pois depende da vazão de água dos chuveiros.

$\mathrm{Na}$ sequência dessa discussão, para que os alunos se apropriassem do conceito de vazão, propus o seguinte desafio: como medir, em litros, a quantidade de água despendida por uma pessoa em um banho? Rapidamente, perceberam a inviabilidade de se armazenar e medir toda a água utilizada. Sem fornecer-lhes muitas explicações, sugeri que recolhessem a água que sai do chuveiro durante um minuto. Determinando assim, uma estimativa da vazão do chuveiro em litros por minuto. A seguir, propus que elaborassem uma medição experimental da vazão de água dos chuveiros de suas casas ao longo de uma semana típica e a quantidade de água gasta em banhos pela família, identificando o gasto individual de cada membro. A título de ilustração, segue uma tabela construída por um aluno que exibe a vazão de água de seu chuveiro e o tempo de banho de seus familiares.

\section{Consumo de água dos familiares}

$\begin{array}{llllll} & \text { Segunda } & \text { Terça } & \text { Quarta } & \text { Quinta } & \text { Sexta } \\ \text { Pai } & 7 \mathrm{~min} & 8 \mathrm{~min} & 7 \mathrm{~min} & 7 \mathrm{~min} & 6 \mathrm{~min} \\ \text { Mãe } & 8 \mathrm{~min} & 7 \mathrm{~min} & 10 \mathrm{~min} & 8 \mathrm{~min} & 11 \mathrm{~min} \\ \text { Irmã } & 10 \mathrm{~min} & 9 \mathrm{~min} & 8 \mathrm{~min} & 15 \mathrm{~min} & 7 \mathrm{~min} \\ \text { Aluno } & 15 \mathrm{~min} & 9 \mathrm{~min} & 7 \mathrm{~min} & 11 \mathrm{~min} & 13 \mathrm{~min}\end{array}$

\section{Vazão: $4 \mathrm{l} / \mathrm{min}$}

Tabela 2 Tempos de banho de familiares de aluno do $6^{\circ}$ do E.F.

Tudo isso foi motivado pelo contexto da crise hídrica pela qual passou o Estado de São Paulo no período de 2015. As constantes orientações do governo estadual, seguidas das notícias veiculadas pelas mídias, para que a população diminuísse seu consumo de água reforçavam o consenso de que a falta de água é causada pelo desperdício da população. Dessa forma, de posse das tabelas de dados por eles construídas e pela abordagem específica sobre unidades de volumes como litro e metro cúbico, trabalhamos com as seguintes questões a serem respondidas pelos alunos: qual o gasto mensal de água de sua família? Examinando as contas de água da residência em vários meses sucessivos, você pode concluir se o gasto de água de sua família é alto ou baixo? Justifique dizendo em que critério você se baseou para responder a última questão. 
Para responder a essas perguntas, muitos alunos verificaram inicialmente o volume de água gasto, indicado em suas contas de água. Quanto a responder se o volume é alto ou baixo, muitos também responderam que é alto. Questionados sobre o critério utilizado para emitir seus julgamentos, obtivemos as seguintes respostas:

- Porque o valor da conta está alto;

- Porque o governo está mandando economizar;

- Porque o gasto familiar está acima valor da taxa mínima.

Nitidamente, suas respostas estavam contaminadas por falas das próprias famílias, pela repetição de notícias fornecidas pelas mídias ou pelo governo. Além disso, suas respostas levaram em consideração apenas aspectos individuais de consumo, ou seja, em nenhum momento algum aluno tomou a iniciativa de observar o consumo de outro colega para poder comparar com o seu. Assim, coloquei alguns valores das contas de água de 10 alunos na lousa e pedi que todos da sala avaliassem qual representava o maior consumo. Naturalmente, o maior valor exposto no quadro correspondeu ao maior volume gasto daquele grupo. Porém, alguns alunos observaram que esta análise dependia do tamanho da família. Por exemplo, famílias com 5 componentes, naturalmente demandam um maior consumo que outra com 2 componentes apenas. Nesse sentido, uma situação interessante a relatar consistiu num caso em que dois alunos apresentavam o mesmo valor de consumo de água e que competiam sobre quem gastava menos se baseando no número de pessoas em cada uma de suas residências. Como uma família possuía um membro a mais que a outra, um aluno desta família reivindicou que seu consumo era menor. Porém, o outro argumentou que seu pai tomava dois banhos por dia e, portanto, deveria ser considerado como mais uma pessoa na residência. Assim argumentou que a comparação não era justa. Sem detalharmos mais essa conversa com o grupo de alunos, ficou claro que outros parâmetros tinham que ser utilizados para uma avaliação familiar do consumo de água. Outro ponto é que essa provocação fez com que os alunos interagissem mais com a atividade, contribuindo para o desenvolvimento da mesma.

De modo geral, essas pequenas discussões foram significativas e subsidiaram os alunos momentaneamente na avaliação do nível de seu consumo hídrico. Nesse caso, os estudantes, em sua maioria, concordaram que a comparação ficaria mais fácil se fosse relativa a uma única pessoa da família. Por outro lado, em se tratando de alunos de $6^{\circ}$ ano, outras provocações que objetivavam descobrir quantos litros de água cada indivíduo de sua 
família consome ou se o consumo individual é alto ou baixo, tornou-se infrutífera, acredito que por falta de bagagem teórica dos alunos para avançar na discussão e talvez por extrapolar a maturidade ou o interesse dos jovens da faixa etária em questão. Observando que o trabalho se tornava cansativo para os alunos, decidi encerrá-lo, haja vista que muitos deles se dispersavam em conversas aleatórias entre si ou até mesmo me perguntando se poderiam fazer outra tabela mais colorida. Guardei as planilhas feitas por eles, com a convicção de ser importante aprofundar a análise dos mesmos dados no $7^{\circ}$ ano, por meio de outras atividades didáticas com os mesmos alunos.

Nas novas atividades para o $7^{\circ}$ ano, o fato de estarem em nível escolar posterior permitiu avançar mais nas discussões sobre os gastos individuais dos familiares e responder à questão sobre se seu consumo era alto ou baixo. Nessa altura, os alunos já sabiam trabalhar com porcentagens e médias aritméticas, permitindo que pudessem estabelecer comparações além daquelas observadas somente com números inteiros. A seguir, descrevemos a sequência didática desenvolvida no primeiro semestre de 2016 em todas as suas etapas, considerando que as etapas 1 e 2 ocorreram no $6^{\circ}$ ano e as seguintes ocorreram no $7^{\circ}$ ano, já com os novos alunos ingressantes na turma familiarizados e inseridos na discussão.

\section{VII.I A Sequência Didática e sua Aplicação em Sala de Aula}

Os objetivos desta sequência foram: trabalhar com grandezas, medidas e razões (as duas primeiras etapas realizadas no $6^{\circ}$ ano) e levantamento, organização e tratamento de dados para análise estatística (as três últimas etapas realizadas no $7^{\circ}$ ano).

Elaboramos o seguinte plano de aula, que norteou a aplicação das atividades. Salientamos que as contribuições de Ole Skovsmose sobre o Poder Formatador e a Ideologia da Certeza em Matemática representaram uma forte motivação para as três últimas etapas dessa prática didática.

\section{Objetivo geral da sequência didática}

Trabalhar argumentações com Matemática a partir de contexto social real e relevante, buscando o desenvolvimento do uso crítico de ferramental estatístico para a análise da situação e provocar uma reflexão ou avaliação sobre afirmações recorrentes nas mídias sobre a crise hídrica. 


\section{$\underline{\text { Objetivos específicos da sequência didática }}$}

Assegurar a apropriação pelos alunos de conceitos de medidas de volumes (litro e metro cúbico) e de vazão (litros por minuto). Discutir o uso e aplicação dos mesmos no cotidiano e nos diversos contextos sociais, compreendendo a realidade em que estão inseridos. Introdução a uma análise estatística de dados. Fornecer um conhecimento global que possibilite uma atuação em espaços outros que aquele da sala de aula.

\section{Metodologia}

Pesquisas e atividades a partir de algumas questões surgidas em sala de aula e também propostas pelo professor, com posterior discussão dos resultados com o grupo da sala. Utilização de planilhas eletrônicas. Aulas dialogadas garantindo amplo espaço para a exposição das ideias propostas pelos alunos.

\section{$\underline{\text { Material }}$}

Contas de água das famílias dos alunos envolvidos (de alguns meses consecutivos), tabelas elaboradas em planilhas eletrônicas a partir de dados coletados pelos alunos, papel, lápis, calculadora, sala de informática.

\section{$\underline{\text { Organização }}$}

Os alunos trabalharam em grupos de 4 ou 5 integrantes, houve debates com os grupos individualmente e, posteriormente, um debate conjunto com o grupo da sala de aula e conduzido pelo professor.

Número de aulas previstas: 18 aulas.

A descrição da aplicação do experimento foi baseada em registros das observações do professor ao longo das aulas. Não nos foi viável gravar as aulas seja em áudio ou em vídeo. Segue o relato dos trabalhos desenvolvidos efetivamente em sala de aula.

\section{Desenvolvimento das Atividades Didáticas}

Etapa 1 - Aferição do volume de água por unidade de tempo ( $2^{\circ}$ semestre de $2015-6^{\circ}$ ano $)$

Essa etapa, realizada em duas aulas, começou com uma discussão sobre unidades de medidas de comprimento, tempo e volume, com o objetivo de explicitar outras grandezas expressas por razões obtidas a partir das primeiras. A ideia inicial foi mostrar aos alunos a importância de fazerem uso de razões pela relevância da informação que a mesma pode 
transmitir aos interessados. Por exemplo, dizer que um indivíduo percorreu 100 quilômetros ou que o mesmo percorreu 100 quilômetros em uma hora $(100 \mathrm{~km} / \mathrm{h})$ traz informações distintas, sendo que a segunda (que expressa a velocidade) traz uma informação mais completa sobre a situação. No primeiro caso, a simples menção da distância percorrida não oferece elementos para avalia-la em um contexto específico. A mesma discussão foi feita sobre a importância da explicitação de vazões e outras razões que os alunos acharam pertinentes, como expressar o desempenho de um automóvel por meio da relação entre distância percorrida e volume de combustível despendido $(\mathrm{km} / \mathrm{l})$, a relação entre volume e preço de combustível, etc. Assim, com o intuito de tornar mais significativa as ideias expressas por razões, encaminhamos o experimento.

Uma ideia que surgiu foi determinar o tempo que as torneiras e chuveiros ficavam abertas para uso, que logo foi recusada pelo grupo, porque seria difícil medir a vazão de água para beber e para lavar roupas, pois as mesmas eram lavadas na máquina. Sugeri então que começássemos pela aferição do volume de água utilizado para tomar banho, o que suscitou questionamentos sobre a possibilidade de haver desperdícios. Para evitar tais transtornos com as famílias dos alunos, pedi que verificassem a quantidade de água vertida pelo chuveiro em um (1) minuto. Forneci instruções sobre como deviam fazê-lo e um prazo para efetuar a tarefa. Expusemos todos os resultados obtidos pelos alunos na lousa para uma discussão. A seguir, registramos as medições de alguns alunos. Os resultados estão em litros por minuto $(\mathrm{l} / \mathrm{min})$.

\section{$4 \mathrm{l} / \mathrm{min} \quad 5 \mathrm{l} / \mathrm{min} \quad 6 \mathrm{l} / \mathrm{min} \quad 7 \mathrm{l} / \mathrm{min} \quad 10 \mathrm{l} / \mathrm{min} \quad 15 \mathrm{l} / \mathrm{min}$}

Seguiu-se, primeiramente, a comparação dos dados entre si. Tentamos concluir, a partir dos valores das vazões, quem consumia mais água. Após algumas análises foi percebido que não era possível correlacionar esses dados com os valores das contas de água, pois não havia uma relação do tipo: quanto maior o valor da vazão, maior será o consumo registrado na conta. Discutimos que a relação vazão/consumo total de água talvez não fosse razoável, pois a água consumida na residência ocorre em diversas frentes além dos banhos, como torneiras, máquinas de lavar, etc. No entanto, alunos justificaram a correlação pelo fato de que alguns elementos de suas famílias ficavam muito tempo no banho. Por outro lado, surgiram outras posições de alunos que acreditavam que a lavagem de roupa consumia mais água. Questionamos, então, que talvez a água gasta no banho não correspondesse a maior parte do consumo. 
O valor de $15 \mathrm{l} / \mathrm{min}$, acima mencionado, destacava-se dos demais, pois os demais valores conseguidos situavam-se entre 4 e 8 litros de água por minuto. A peculiaridade em questão é que na residência da aluna havia um chuveiro a gás. Para garantir o real significado da quantidade de água consumida expressa por tal vazão lembrei-os que os galões de água têm a capacidade de 20 litros. A menos do raciocínio aproximado, os estudantes, inclusive a aluna responsável pela medida em discussão, compreenderam, quantitativamente, o que representava ter a cada minuto 15 litros de água caindo sobre suas cabeças. Em resumo, os números ganharam maior significado e entenderam que era muita água!

Com o objetivo de determinar o quanto de água era gasto em banhos pelas famílias, percebi que precisávamos de mais dados para prosseguir com as análises. Sugeri então a eles que medissem o tempo de banho de seus familiares durante uma semana típica de uso do chuveiro.

Etapa 2 - Determinação do tempo de banho dos familiares

Na sequência da atividade, em que utilizamos duas aulas para discussão, foi proposto aos alunos que determinassem a quantidade de água direcionada ao banho durante uma semana típica da família, sem que os mesmos soubessem, para que as amostras não ficassem viciadas. As tabelas foram construídas sem recurso computacional e, apesar de alguns haverem feito 5 medições e outros 7 medições (segunda à sexta e segunda a domingo, respectivamente), muitas discussões importantes puderam ser feitas a partir dos resultados coletados. A seguir, a partir dos resultados coletados, mostramos os tempos de banhos de alguns alunos.

\begin{tabular}{|l|l|l|l|l|l|l|l|l|}
\hline \multicolumn{7}{|c|}{ TEMPOS DE BANHO EM MIN. } \\
\hline Aluno & SEG & TER & QUAR & QUIN & SEX & SAB & DOM & VAZÃO EM L/MIN \\
\hline 1 & 15 & 9 & 7 & 11 & 13 & $* * *$ & $* * *$ & 4 \\
\hline 2 & 10 & 25 & 35 & 36 & 28 & $* * *$ & $* * *$ & 5 \\
\hline 3 & 15 & 10 & 14 & 10 & 15 & 15 & 13 & 4 \\
\hline 4 & $* * *$ & $00: 07: 16$ & $00: 10: 07$ & $00: 09: 25$ & $00: 08: 26$ & $* * *$ & $* * *$ & 6 \\
\hline 5 & 20 & 20 & 15 & 18 & 5 & 5 & 7 & 7 \\
\hline 6 & 7 & 7 & 7 & 7 & 7 & 7 & 7 & 10 \\
\hline
\end{tabular}

Tabela 3 Tempos de banhos de alunos do $6^{\circ}$ do E.F. em uma semana típica. OBS: $\left(^{* * *}\right)$ indica que o valor não foi aferido nesse dia 
As atenções voltaram-se para os tempos de banhos dos próprios alunos que imediatamente calcularam quanto de água cada um gastou naquela semana, conforme destacamos a seguir:

1) $15+9+7+11+13=55 \rightarrow 55 \mathrm{~min} \times 4 \mathrm{l} / \mathrm{min} \rightarrow$ Total: 220 litros na semana

2) $10+25+35+36+28=134 \rightarrow 134 \mathrm{~min} \times 5 \mathrm{l} / \mathrm{min} \rightarrow$ Total: 670 litros por semana

3) $13+15+10+14+10+15+15=92 \rightarrow 92 \mathrm{~min} \times 4 \mathrm{l} / \mathrm{min} \rightarrow$ Total: 368 litros na semana

4) $7: 00+10: 00+9: 30+8: 30=35 \rightarrow 35 \mathrm{~min} \times 6 \mathrm{l} / \mathrm{min} \rightarrow$ Total: 210 litros por semana

5) $20+20+15+18+5+5+7=90 \rightarrow 90 \mathrm{~min} \times 7 \mathrm{l} / \mathrm{min} \rightarrow$ Total: 630 litros

6) $7+7+7+7+7=35 \rightarrow 35 \mathrm{~min} \times 10 \mathrm{l} / \mathrm{min} \rightarrow$ Total: 350 litros

Naturalmente, a comparação sobre quem gastava o maior volume de água começou. O primeiro ponto surgiu entre os alunos que fizeram os cálculos 1 e 3 . Este último insistiu em dizer que a comparação entre eles não era justa, pois no seu caso, havia feito 7 medições contra 5. Já o aluno de número 2 não se manifestou porque percebeu que seu valor calculado só aumentaria ao acrescentar alguns dias em suas medições. Esse tipo de discussão, que surgiu em outros grupos de alunos, me fez intervir outra vez. Propus que usassem a média aritmética dos tempos. Expliquei que o valor médio seria um valor representativo da amostra e, para minha frustração, embora fosse pertinente introduzir o conceito de média aritmética, os alunos apenas efetuaram o cálculo mecânico sem qualquer reflexão ou entendimento do conceito. Assim, entendendo que para continuar a análise precisaríamos de outras ferramentas que possibilitassem fazer comparações com porcentagens, sendo isso não pertinente ao $6^{\circ}$ ano, resolvi encerrar o trabalho. Esse mesmo trabalho foi retomado com os alunos no $7^{\circ}$ ano, com a proposição de outras atividades, conforme descrevemos na próxima etapa.

Etapa 3 - Tabela resumo

Nessa etapa (primeira realizada no $7^{\circ}$ ano), que durou aproximadamente 7 aulas, após retomar as discussões, inclusive para que os novos alunos se sentissem à vontade na participação da atividade, sugeri que construíssem outra tabela com mais informações: tempo e consumo médio diário, semanal e mensal; percentual de gasto de água em banho de cada membro da família relativo ao gasto total em banhos, e em relação ao consumo total de água constante na conta emitida pela SABESP (Companhia de Saneamento Básico do Estado de São Paulo). 
Nessa etapa, a abordagem da média aritmética como medida resumo foi mais significativa para os alunos, para além de um simples cálculo. Conforme a tabela do registro dos tempos de banho dos familiares (Etapa 2), alguns alunos calcularam o volume de água gasto nos respectivos períodos. Perguntados se, a partir desse número, poderiam calcular o volume de água mensal demandado em seus banhos, as respostas foram as mais diversas:

- multiplico por 4 (no caso daquele que considerou 7 medições).

- um mês tem 4 ou 5 semanas?

- o mês tem 30 ou 31 dias?

O caso é que todos eles estavam preocupados em fazer uma análise do consumo mensal, ou seja, saber o que ocorre em 30 dias de consumo de água a partir de suas medições. Logo perceberam uma complicação, pois nenhum múltiplo de 7 é uma boa aproximação de 30 e, por algum motivo, nenhum daqueles que efetuaram 5 medições optou ou compartilhou com o restante da sala a possibilidade de multiplicar o 5 por 6 . Na tentativa de entender seus motivos, levantei a hipótese de que todos buscaram estimar o gasto mensal a partir do gasto semanal.

Nesse momento, fiz uma breve pausa na atividade para explicar o conceito de média aritmética utilizando as idades dos alunos. Na lousa, registrei a idade de todos (a maioria com 11 ou 12 anos de idade) e, sem entrar no mérito dos cálculos, perguntei se o valor que obtive, que chamamos de média aritmética, resumia aquele conjunto de dados ali presente no quadro. Mais especificamente, perguntei se eu poderia afirmar que, em média, os alunos daquele $7^{\circ}$ ano tinham a idade 11,3 anos, como calculado. A maioria disse que sim (alguns não se manifestaram, mas acompanharam a discussão). Resolvi inserir minha idade no conjunto de dados e pedi que recalculassem a média aritmética das pessoas daquela da sala. O novo número $(12,4)$ extrapolou os valores individuais das idades dos alunos e, portanto, logo foi refutado como valor que pudesse representar, em geral, as verdadeiras idades dos mesmos. Assim, após algumas discussões, creio ter introduzido o conceito de média aritmética como medida resumo de um conjunto de dados, tanto mais representativa quanto mais homogêneos forem os dados.

De volta à atividade, o cálculo da média dos tempos de banho coletados ao longo de 5 ou 7 dias forneceu uma medida resumo do tempo médio diário característico do consumo de cada família. Com esse resultado, puderam construir as tabelas, das quais trazemos alguns exemplos. 
Aluno 1

\begin{tabular}{|c|c|c|c|c|c|}
\hline & \multicolumn{5}{|c|}{ Consumo de água uos familiares } \\
\hline & Segunda & Terça & Quarta & Quinta & Sexta \\
\hline Pai & $7 \mathrm{~min}$ & $8 \mathrm{~min}$ & $7 \mathrm{~min}$ & $7 \mathrm{~min}$ & $6 \min$ \\
\hline Mãe & $8 \mathrm{~min}$ & $7 \mathrm{~min}$ & $10 \mathrm{~min}$ & $8 \mathrm{~min}$ & $11 \mathrm{~min}$ \\
\hline Irmã & $10 \mathrm{~min}$ & $9 \mathrm{~min}$ & $8 \mathrm{~min}$ & $15 \mathrm{~min}$ & $7 \mathrm{~min}$ \\
\hline Aluno & $15 \mathrm{~min}$ & $9 \mathrm{~min}$ & $7 \mathrm{~min}$ & $11 \mathrm{~min}$ & $13 \mathrm{~min}$ \\
\hline \multicolumn{6}{|c|}{ Vazão: $41 / \mathrm{min}$} \\
\hline \multicolumn{6}{|c|}{ Tempos de banho de familiares de um aluno do $\sigma^{*}$ ano do $E$. F. } \\
\hline
\end{tabular}

\begin{tabular}{|l|l|l|l|l|l|}
\hline Familia & $\begin{array}{l}\text { Consumo médio diário/ } \\
\text { Tempo médio diário }\end{array}$ & $\begin{array}{l}\text { Consumo } \\
\text { Semanal }\end{array}$ & $\begin{array}{l}\text { Consumo } \\
\text { Mensal }\end{array}$ & $\begin{array}{l}\% \text { em relação } \\
\text { relação à } \\
\text { familia }\end{array}$ & $\begin{array}{l}\% \text { em registrado } \\
\text { (SABESP) }\end{array}$ \\
\hline Pai & Consumo: 28 Tempo: 7 & 140 & 840 & $18 \%$ & $9 \%$ \\
\hline Mãe & Consumo: 34.4 Tempo: 8.6 & 172 & 1032 & $22 \%$ & $11 \%$ \\
\hline Irmã & Consumo: 39,2 Tempo: 9,8 & 196 & 1176 & $25 \%$ & $13 \%$ \\
\hline Aluno 1 & Consumo: 55 Tempo: 13,75 & 275 & 1650 & $35 \%$ & $22 \%$ \\
\hline Total & $\begin{array}{l}\text { Consumo: } 156.6 \\
\text { Tempo: } 39\end{array}$ & 783 & 4698 & $100 \%$ & $55 \%$ \\
\hline \multicolumn{2}{rl}{ Resumo comparativo de gasto por familiar e em relação ao consumo total da familia do aluno 1 } \\
\hline
\end{tabular}

Tabela 4 Tempos de banhos e Resumo comparativo de gasto de familiares do aluno 1

Aluno 2

\begin{tabular}{|c|c|c|c|c|c|}
\hline \multicolumn{6}{|c|}{ Consumo de água dos Familiares } \\
\hline $51 / \mathrm{min}$ & Segunda & Terça & Quarta & Quinta & Sexta \\
\hline Măe & $10 \mathrm{~min}$ & $15 \mathrm{~min}$ & $25 \mathrm{~min}$ & $22 \mathrm{~min}$ & $19 \mathrm{~min}$ \\
\hline Aluno & $10 \mathrm{~min}$ & $25 \mathrm{~min}$ & $35 \mathrm{~min}$ & $36 \mathrm{~min}$ & $28 \mathrm{~min}$ \\
\hline Padrast & $30 \mathrm{~min}$ & $25 \mathrm{~min}$ & $15 \mathrm{~min}$ & $18 \mathrm{~min}$ & $20 \mathrm{~min}$ \\
\hline
\end{tabular}

\begin{tabular}{|l|l|l|l|l|l|}
\hline Familia & $\begin{array}{l}\text { Consumo Médio/ } \\
\text { Tempo Médio }\end{array}$ & $\begin{array}{l}\text { Consumo } \\
\text { Semanal }\end{array}$ & $\begin{array}{l}\text { Consumo } \\
\text { Mensal }\end{array}$ & $\begin{array}{l}\% \text { em relação a } \\
\text { familia }\end{array}$ & $\begin{array}{l}\% \text { em relação ao } \\
\text { consumo registrado }\end{array}$ \\
\hline Mãe & $\begin{array}{l}\text { Consumo: } 91,0 \\
\text { Tempo: } 18,2\end{array}$ & 455 & 2730 & $27 \%$ & $\ldots * *$ \\
\hline Aluno 2 & $\begin{array}{l}\text { Consumo: } 144 \\
\text { Tempo: } 28,8\end{array}$ & 720 & 4320 & $42 \%$ & $* * *$ \\
\hline Padrasto & $\begin{array}{l}\text { Consumo: } 108 \\
\text { Tempo: } 21,6\end{array}$ & 540 & 3240 & $31 \%$ & $\ldots *$ \\
\hline Total & $\begin{array}{l}\text { Consumo: } 343 \\
\text { Tempo: } 68.6\end{array}$ & 1715 & 10290 & $100 \%$ & $\ldots * *$ \\
\hline
\end{tabular}

Tabela 5 Tempos de banhos e Resumo comparativo de gasto de familiares do aluno 2 
Aluno 3

$41 / \mathrm{min}$ Consumo de água dos familiares

$\begin{array}{llllllll} & \text { Domingo Segunda } & \text { Terça } & \text { Quarta } & \text { Quinta } & \text { Sexta } & \text { Sabado } \\ \text { Pai } & 10 \mathrm{~min} & 12 \mathrm{~min} & 10 \mathrm{~min} & 13 \mathrm{~min} & 9 \mathrm{~min} & 10 \mathrm{~min} & 13 \mathrm{~min} \\ \text { Mãe } & 5 \mathrm{~min} & 10 \mathrm{~min} & 10 \mathrm{~min} & 6 \mathrm{~min} & 7 \mathrm{~min} & 10 \mathrm{~min} & 12 \mathrm{~min} \\ \text { Avó } & 7 \mathrm{~min} & 8 \mathrm{~min} & 10 \mathrm{~min} & 5 \mathrm{~min} & 10 \mathrm{~min} & 13 \mathrm{~min} & 14 \mathrm{~min} \\ \text { Aluno } & 13 \mathrm{~min} & 15 \mathrm{~min} & 10 \mathrm{~min} & 14 \mathrm{~min} & 10 \mathrm{~min} & 15 \mathrm{~min} & 15 \mathrm{~min}\end{array}$

Tempos de banho de familiares do aluno 3

\begin{tabular}{|l|l|l|l|l|l|}
\hline Família & $\begin{array}{l}\text { Consumo Médio Diário/ } \\
\text { Tempo Médio Diário }\end{array}$ & $\begin{array}{l}\text { Consumg } \\
\text { Semanal }\end{array}$ & $\begin{array}{l}\% \text { Consumo } \\
\text { Mensal } \\
\text { relação a } \\
\text { familia }\end{array}$ & $\begin{array}{l}\% \text { em relação \&o } \\
\text { registrado Sabı }\end{array}$ \\
\hline Pai & Consumo: 44 Tempo: 11 & 308 & 1232 & $11 \%$ & $10 \%$ \\
\hline Mãe & Consumo:34 Tempo: 8.5 & 238 & 952 & $9 \%$ & $7 \%$ \\
\hline Avó & Consumo: 38 Tempo: 9.5 & 266 & 1064 & $10 \%$ & $8 \%$ \\
\hline Aluno 3 & Consumo: 52.8 Tempo:13.2 & 369.6 & 4256 & $40 \%$ & $22 \%$ \\
\hline Total & Consumo: 211.6 Tempo: 42.2 & 1481.2 & 10368 & $100 \%$ & $47 \%$ \\
\hline
\end{tabular}

Tabela 6 Tempos de banhos e Resumo comparativo de gasto de familiares do aluno 3

Aluno 4

\begin{tabular}{|l|l|l|l|l|}
\hline Familia & Terça & Quarta & Quinta & Sexta \\
\hline Mãe & $00: 07: 30$ & $00: 08: 06$ & $00: 06: 02$ & $00: 07: 26$ \\
\hline Pai & $00: 08: 15$ & $00: 10: 12$ & $00: 05: 36$ & $00: 09: 05$ \\
\hline Irmã & $00: 05: 29$ & $00: 06: 32$ & $00: 05: 04$ & $00: 09: 15$ \\
\hline Aluno 4 & $00: 07: 16$ & $00: 10: 07$ & $00: 09: 25$ & $00: 08: 26$ \\
\hline Vazão: 61/min & & & & \\
\hline
\end{tabular}

\begin{tabular}{|l|l|l|l|l|l|}
\hline & $\begin{array}{l}\text { Tempo } \\
\text { médio/consumo }\end{array}$ & $\begin{array}{l}\text { Consumo } \\
\text { semanal }\end{array}$ & Consumo mensal & $\begin{array}{l}\% \text { em } \\
\text { relação à } \\
\text { familia }\end{array}$ & $\begin{array}{l}\% \text { consumo } \\
\text { total da casa } \\
\text { (Sabesp) }\end{array}$ \\
\hline Mãe & $7 / 42$ & 210 & 1.260 & $(24 \%) 0,24$ & \\
\hline Pai & $8 / 48$ & 240 & 1.440 & $(28 \%) 0,28$ & $11 \%$ \\
\hline Irmã & $6 / 36$ & 180 & 1.080 & $(21 \%) 0,21$ & $6 \%$ \\
\hline Aluno 4 & $8 / 48$ & 240 & 1.440 & $(24 \%) 0,25$ & $11 \%$ \\
\hline TOTAL & $29 / 174$ & 870 & 5.220 & $(100 \%) 1,00$ & $34 \%$ \\
\hline
\end{tabular}

Tabela 7 Tempos de banhos e Resumo comparativo de gasto de familiares do aluno 4 
Aluno 5

\begin{tabular}{|l|l|l|l|l|l|l|l|}
\hline $7 \mathrm{l} / \mathrm{min}$ & & Consumo & dos & Familiares & & & \\
\hline Semana & SEG & TER & QUA & QUI & SEX & SAB & DOM \\
\hline MAE & $10 \mathrm{mim}$ & $20 \mathrm{mim}$ & $7 \mathrm{mim}$ & $9 \mathrm{mim}$ & $12 \mathrm{mim}$ & $15 \mathrm{mim}$ & $8 \mathrm{mim}$ \\
\hline TIO & $5 \mathrm{mim}$ & $4 \mathrm{mim}$ & $8 \mathrm{mim}$ & $7 \mathrm{mim}$ & $6 \mathrm{mim}$ & $10 \mathrm{mim}$ & $3 \mathrm{mim}$ \\
\hline VÓ & $10 \mathrm{mim}$ & $10 \mathrm{mim}$ & $15 \mathrm{mim}$ & $20 \mathrm{mim}$ & $25 \mathrm{mim}$ & $17 \mathrm{mim}$ & $12 \mathrm{mim}$ \\
\hline Aluno 5 & $20 \mathrm{mim}$ & $20 \mathrm{mim}$ & 15 mim & $18 \mathrm{mim}$ & $5 \mathrm{mim}$ & $5 \mathrm{mim}$ & $7 \mathrm{mim}$ \\
\hline
\end{tabular}

\begin{tabular}{|l|l|l|l|l|l|}
\hline Familia & $\begin{array}{l}\text { Tempo médio/média } \\
\text { diária }\end{array}$ & Semanal & Mensal & $(\%)$ familia & (\%)sabesp \\
\hline Mae & $11.6 \mathrm{~min} / 81$ litros & 405 & 2430 & 25 & $* * *$ \\
\hline Tio & $6 \mathrm{~min} / 42$ litros & 210 & 1260 & 13 & $* * *$ \\
\hline Avo & $15.5 \mathrm{~min} / 109$ litros & 545 & 3270 & 34 & $* * *$ \\
\hline Aluno 5 & $13 \mathrm{~min} / 91$ litros & 455 & 2730 & 28 & $* * *$ \\
\hline Total & $46.1 / 323$ litros & 1615 & 9690 & 100 & $* * *$ \\
\hline
\end{tabular}

Tabela 8 Tempos de banhos e Resumo comparativo de gasto de familiares do aluno 5

Aluno 6

\begin{tabular}{|l|l|l|l|l|l|}
\hline $10 \mathrm{l} / \mathrm{min}$ & \multicolumn{5}{|c|}{ Consumo de água dos familiares } \\
\hline Familia & Segunda & Terça & Quarta & Quinta & Sexta \\
\hline Pai & $7 \mathrm{~min}$ & $7 \mathrm{~min}$ & $7 \mathrm{~min}$ & $7 \mathrm{~min}$ & $7 \mathrm{~min}$ \\
\hline Mãe & $7 \mathrm{~min}$ & $7 \mathrm{~min}$ & $7 \mathrm{~min}$ & $7 \mathrm{~min}$ & $7 \mathrm{~min}$ \\
\hline Aluno 6 & $7 \mathrm{~min}$ & $7 \mathrm{~min}$ & $7 \mathrm{~min}$ & $7 \mathrm{~min}$ & $7 \mathrm{~min}$ \\
\hline Avô & $7 \mathrm{~min}$ & $7 \mathrm{~min}$ & $7 \mathrm{~min}$ & $7 \mathrm{~min}$ & $7 \mathrm{~min}$ \\
\hline Avó & $7 \mathrm{~min}$ & $7 \mathrm{~min}$ & $7 \mathrm{~min}$ & $7 \mathrm{~min}$ & $7 \mathrm{~min}$ \\
\hline
\end{tabular}

\begin{tabular}{|l|l|l|l|l|l|}
\hline Família & $\begin{array}{l}\text { Tempo } \\
\text { médio/consumo médio }\end{array}$ & $\begin{array}{l}\text { Consumo } \\
\text { semanal }\end{array}$ & $\begin{array}{l}\text { Consumo } \\
\text { mensal }\end{array}$ & $\begin{array}{l}\% \\
\text { relação a } \\
\text { familia }\end{array}$ & $\begin{array}{l}\% \text { consumo } \\
\text { total da casa } \\
\text { (SABESP) }\end{array}$ \\
\hline Pai & $4,9 / 49$ & 343 & 10290 & $20 \%$ & $* * *$ \\
\hline Mãe & $4,9 / 49$ & 343 & 10290 & $20 \%$ & $* * *$ \\
\hline Aluno 6 & $4,9 / 49$ & 343 & 10290 & $20 \%$ & $* * *$ \\
\hline Avô & $4,9 / 49$ & 343 & 10290 & $20 \%$ & $* * *$ \\
\hline Avó & $4,9 / 49$ & 343 & 10290 & $20 \%$ & $* * *$ \\
\hline
\end{tabular}

Tabela 9 Tempos de banhos e Resumo comparativo de gasto de familiares do aluno 6 
O fato de que alguns alunos morarem em prédios sem água individualizada e, portanto, não terem acesso a seus respectivos consumos, implicou no não preenchimento da última coluna. Apesar disso, dentro dos grupos, os mesmos alunos acompanharam as discussões que ali ocorreram. Eram comuns frases do tipo:

- Nossa! 70\% de minha conta ocorre no banho, mas a vazão é menor do que o outro que compromete $60 \%$ da conta!

- Será que posso resolver isso reduzindo a metade do meu tempo de banho? E se eu diminuir a vazão do chuveiro?

Os alunos 1 e 3, da discussão anterior, tiveram a oportunidade de concluir quem efetivamente gasta mais água. Usando os tempos médios diários, o segundo aluno constatou que de fato seu consumo era maior.

O fato mais importante nessa etapa, em minha opinião, foi o deslocamento da atenção dos alunos para a quantidade de água que se gasta no banho e o quanto isso compromete a conta de água. As disputas com outros colegas passaram a ser uma reflexão sobre o como eles mesmos podem atuar para combater o desperdício.

Ainda assim, a pergunta do início do problema (“Seu consumo é alto ou baixo?”) não havia sido respondida. Em razão de estarem confusos sobre quais critérios utilizarem para respondê-la, além das comparações de consumos entre os colegas, pedi que fizessem pesquisas na internet, que talvez os ajudassem a responder às questões.

Etapa 4. Comparação entre os consumos residenciais de água e de outros setores da sociedade

Nesta etapa (segunda tarefa realizada no $7^{\circ}$ ano), que durou 5 aulas, sugeri que buscassem responder às seguintes questões: qual o volume de água que a Organização Mundial de Saúde (OMS) recomenda como mínimo necessário para o ser humano viver? Qual o destino de toda a água tratada pela SABESP, ou seja, especificamente, qual o volume de água demandado pelos domicílios, pela indústria e pela agricultura? Além disso, os alunos reconstruíram suas tabelas utilizando planilha eletrônica.

Como resposta à primeira pergunta, constataram que a OMS indica ser suficiente 110 litros para cada ser humano suprir suas necessidades diárias levando a muitos dos alunos constatarem apenas que seu consumo diário em banhos estava dentro desse mesmo limite. Com relação à segunda questão, a pesquisa mostrou que os volumes demandados em cada setor são: consumo residencial - 10\%, consumo industrial - 20\%, e consumo agrícola $-70 \%$. Diante disso, alguns alunos efetuaram cálculos aproximados a partir das contas de água da 
residência e constataram que seu consumo individual estava dentro do limite da OMS. As respostas dadas à segunda pergunta suscitaram os seguintes questionamentos: se o maior volume é direcionado para indústria e agricultura, por que o governo está mandando eu economizar? Por que a indústria usa tanta água, se boa parte do que ela produz é seco? Esses questionamentos nos levaram à próxima etapa.

Etapa 5 - Demanda de água pela indústria para a produção de alguns bens de consumos

Nesta etapa (terceira realizada nos $7^{\circ}$ anos), que durou duas aulas, propus que pesquisassem na internet quanto de água era despendido na produção de alguns bens de consumo como: $1 \mathrm{~kg}$ de carne, 1 computador, $1 \mathrm{~kg}$ de papel e outros bens que considerassem importantes. Novamente, sujeitas a algumas variações entre os alunos, as respostas foram as seguintes:

$1 \mathrm{~kg}$ de carne: 15.500 litros

1 Computador: 31,5 mil litros

1 folha de papel A4: 10 litros

1 Carro: 144.300 litros

Sem entenderem o porquê do volume de água gasto ser tão alto para, por exemplo, produzir cerveja e papel, recomendei que pesquisassem como são produzidos. Enfim, ficou claro para os estudantes que a cadeia produtiva dos bens tem um papel muito importante no cálculo do volume de água despendido. Entenderam que para a produção de papel, o que demanda mais água é o cultivo de eucaliptos; no caso da carne bovina, a água considerada corresponde a todo o período de engorda dos animais; a cerveja, o cultivo de cevada é o grande responsável por utilização de água (1300 litros por $\mathrm{kg}$ de cevada). Com relação a computador e carro, percebendo a complexidade de suas cadeias produtivas, alguns alunos chegaram até mesmo a pesquisar como se produz as peças de metal ali presentes. Convenceram-se, assim, sobre a real necessidade do uso da água na produção desses bens.

\section{Análise da prática didática desenvolvida com o $7^{\circ}$ ano}

Como atividade voltada ao trabalho em sala de aula de argumentações com Matemática, esse experimento desenvolveu-se dentro de um cenário para investigação em uma realidade (etapas 1 e 2) e, posteriormente, em uma semirrealidade, com seus respectivos paradigmas do exercício (etapas 3 a 5), nos termos da classificação feita por Skovsmose (ver 
página 47). De forma específica, podemos dizer que os alunos vivenciaram, por meio de experimentos com vazão e cálculo de porcentagens, a utilização de razões como grandezas para expressar comparações, quando as medidas das verdadeiras quantidades são inacessíveis ou impróprias para se estabelecerem comparações. Tal fato ficou evidente quando concluíram que o volume de água do banho não poderia ser acessado por medida direta devido à impossibilidade de ser armazenada e também pelo fato de que os volumes indicados em suas contas de água não poderiam ser comparados sem levar em consideração o número de pessoas na residência. Esses dois aspectos, por eles percebidos, validaram a proposta de criar uma unidade comum para balizar a conversa.

Podemos dizer que o trabalho desenvolvido em sala de aula promoveu a interação dialógica entre os membros dessa micro sociedade. O espaço de argumentações e refutações criado com o objetivo de entender e competir sobre quem consumia a menor quantidade de água estabeleceu um debate crítico. Ou seja, nesse ambiente, as ideias propostas ficaram sujeitas à aprovação ou reprovação dos demais, necessitando ser defendidas apenas com o uso de ideias do próprio contexto matemático. Além disso, em alguns momentos da atividade, a apropriação pelos alunos do ferramental matemático e suas aplicações no contexto, permitiu que vislumbrassem a possibilidade real de intervenção em sua realidade próxima, no que se refere à redução do consumo de água familiar. Assim, esse espaço de discussão conjunta com a possibilidade de intervenção social dos estudantes, para nós, caracterizou o exercício de um objetivo da Educação Básica (conforme o Art. 205 da Constituição Federal e o Art., $2^{\circ}$ da LDBEN -1996): o pleno desenvolvimento, o exercício da cidadania e a qualificação para o trabalho. Podemos dizer também que foi um momento onde se proporcionou a vinculação entre a educação escolar, o trabalho e as práticas sociais (DCNGEB, alínea XI, 2010) e um espaço democrático de debates.

Por fim, conforme Dewey (1959), podemos dizer que exercitamos as três funções atribuídas à escola:

1) propusemos um ambiente de aprendizado no qual o educando assimilou conhecimento gradativamente, conforme sua evolução e maturidade;

2) desvinculamos, nesses espaços de argumentações, o ensino de preconceitos e ideologias, criando um ambiente isento e plural, propício para a ação;

3) possibilitamos aos indivíduos vivenciarem questões pertinentes a um ambiente social que ultrapassou as limitações do grupo social em que vivem.

No que se refere ao desenvolvimento do senso crítico, novamente destacamos características próprias de um pensador crítico conforme, já destacamos na página 28 : 
1. Uma atitude de constante de curiosidade intelectual e questionamento;

4. A perspicácia, isto é, a tendência a perceber além do que é dito explicitamente, descobrindo as ideias subentendidas e subjacentes;

5. A consciência pragmática, um reconhecimento e apreciação dos usos práticos da linguagem como meio de realizar objetivos e influir sobre os outros;

6. Uma distinção entre questões de fato, de valor e questões conceituais;

7. A habilidade de penetrar até o cerne de um debate, avaliando a coerência de posições e levantando questões que possam esclarecer a problemática.

$\mathrm{Na}$ atividade que desenvolvemos, acreditamos ter contribuído para o desenvolvimento do senso crítico por meio da consecução dessas cinco características que, dentre outras, Carraher definiu serem fundamentais para caracterizar um pensador crítico.

Buscamos, no desenvolvimento da atividade, estimular o que Carraher definiu como atitude de curiosidade intelectual, pois incentivamos os alunos a responderem questões de tal forma que não se baseassem no senso comum, ou seja, estimulamos o interesse em compreender as questões mais profundamente.

Por meio do ferramental matemático abordado, pudemos fazer com que os alunos percebessem elementos nas afirmações para além daqueles que eram explicitados na mídia sobre a escassez e o uso da água pela população. Entenderam que, apesar de não serem veiculadas informações falsas, havia uma tendência de apenas justificar a prática do rodízio imposta pelo governo, sem dar explicações sobre os reais motivos da falta de água.

De forma indireta, em meio às discussões propusemos que os alunos fizessem uma distinção entre questões de fato e questões conceituais. Nesse ponto, em várias etapas do trabalho, perceberam que a validade de argumentos só poderia ser averiguada a partir de uma base comum de conhecimentos, ou com o estabelecimento de parâmetros aceitos por todos.

Finalmente, por meio de experimentações, cálculos, pesquisas, questionamentos, argumentações e refutações, criamos um ambiente que permitiu aos alunos a possibilidade de aprofundar as questões envolvidas no debate de maneira mais objetiva e embasada. Destacamos que a análise efetuada pelos alunos permitiu uma resposta individual sobre o consumo dos recursos hídricos. Dessa forma, como conclusão prévia deste parágrafo, podemos afirmar que propor aos alunos esse tipo de atividades, que visem, nos termos de Skovsmose, combater a Ideologia da Certeza e o Poder Formatador da Matemática, teve como consequência o desenvolvimento nos indivíduos do poder de decidir sobre quão alto, ou baixo, é seu consumo de água ampliando suas capacidades de pensamento crítico. 
Desse modo, o espaço de argumentações e refutações criado em sala de aula possibilitou um exercício de cidadania e uma atuação sobre questões de interesse social. Reescrevendo o que já abordamos na página 11 desta dissertação, durante o desenvolvimento da sequência didática as atividades propostas buscaram contribuir para propiciar o desenvolvimento do educando na direção de assegurar-lhe a formação para o exercício da cidadania; meios para atuar na sociedade observando princípios éticos e valores democráticos; maior compreensão do espaço social onde vive; a preparação para o trabalho e a cidadania; o aprimoramento do educando como pessoa humana. Ainda mais, no que compete ao foco desta dissertação, contribuímos para a formação de atitudes e valores como instrumentos para o exercício do pensamento crítico e da formação de critérios para uma análise crítica de uma determinada problemática social importante. 


\section{Considerações finais}

Nestas considerações finais buscamos fazer uma análise sobre o que conseguimos avançar com esta dissertação no aprofundamento da compreensão sobre as questões motivadoras e relativamente aos objetivos colocados na sua introdução.

\section{QUESTÕES MOTIVADORAS}

1) Tendo em vista que o senso crítico é uma capacidade importante na atuação consciente dos cidadãos na sociedade, surgem as questões: o que é senso crítico? Que papel o ensino de Matemática na Educação Básica pode representar no desenvolvimento de senso crítico e da capacidade de argumentação dos educandos?

2) Tendo em vista que o trabalho investigativo do matemático profissional se caracteriza por resolver problemas, sendo essencial o levantamento de hipóteses, questionamentos, análises de erros, argumentações e validações, a pergunta que se segue é: como essa metodologia, utilizada na construção dessa Ciência, pode ser empregada em sala de aula do Ensino Fundamental, no sentido de contribuir para o desenvolvimento do senso crítico e das habilidades típicas do trabalho do matemático profissional listadas?

3) Tendo em vista que os conhecimentos matemáticos são necessários para muitas tomadas de decisões no cotidiano e nas diversas práticas sociais, como favorecer, em sala de aula de Matemática do Ensino Fundamental, o desenvolvimento das capacidades de argumentar e validar conclusões na articulação daquela ciência com questões sociais relevantes no exercício da cidadania?

\section{OBJETIVOS}

1) Fazer um levantamento sobre o que a legislação e autores definem sobre a formação integral do educando.

2) Pesquisar embasamento teórico adequado que possibilite um aprofundamento tanto sobre os significados de senso crítico e de argumentação quanto sobre reflexões sobre práticas educacionais voltadas ao desenvolvimento de tais capacidades em sala de aula de Matemática na Educação Básica. Particularmente, estudar os trabalhos de Ole Skovsmose, Nicolas Balacheff e Pierre Marie van Hiele. 
3) Elaborar propostas de atividades, aplicar com nossos alunos de $6^{\circ}$ e de $7^{\circ}$ anos da Escola Estadual Domingos Mignoni e analisar as sequências didáticas desenvolvidas, com vistas a investigar e aprofundar a reflexão sobre as questões 2 e 3 .

No desenvolvimento deste trabalho, procuramos entender que tipos de propostas de atividades pedagógicas em Matemática podem favorecer o desenvolvimento do senso crítico. Concluímos que essa modalidade de pensamento pode ser construída pelo educando durante a Educação Básica, à medida que forem trabalhadas em sala de aula situações de aprendizagem que estimulem sua capacidade de apreciar a existência de diversas relações que podem ser feitas em torno do tema em estudo. Para tanto, além de dominar conhecimento específico, conforme destacamos anteriormente (Cap. II.4), os processos de análise, síntese, conceptualização e avaliação de informações revelam-se de muita importância para o aprendizado e evolução das concepções do educando sobre o tema em questão. O exercício dessas capacidades, manifestadas por meio de argumentações, foi importante para o aprendizado significativo dos estudantes tanto na atividade em Geometria quanto naquela sobre a crise hídrica. Isso porque pudemos perceber um aprimoramento da qualidade de seus julgamentos quando confrontados com as situações-problema propostas. Nesses casos, a transposição do pensamento ingênuo ao crítico ficou nítida quando os alunos teceram julgamentos, conclusões ou consequências (sobre o assunto em discussão) de forma cada vez mais clara, precisa, consistente, relevante e imparcial.

A prática argumentativa em sala de aula nos auxiliou na construção e validação de conhecimentos matemáticos e também permitiu emitir julgamentos sobre afirmações em outros espaços que façam uso desses conhecimentos. Para entendermos os diversos contextos em que os argumentos matemáticos estão presentes, discutimos o seu papel em três deles: na prática de elaboração de demonstrações do matemático profissional; na prática de construção de provas matemáticas em sala de aula; e em termos da apropriação de linguagem e conhecimentos matemáticos como suporte para argumentações com Matemática para uma atuação na sociedade.

Em diversos contextos de práticas sociais existe a necessidade de se decidir sobre a veracidade ou falsidade de afirmações nas quais são utilizados conceitos e ferramentas matemáticos para dar força ao caráter de verdade do argumento. Trata-se de afirmações cuja validação requer conhecimento matemático, análise de relações lógicas, raciocínios indutivos ou estatísticos para a tomada de decisão sobre seu caráter de verdade. Em muitos casos, o exame das relações lógicas não é suficiente para buscar construir uma validação, 
sendo essencial levar em conta também o contexto em que a afirmação está inserida e o conhecimento de ideias e linguagem matemáticas, conforme verificamos em nosso segundo experimento didático.

Tendo em vista nossas questões motivadoras 2 e 3, foi-nos útil definir as noções de Argumentações em Matemática e Argumentações com Matemática, para diferenciar argumentos que têm como objetivo validar afirmações pertinentes aos contextos puramente matemáticos daqueles que validam asserções pertinentes a contextos que extrapolam a Matemática pura. Nos experimentos aqui descritos e analisados abordamos essas duas categorias de argumentos matemáticos. A distinção entre elas faz também sentido à luz de Duval (1992-1993, apud D'AMORE, 2007, p. 360), que entende ser distinta a habilidade de argumentar em geral da habilidade para realizar deduções matemáticas. Ou seja, a transposição de uma habilidade para outra não é automática. Outro ponto que nos auxiliou a diferenciar os dois tipos de discurso foi a proposta de Skovsmose (2014, p. 54), relativa à criação de cenários de investigação - seis ambientes de investigação importantes de serem observados no ensino e aprendizagem de Matemática. Dessa forma, um trabalho envolvendo argumentações em/com Matemática, juntamente com os ambientes de investigação, tornase mais eficiente no sentido de contribuir para a formação integral do educando.

$\mathrm{Na}$ primeira sequência didática, as discussões em grupo e os debates coletivos estimularam os alunos a expressar ideias (corretas ou não) e chegar a consensos sobre a validade do resultado sobre a soma dos ângulos de um triângulo, inclusive utilizando linguagem apropriada da Geometria. Na segunda sequência construída no interior do cenário da crise hídrica, a partir do questionamento sobre o consumo de água das famílias, o desenvolvimento da sequência didática propiciou discussões que permitiram a apreciação (ou entendimento) cada vez mais global da situação proposta, envolvendo questões sobre consumo, desperdício e responsabilidades individuais e coletivas sobre a preservação do bem hídrico. Além do protagonismo dos alunos na construção dos conhecimentos e da participação do professor como mediador, cabe ressaltar a presença dos dois tipos de argumentações nessas últimas atividades: argumentações em Matemática e com Matemática. Como vimos a primeira era intrínseca à Geometria e o discurso dos alunos envolveu somente elementos próprios a essa Ciência; na segunda outros elementos de discurso, além daquele próprio à construção da Matemática, tiveram de ser mobilizados pelos alunos, como na comparação de percentuais envolvendo consumo de água para o banho e o gasto despendido pela família, onde, por exemplo, necessitaram considerar número de membros das famílias para suas conclusões. 
Baseados nas características gerais do pensando crítico, descritas por Carraher (ver p. 28), analisamos ${ }^{1}$ as atividades e pudemos notar que várias delas foram mobilizadas. Nesse sentido, avaliamos que os trabalhos desenvolvidos com os estudantes representaram oportunidades para o desenvolvimento de pensamento crítico contribuindo, portanto, para a formação integral dos estudantes. Haja vista que, no mundo atual, cada vez mais o indivíduo necessita tomar decisões e solucionar problemas complexos, requerendo dos educandos que aumentem a quantidade e a qualidade dos significados daquilo que compreendem e conseguem expressar. Segundo Sezer (2008, apud UDI, 2011), tal fato requer do cidadão imerso na Era da Informação não somente que aprenda a construir seu conhecimento como também que desenvolva habilidades de pensamentos superiores, como o pensamento crítico. Segundo Udi (2011), essa modalidade de pensamento a ser desenvolvida durante a Educação Básica, favorece uma atuação consciente do educando em sua realidade próxima, inclusive mobilizando seus conhecimentos matemáticos.

No que diz respeito às argumentações em Matemática, Van Hiele, ao propor os níveis de desenvolvimento do pensamento geométrico, mostra-nos que os aprendizados de tópicos de Geometria seguem níveis sequenciais e Balacheff (1988), por exemplo, ao classificar os tipos de provas pragmáticas, mostra-nos a possibilidade de fornecer tarefas de maneira que o aluno possa evoluir em suas concepções, passando da produção de provas do tipo empirismo ingênuo ao entendimento e produção de provas do tipo conceitual. Balacheff (1987) mostra ainda que um trabalho com argumentações e refutações em sala de aula é fundamental para que haja essa evolução. Por exemplo, discutimos no capítulo V como uma atividade de produção de provas pragmáticas (empirismo ingênuo e experimento crucial) e conceituais (exemplo genérico e experimento reflexivo) auxilia o aluno na transição dos níveis de Van Hiele, do nível 0 (visualização) ao nível 2 (dedução informal) passando pelo nível 1 (análise). A relação entre os trabalhos dos dois autores tornou-se bastante frutífera para o nosso entendimento sobre o desenvolvimento do pensamento crítico. Ambos os trabalhos, de Balacheff $(1987,1988)$ e Van Hiele (Crowley, 1994), pressupõem a evolução das concepções dos educandos no sentido de fazê-los terem uma compreensão global da situação. Assim, a capacidade de argumentar, segundo os autores, está condicionada à quantidade de relações que o indivíduo pode fazer dentro da Matemática para expressar suas ideias e sustentar suas conclusões. Portanto, essa evolução das concepções do aluno pode

\footnotetext{
${ }^{1}$ Ver pp.91-92, para a análise da primeira sequência didática e pp.115-116 para a da segunda.
} 
conduzir ao aprendizado, ou, nos termos de Paulo Freire, pode concorrer para o desenvolvimento do pensar certo.

A apropriação dos diversos tipos de raciocínios matemáticos - indutivo, lógicodedutivo, não determinístico e visão geométrico-espacial - que defendemos que sejam trabalhados em sala de aula, habilita melhor o estudante a decidir por critérios para a análise da validade de afirmações. A partir de Carraher (2011), Lipmam (2014) e Silva (2000), os critérios adotados pelos interlocutores são fundamentais para o julgamento de um argumento e devem ser utilizados à luz de sua pertinência ao tema em questão. Assim, examinar uma afirmação do ponto de vista das ferramentas da Lógica pode ser interessante, dado que o raciocínio lógico tem um caráter geral e está presente em todas as áreas do conhecimento. Porém, em um contexto de afirmações ou argumentações construídas com o uso de linguagem matemática como, por exemplo, porcentagens ou proporções, em geral outros critérios são necessários para a análise do seu caráter de verdade. Corroborando esses fatos podemos citar a argumentação construída pelos alunos para concluir se o gasto individual de suas famílias com o consumo de água era alto ou baixo. Para que esse encadeamento argumentativo ocorresse, ferramentas de outras áreas do conhecimento necessitaram ser invocadas, como o estatístico e o pertinente ao significado da linguagem das razões e proporções. Em muitas situações da vida em sociedade há a necessidade de fornecer suporte para as conclusões, de modo a garantir, de forma bem embasada, a veracidade daquilo que se afirma. É o que ocorre, por exemplo, em contextos científicos ou jurídicos. Nesses casos, o mero encadeamento de afirmações por meio da utilização do raciocínio lógico não é suficiente para se estabelecer o veredito. Nos exemplos citados antes, há a necessidade de se fazer uso de experimentos comprobatórios ou de provas materiais e leis vigentes.

Assim, pensando que os usos de linguagem simbólica e de noções básicas de Matemática se fazem presentes também em comunicações cotidianas, podemos dizer que o desenvolvimento da capacidade de emitir e avaliar argumentos nas mais diversas situações de práticas sociais se potencializa com o domínio de diversos tipos de raciocínios matemáticos presentes nos mais variados contextos. Corrobora esse entendimento o fato de Skovsmose, por exemplo, propor seis ambientes de aprendizagem para o desenvolvimento de conteúdos matemáticos em sala de aula. $\mathrm{O}$ autor propõe que as abordagens se deem em aulas envolvendo tanto o paradigma do exercício como os cenários para investigação, articulados com as três referências: Matemática Pura, Semirrealidade e Realidade. Segundo ele, tal estratégia de ensino pode garantir o aprendizado da competência de analisar e avaliar criticamente como a Matemática está presente nas diversas práticas sociais; influenciar o 
desenvolvimento cultural, tecnológico e político da sociedade; e valorizar os processos que permitem ao educando o aprendizado mais eficiente de conceitos e ideias matemáticas (Skovsmose, 2014, pp. 65-74)

Em linhas gerais, a adoção do diálogo baseado em argumentações em sala de aula, apoiadas no ambiente de aprendizagem que articula um cenário para investigação com a Realidade, permitiu-nos a construção de resultados matemáticos e a verificação da validade de afirmações em contextos externos à Matemática. Por exemplo, nas sequências didáticas exercitamos a construção do conceito de altura de triângulo e o de vazão, privilegiando a utilização de outros tipos de raciocínios (indutivo e visão geométrico-espacial). Estimulamos também a resolução de problemas não apenas restritos ao campo numérico (por exemplo, como determinar o segmento que identifica a altura de um triângulo). Para analisar as respostas sobre a pergunta “quem gastou mais água?", no segundo experimento, também utilizamos o raciocínio não determinístico, próprio da Estatística e Probabilidade. Tudo isso ocorreu por meio do estabelecimento de um debate crítico em que foram estimuladas e prevaleceram as argumentações justificadas dos estudantes.

No contexto da Geometria focamos as argumentações em Matemática e, no contexto das medidas intensivas (dadas por razões), as argumentações com Matemática. No primeiro caso, a atividade didática envolveu a validação de um resultado geométrico e, no segundo caso, abordamos questão relativa a um tema social concreto, atual e relevante no momento em São Paulo: a escassez de água. Como vimos, nas atividades envolvendo argumentações em Matemática e com Matemática foram trabalhados em sala de aula os quatro tipos de raciocínios matemáticos descritos anteriormente. Entendemos que os contextos de trabalho escolhidos e os objetos matemáticos envolvidos na discussão determinaram o tipo de inferência ou o tipo de raciocínio a ser utilizado para o estabelecimento das conclusões.

Quanto à primeira questão, neste trabalho escolhemos discutir o senso crítico por ser uma modalidade de pensamento que, desenvolvida durante a Educação Básica, pode contribuir para a consecução de elementos importantes entre os que compõem a formação integral do educando prevista nos documentos oficiais brasileiros que tratam da Educação. Como visto no Capítulo II, o pensamento crítico manifesta-se por meio de argumentos. Procuramos aqui investigar como o senso crítico pode ser desenvolvido em aulas de Matemática. Para tanto, e a partir do referencial teórico utilizado, defendemos ser fundamental que argumentações matemáticas sejam trabalhadas com os alunos de Educação Básica. Propusemos também que seja privilegiado o diálogo professor-aluno e aluno-aluno em sala de aula, proporcionando ambientes que envolvam o educando em atividades nas 
quais seja necessária a formulação de argumentações para justificar ou refutar enunciados, afirmações ou resultados nelas envolvidos. Assim concluímos que um ensino de Matemática que observe o desenvolvimento da competência argumentativa pelo aluno durante a Educação Básica pode contribuir efetivamente para a promoção de pensamento crítico e, por conseguinte, sua formação integral.

No que se refere à segunda questão, defendemos que atividades envolvendo provas matemáticas em sala de aula no sentido de Balacheff (1987) podem de fato contribuir para que os estudantes vivenciem situações típicas do trabalho investigativo em Matemática. Para tanto, devem ser conduzidas sob o princípio básico de buscar que aquele tipo de validação tenha a função de desenvolver, no educando, as capacidades tanto de se convencer como de formular argumentos adequados ao convencimento dos demais sobre o caráter de verdade ou falsidade de assertivas. Conforme Balacheff (1987), argumentos que validam resultados matemáticos, como as explicações, provas e demonstrações, dependendo do grupo social a que se destinem, diferem quanto ao nível de rigor, possuindo sempre a mesma função de convencimento sobre o resultado. Podemos dizer que o rigor é um conceito decidido pela própria comunidade dos matemáticos. As provas dotadas de "rigor formal" são definidas no âmbito da Lógica Formal ou Matemática (tecnicamente chamadas de deduções formais); enquanto as demonstrações aceitas pelos matemáticos profissionais, mesmo não atendendo tal nível de formalização em seus registros, são consideradas rigorosas pela comunidade dos pares, em sua prática de validação e comunicação de resultados, na medida em que satisfazem os princípios e regras da Lógica Formal, podendo, se necessário, serem transformadas em deduções formais. Para Balacheff (1987), um trabalho com provas passa por um estágio que é o convencimento do próprio educando sobre a necessidade de se explicitar a verdade da afirmação em caráter geral. Para tanto, o autor afirma que em atividades com argumentos é fundamental o recurso a refutações ou contraexemplos, para que se consiga modificar ou agir sobre as concepções do educando, contribuindo para a evolução de seu aprendizado. Diz ainda ser importante que a experimentação dos alunos com provas matemáticas seja anterior à apresentação de demonstrações, para que, em seus próprios ritmos de aprendizagem, possam desenvolver as habilidades típicas do trabalho investigativo do matemático profissional enumeradas na segunda questão, favorecendo, assim, a sua apropriação de hábitos de raciocínio necessários para o pensador crítico.

$\mathrm{Na}$ realização das sequências didáticas, aspectos práticos e teóricos da Matemática foram igualmente privilegiados, pois, num primeiro momento, os alunos praticaram a investigação em um ambiente de Matemática Pura e, no segundo experimento, trabalharam 
em uma transição entre Semirrealidade e Realidade. A reorganização de pensamento e o consequente desenvolvimento do pensamento crítico foram pontos comuns que ocorreram nas duas atividades desenvolvidas em um espaço de argumentações justificadas. Nesse ambiente, o professor abordou os conteúdos, essencialmente como mediador tanto do conhecimento, quanto das questões propostas, fornecendo, sempre que possível, um dado externo que contrariava suas convicções. Por fim, essa metodologia de investigação nos permitiu estabelecer um ambiente democrático em sala de aula, pois as posições e decisões tomadas pelo grupo foram sempre aquelas que conduziam à resposta de consenso ou à solução do tema em questão. Nesse contexto, os cenários para investigação utilizados na produção das sequências didáticas desenvolvidas estimularam nos alunos os processos de análise e síntese em seus julgamentos, quanto a clareza, precisão, consistência, relevância e imparcialidade de conceitos, conclusões, implicações e consequências.

Enfim, podemos dizer que a metodologia empregada permitiu manter, conforme definiu Skovsmose, uma distância crítica do currículo, que se refere ao distanciamento dos professores e alunos em relação ao conteúdo próprio da disciplina. Assim, os conteúdos foram utilizados como meios para obterem-se novos conhecimentos e não apenas com um fim em si mesmos. Nesses espaços de argumentações justificadas, conseguimos inserir os alunos em um ambiente de aprendizado de Matemática e de formação para cidadania que favoreceu seus desenvolvimentos como pensadores críticos. Assim, nesta dissertação, mostramos que um trabalho baseado em argumentações pode contribuir de maneira efetiva para a validação e construção de conhecimentos matemáticos e para o desenvolvimento do senso crítico dos estudantes. Desse modo, pudemos comprovar a adequação das abordagens adotadas em sala de aula de Matemática aos princípios norteadores para a formação integral dos estudantes constantes dos documentos oficiais relativos à Educação Básica no Brasil. 


\section{Referências Bibliográficas}

ALRø, H.; SKOVSMOSE, O. 2010. Diálogo e Aprendizagem em Educação

Matemática. Tradução: Orlando de A. Figueiredo. 2 Ed. Belo Horizonte: Autêntica Editora, pp 12, 52, 2010.

ANSCOMBRE, JEAN-CLAUDE \& DUCROT, OSWALD. L'argumentation dans la langue. Bruxelles: Mardaga, (Philosophie et Langage), 1983.

BALACHEFF, N. Processus de preuve et situations de validation. Educational

Studies in Mathematics, v. 18, n. 2, pp. 147-176, 1987.

BALACHEFF, N. Aspects of proof in pupils' practice of school mathematics. In: D. Pimm (Ed.): Mathematics, Teachers and Children, pp. 216-235. Londres: Hodder \& Stoughton, 1988.

BRASIL. Constituição (1988). Constituição da República Federativa do Brasil. Brasília, DF: Senado Federal: Centro Gráfico, 1988.

BRASIL (país). MINISTÉRIO DA EDUCAÇÃO, Secretaria de Educação Básica. Lei de Diretrizes e Bases da Educação Nacional. Brasília, 1996. . MINISTÉRIO DA EDUCAÇÃO, Secretaria de Educação Básica.

Diretrizes Curriculares Nacionais da Educação e Diretoria de Currículos e Educação Integral, 2013.

- MINISTÉRIO DA EDUCAÇÃO, Secretaria de Educação Média e Tecnológica. Parâmetros Curriculares Nacionais para o Ensino Médio. Brasília: MEC/SEMTEC, 2000.

CARRAHER, D. W. Senso crítico: do dia-a-dia as ciências humanas. 1 Ed. São Paulo: Pioneira, 2011.

CROWLEY, M. L., O modelo Van Hiele de desenvolvimento do pensamento geométrico, Aprendendo e Ensinando Geometria, São Paulo: Atual, pp. 1-20, 1994.

D’AMORE, B.; Elementos de Didática da Matemática. Tradução: Maria Cristina Bonomi. 1 Ed., São Paulo: Editora Livraria da Física, 2007.

DEMIRA, M., et al. Quadruple Thinking: Critical Thinking. Social and Behavioral Sciences. v 12, 2011, pp. 545-551.

DEWEY, J. Democracia e educação: introdução à filosofia da educação. Trad.

Godofredo Rangel e Anísio Teixeira. 3 ed. São Paulo: Companhia Editora Nacional, 1959. 
DE VILLIERS, M. The role and function of proof. In: De Villiers, M. (ed.), Rethinking Proof with the Geometer's Sketchpad, Key Curriculum Press, 1999, pp. 3-10.

DE VILLIERS, Algumas reflexões sobre a Teoria de Van Hiele. Trad. de Celina A. A. P. Abar. Educ. Matem. Pesq., São Paulo, v.12, n.3, pp. 400-431, 2010.

DINUȚĂ,$N$. The use of critical thinking in teaching geometric concepts in primary school. In: The 6th International Conference Edu World 2014 "Education Facing Contemporary World Issues", 7th - 9th, november, 2014. Procedia - Social and Behavioral Sciences, 788 - 794, 2015

DRUCK, I.F., A Área de Matemática nos Currículos da Educação Básica, In: WEBER, W. (Org.), Ensino Médio em Debate: currículo, avaliação e formação humana integral, (no prelo, a ser publicado em 2017 pela UNB).

DUVAL, R., Semiósis e pensamento humano: registros semióticos e aprendizagens intelectuais. Tradução: Lênio Fernandes Levi e Marisa Rosâni Abreu da Silveira. São Paulo: Editora Livraria da Física.

FERNANDES, J. L. G. Educação e Cidadania em Paulo Freire, Dissertação (Mestrado). Minas Gerais: UEMG, 2011.

FREIRE, P. A. Educação como Prática da Liberdade. 23 Ed. Rio de Janeiro: Paz e Terra, 1999.

FREIRE, P. Pedagogia da autonomia: saberes necessários à prática educativa. $25 \mathrm{Ed}$. São Paulo: Paz e Terra, 1996.

FREIRE, P. Pedagogia do Oprimido. 11 Ed. Rio de Janeiro: Paz e Terra, 2005.

GIANNAKOULIAS, et al. Studying Teachers' Mathematical Argumentation in the Context of Refuting Students' Invalid Claims. The Journal of Mathematical Behavior. v 29, n 3, pp. 160-168, 2010.

HANNA, G. Some pedagogical aspects of proof Interchange. v. 2, n 1, pp. 6-13, 1990. KO, Y. et al; Validating proofs and counterexamples across content domains: Practices of importance for mathematics majors. The Journal of Mathematical Behavior, v. 32, n 1, pp. 20-35, 2013.

LIBÂNEO, J. F. O; OLIVEIRA, J. F.; Toschi, M. S. Educação escolar: políticas, estrutura e organização, 10 Ed. São Paulo: Cortês, 2012.

LUCKESI, C. C. Avaliação da Aprendizagem Escolar. 1. Ed. São Paulo: Cortês, 2011.

LIPMAN, M. Critical Thinking: What can it be? Analytic Teaching: v.8, n 1, 2014. 
Disponível em $<$ http://libservices.viterbo.edu/journal/ojs/index.php/at/article/view/403 $>$

Acesso em 15 de janeiro de 2017.

LIPMAN, M. O Pensar na Educação. Trad. Anna Mary Fighier Perpetuo, 1 Ed.

Petrópolis: Vozes, 1995.

MACHADO, N. J. Ensaios Transversais: Cidadania e Educação. São Paulo:

Escrituras, 1997.

MARIČIĆA, S.; ŠPIJUNOVIĆB, K., Developing; Critical Thinking in Elementary

Mathematics Education through a Suitable Selection of Content and Overall Student

Performance. Social and Behavioral Sciences, v. 180, 2014, pp. 653-659.

MINAKOVA, L. Y.; Critical Thinking Development in Foreign Language Teaching for Non-language-majoring Students. Social and Behavioral Sciences, v 154. 2014, pp. 324 328.

MORTARI, C. A. Introdução à Lógica.1 ed. São Paulo: Ed. UNESP: Imprensa Oficial do Estado, 2001.

PEREIRA, E., MARTINS, J. F., ALVES, V. S., DELGADO, E. I., A contribuição de John Dewey para a educação. Revista Eletrônica de Educação, v. 3, n. 1, 2009, pp. 154 - 161. Disponível em: <http://www.reveduc.ufscar.br> Acesso em 27 de março de 2017.

RICHARD, P.; Critical thinking, Fundation for critical thinking. Foundation for Critical Thinking, 2012 Disponível em <www.criticalthinking.org>. Acesso em março de 2016.

SEVERINO, A. J. Educação, Trabalho e Cidadania: A Educação Brasileira e o desafio SILVA, E. R. O Ponto de Partida Para a Argumentação: O Desenvolvimento do Senso Crítico. 1 Ed. São Paulo: Cabral Editora Universitária, 2000.

SUMNER, W. G. FOLKWAYS: $\boldsymbol{A}$ Study of the Sociological Importance of Usages, Manners, Customs, Mores, and Morals, New York: Ginn and Co., 1940.

SKOVSMOSE, O. Educação Matemática Crítica: A questão da Democracia.

Tradução: Abigail Lins, Jussara de Loyola Araújo. 6 Ed. Campinas, SP: Papirus, 2013. SKOVSMOSE, O. Um Convite à Educação Matemática Crítica. Tradução: Orlando de Andrade Figueiredo. 1 Ed. Campinas, SP: Papirus, 2014.

SKOVSMOSE, O., Cenários para investigação. Revista Bolema, nº 14, pp. 66 a 91, 2000. UDI, A. E.; AMIT, M.; Developing the skills of critical and creative thinking by probability Teaching. Social and Behavioral Sciences. v. 15, 2011, 1087-1091. ZABALA, A. Enfoque Globalizador e Pensamento Complexo - Uma proposta para o currículo escolar. Trad. Ernani Rosa. 3 Ed. Porto Alegre: ARTMED, 2002. 